Historic, Archive Document

Do not assume content reflects current scientific knowledge, policies, or practices. 

$62,2,3$

ALPHA NURSERY

H. G. WIRT, Proprietor

ALPHA, ILLINOIS

S6:

JAN 301928 t

36 Years

of Good

Service

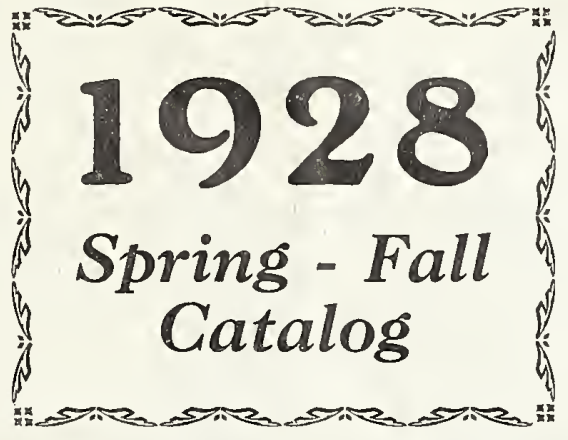

40 Acres

Trees - Small Fruits

Shrubs - Plants

and Bulbs

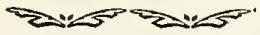

Wirt's Quality Roses, Shrubs, Trees, Fruits, Plants and Seeds SAVE YOU MONEY

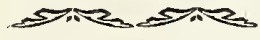

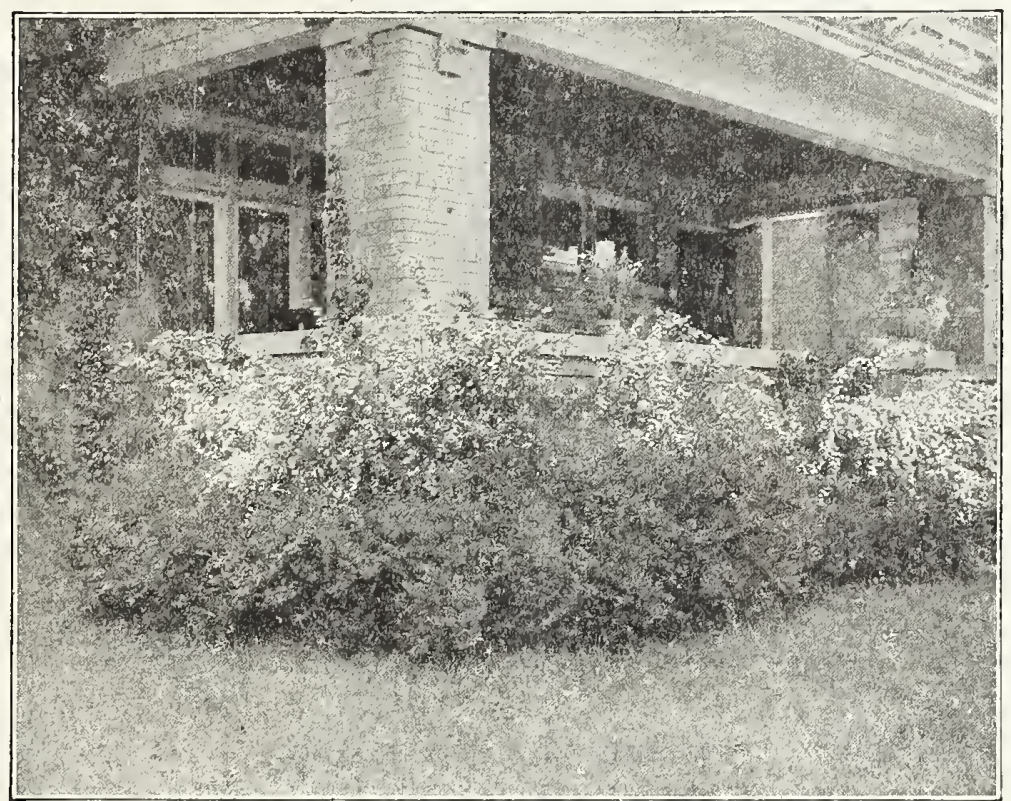

5 Spirea Van Houttei and 10 Jap Barberry in this planting.
20

Wirt's Quality Roses, Shrubs, Trees, Fruits, Plants and Seeds SAVE YOU MONEY

$\sin 5 \times$ See special offer below

\section{Special Offer}

This special offer of shrubs will fix up a corner in your yard or around your porch.

\section{Spirea Van Houttei, $4 \mathrm{ft}$. tall
10 Jap. Barberry, 18-24 in. tall \\ The 15 Shrubs by express \\ Prepaid for only}

These shrubs will give effect at once as they are nice, large, bushy plants, you don't have to wait until they grow. They are direct from the nursery to you.
I have added a seed department to my business. Try Wirt's Corn Belt Seeds. 


\section{Come and See Us}

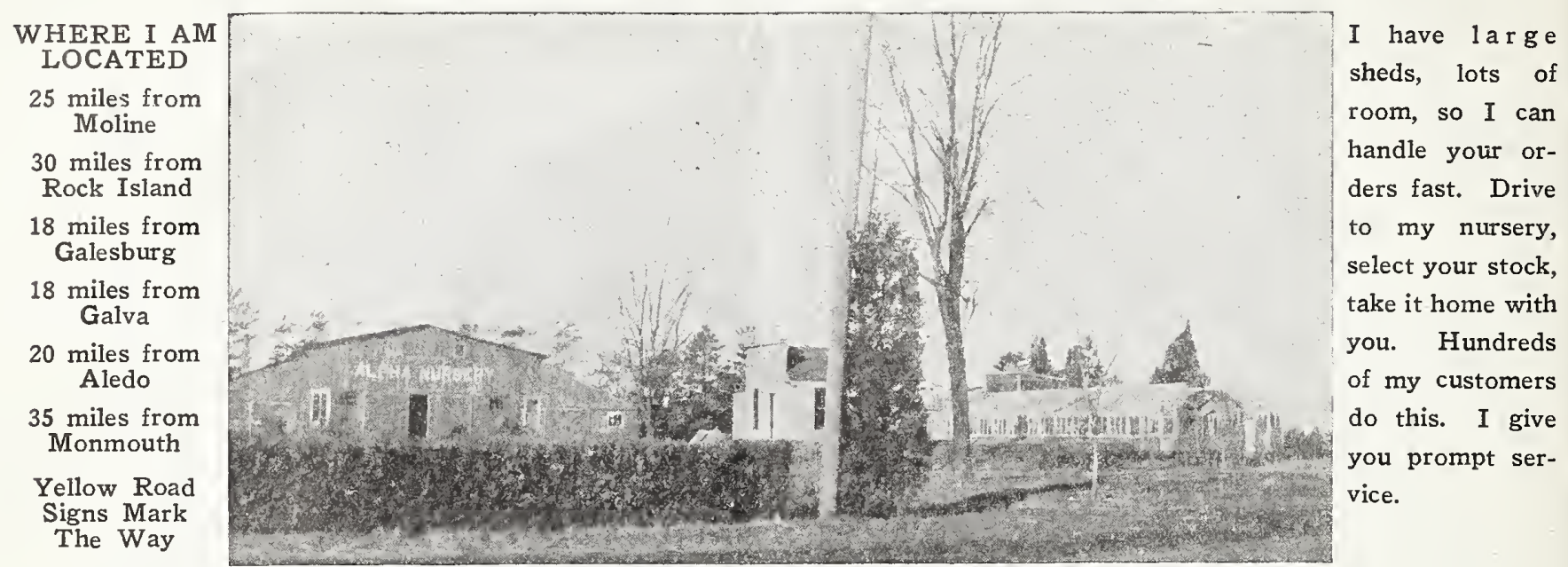

Greenhouse and Packing Sheds

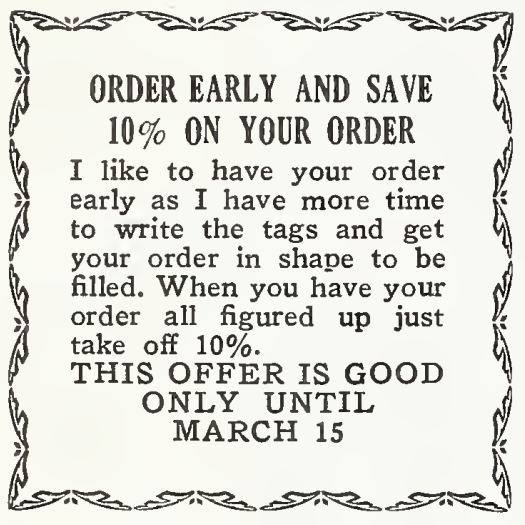

\section{Write}

your name and address plainly. If the shipment goes to a different town, make it plain.

\section{How to Send Money}

Post office order.

Express order.

Draft.

Check.

Cash by registered mail (only).

\section{Shipping Time}

SPRING: Shipping starts the last week in March and continues until June 1st.

FALL: Shipping starts about October 1 st and continues until freezing weather.

\section{Disease}

The nursery is inspected each year by the state, and a certificate of inspection goes with each order.
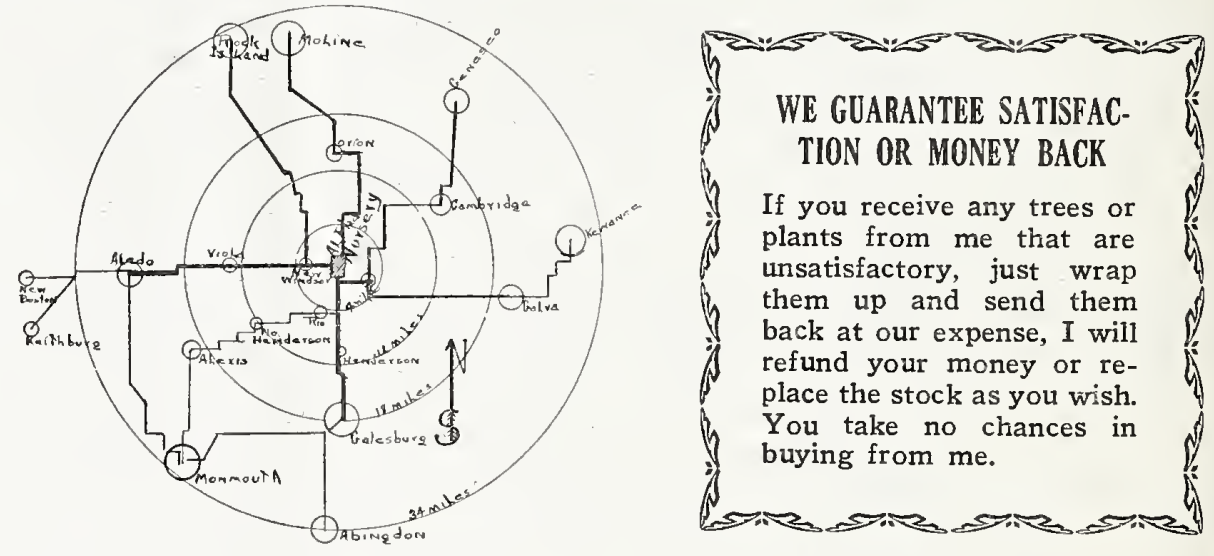

\section{Parcel Post}

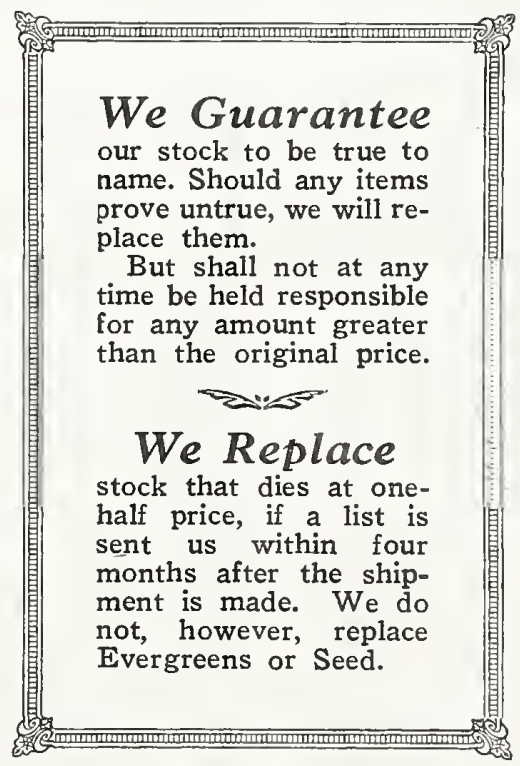

I can send packages up to $50 \mathrm{lbs}$. and which are not more than 84 in. in length and girth by mail. This is a cheap and quick way for small packages going a few hundred miles. Large fruit trees, shade trees, evergreens, etc., cannot go by mail. Don't forget to include postage if not postpaid.

\section{Express}

All large orders, such as trees, large shrubs, large orders of berry plants should go by Express. It is cheaper than mail, and much quicker than freight. Nursery stock will not stand delay in transit.

\section{Freight}

Should be used only in short hauls of large orders of fruit or shade trees, and never used on berry plants or perennials. It takes too long. 


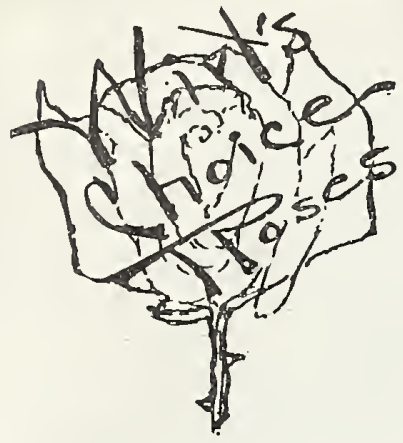

\section{ROSES Are Easy to Grow}

\section{Sturdy 2 year
Plants $50^{c}$.}

Plant more Roses. They will bloom the first year. Many of my customers have cut from 15 to 30 blooms from a plant the first year.

State Varieties Wanted

\begin{tabular}{c|c|c|c|c}
\hline Size & Each & 3 Plants & 5 Plants & 10 Plants \\
\hline $\begin{array}{c}\text { Sturdy } 2 \mathrm{yr} . \\
\text { Postage }\end{array}$ & $\$ .50$ & $\$ 1.45$ & $\$ 2.35$ & $\$ 4.50$ \\
\hline
\end{tabular}

\section{HYBRID PERPETUAL ROSES} EVERBLOOMING

American Beauty-Crimson perfect buds. Frau Karl Druschki-Pure White, long perfect buds.

Gen. Jacqueminot-Bright crimson. Fine bloomer.

\section{TEA ROSES \\ EVERBLOOMING}

Columbia-Bright pink, long stems and perfect buds.

Etoile de France-Vivid crimson. Very showy.

Gruss an Teplitz-Crimson. One of our best bloomers.

K A Victoria-White. Buds on long stems. Fragrant.

Lady Hillington-Deep Yellow fine long buds.

Los Angeles-Flame Pink Shaded Gold. One of the best.

Mrs. C. W. Miller-Large Rosey salmon.

Mme. C. Testout-Satiny pink rose. Fine quality.

Red Radiance-Deep red. One of the new sorts.

Souv. Claudius Pernet-Pure bright Yellow. Very fine.

Sunburst-Bright Orange. Long pointed buds.

\section{BABY ROSES}

\section{EVERBLOOMING}

Baby Dorothy-Bright pink, very showy.

Crimson Baby-Crimson, always in bloom.

Gruss an Auchin-Light yellow, only yellow baby.

\section{INSTRUCTIONS FOR PLANTING AND CARE OF ROSES}

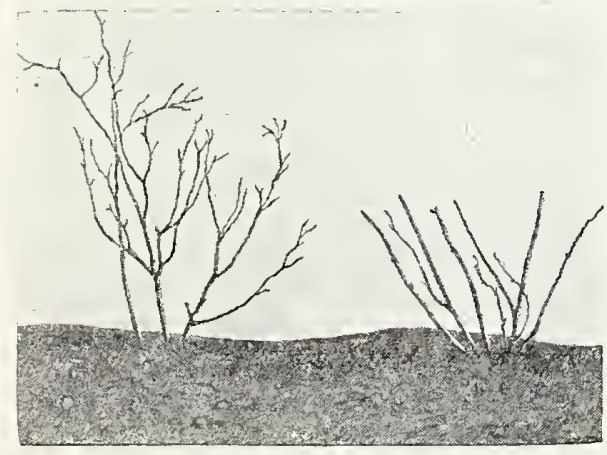

Roses before trimming.

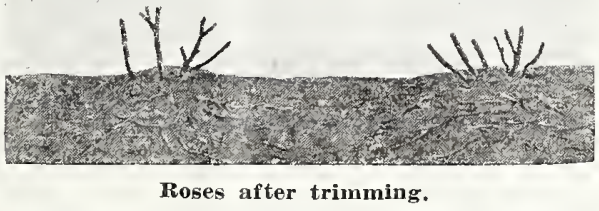

The growing of roses is very simple, the planting and trimming is the main thing.

Roses should be planted 3 to 4 inches deeper than they grew in the nursery, get them down well into the ground. Fill the hole about half full of soil then put at least one bucket of water to each .plant, after the water settles fill up the hole with soil as a fertilizer a little well rotted cattle manure can be used on top the ground. After the rose is planted cut the plant back within 4 inches of the ground. For winter cut the plants back within 6 inches of the ground and cover the plant completely with leaves or straw. In early spring remove the covering and cultivate and lightly fertilize, and you will have roses every year.
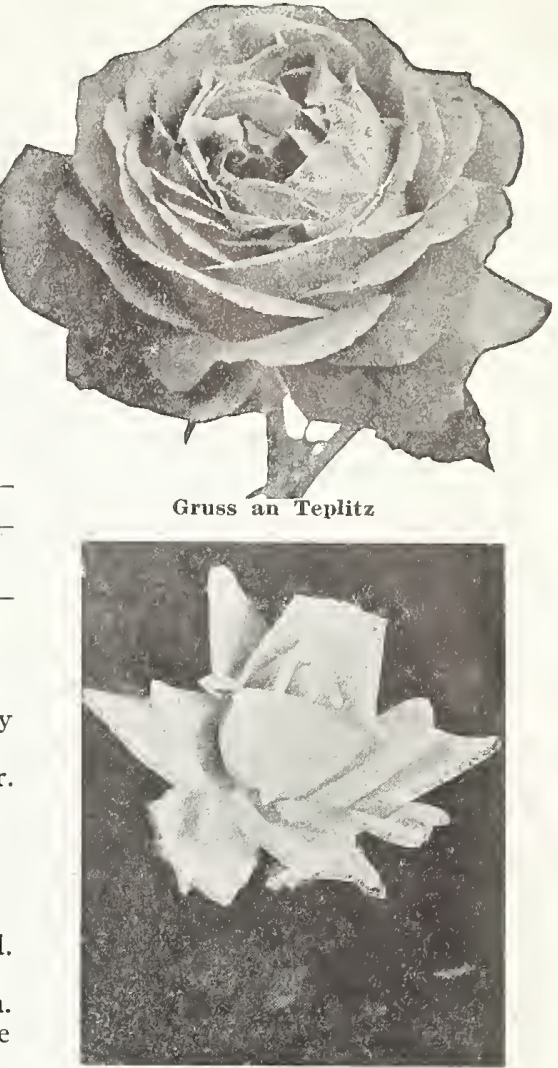

Columbia
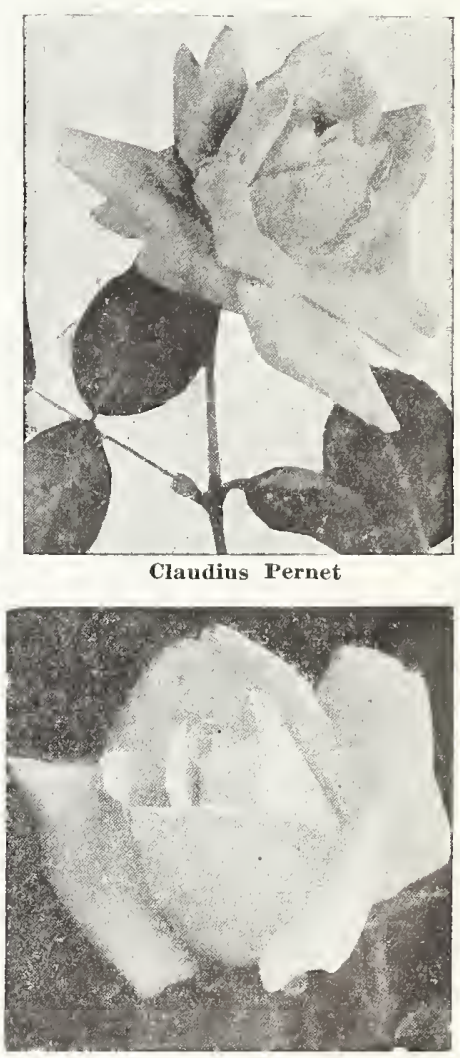

Frau Karl Drusehki 


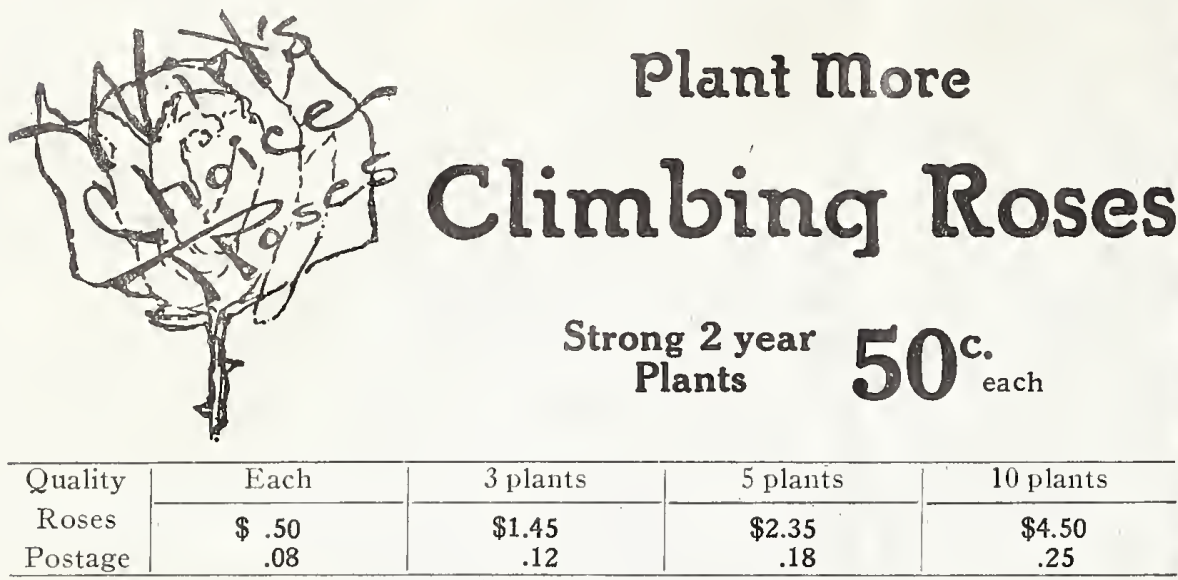

Hardy Climbing Roses need only a foothold, and the long trails will twine and cling to any little trellis assistance and spread charming clusters over yards of wall space.

Climbing roses bloom the second year. They bloom on the wood that is one year old, so don't trim off last year's growth. They like a sunny place, and good

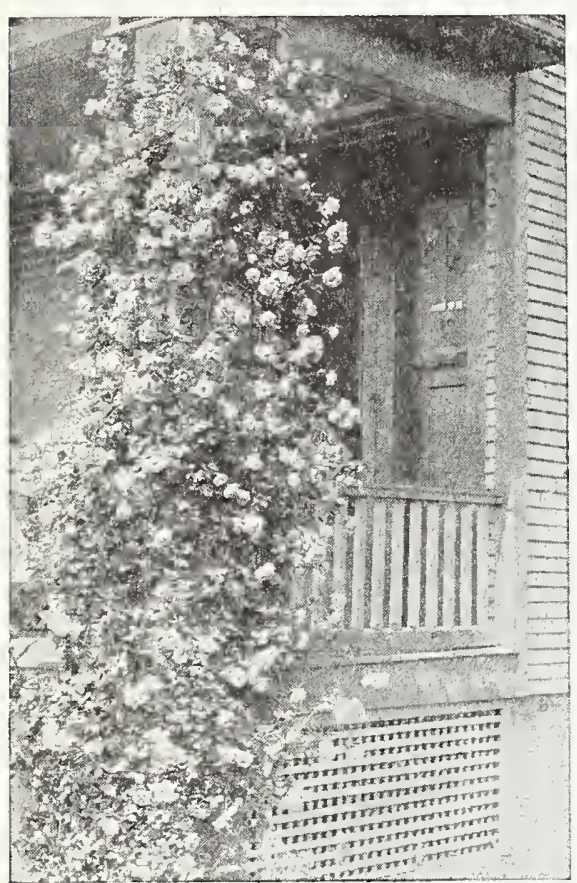
rich soil. Spray with Black Leaf 40 for the rose bugs and lice. Black Leaf 40-1 oz. 35 cents. Cannot Mail.

Excelsa-(Red Dorothy Perkins)-A radiant, blood-red cluster rose. The clusters are very large and fairly cover the vines. It is best to plant this variety where crimson rambler is not hardy.

Climbing American Beauty-Much like the bush form of this name, except it has the climbing habit.

Dorothy Perkins-Beautiful shell pink, full and double. Large size for a cluster rose; it is a hardy, strong grower.

Prairie Queen-The flowers are very large and of peculiar globular form; bright, rosy red; changing to lighter as the flower opens. Of strong, rapid growth.

Multiflora Rose-Double, pink; strong grower; very hardy; profuse bloomer. Good where shade is wanted, also where other Roses fail to grow.

Crimson Rambler-It is a vigorous grower; flowers glowing and produced in immense panicles.

Paul's Scarlet Climber-Winner of gold medal as best new climbing Rose, at National Rose Society's Exhibition. Flowers are scarlet, shaded crimson; large, semi-double. Corresponds with Cl. Am. Beauty, Dr. Van Fleet, etc., as to size, shape and habit. Blooms very long, holding in flower after many June bloomers have dropped their petals; a wonderful Rose for trellis or pergola use.

Gardenia-One of the best yellow climbers; very hardy and strong grower.

Gold Finch-A fine yellow climber. The flowers are good form and fragrant.

Paul's Scarlet

\section{Hardy Roses for Landscaping}

This is a miscellaneous group of Roses that is very hardy and can be used for lawn or cemetery planting. Will stand lots of wear and tear and still keep on blooming. Hugonis-Is a beautiful golden Rose, blooms especially early. Flowers small and dainty. Buds form about the first week in April and should be in full bloom the first week in May. 90c each; 3 for $\$ 2.50$.

Rugosa Rose-A single red rose, blooming at intervals thru the summer. Used more as a shrub. Has dark, rich foliage, oddly wrinkled and remarkably free from insects. Is absolutely hardy. 2 yr. plants $50 \mathrm{c}$ each.

MEMORIAL ROSE-Beautiful, fragrant, single, pure white flowers. Handsome for covering rockeries, mounds or embankments, especially valuable for evergreen cemetery planting, 2 yr. plants $60 \mathrm{c}$ each: 3 for $\$ 1.50$.

\section{Eskimo Beauties}

\section{"THE KIND THAT WILL GROW WHERE NO OTHERS WILL,}

Once planted, they are permanent: no pruning, no spraying, no suckering nor anything else is needed-just a little manure spaded in and the ground stirred. They bloom all summer. 2 yr. plants $50 \mathrm{c}$ each.

Conrad F. Meyer-(An Eskimo Beauty)-The blooms are large and full, the petals gracefully in-curved. Bright, clear, lively pink.

Hansa-(An Eskimo Beauty)-Handsome in bud and bloom. Both are large, very full and double. The color is rich, maroon-red. 


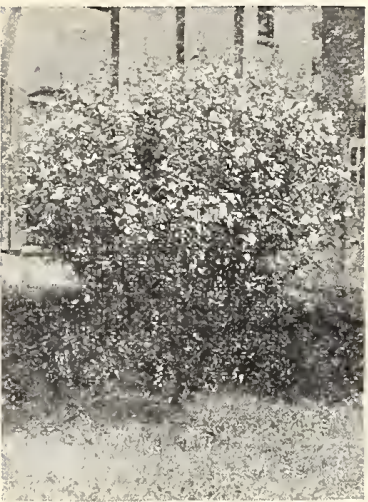

Althea

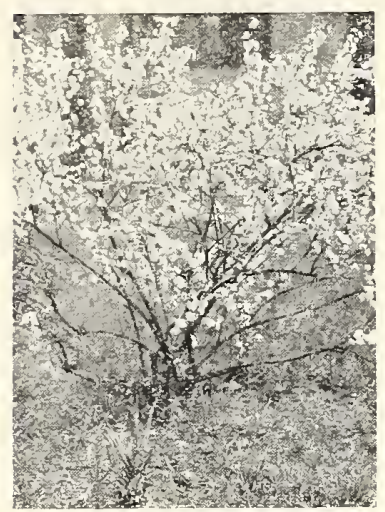

Flowering Almond

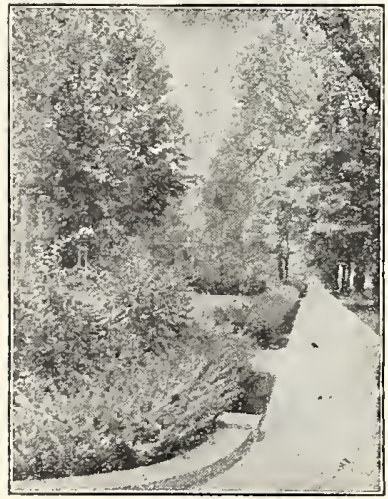

Barberry Japanese

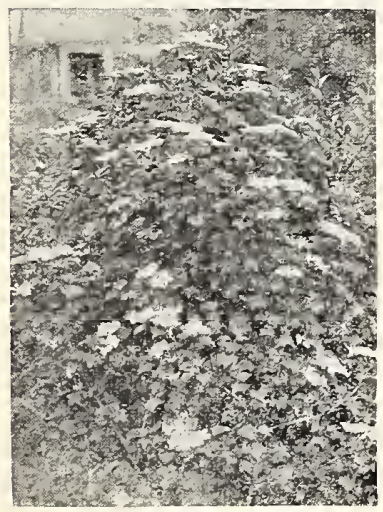

Cranberry Highbush

\section{WIRT'S HARDY SHRUBS}

\section{make the Home Attractive}

A little shrubbery planted around the home makes it attractive and increases the value. The cost of the plants is small. I list only the good varieties, the ones that you can feel safe in planting. They are all good size, no little runts, but good strong plants.

\section{ALTHEA}

Rose of Sharon-Grows 3-4 ft. Blooms in Aug. and Sept. and are the beauty spots of the fall as Lilacs are in the spring. Your selection of Colors: Red, White, Pink and Purple. 2-3 ft. plants 50c each; 3 for $\$ 1.40$.

\section{ALMONDS}

Pink-Grows 4-5 ft. Blooms from roots clear to the tips of the branches, just covered with small pink rose like flowers early in May. 2-3 ft. plants 50c each; 3 for $\$ 1.40$.

White-Same as above but the blooms are white. $2-3 \mathrm{ft}$. plants $50 \mathrm{c}$ each; 3 for $\$ 1.40$.

\section{BARBERRY THUNBERGII}

Japanese Barberry-Grows 3-4 ft. Much used for hedges and foundation planting, foliage turns red in fall, with red berries that hang on all winter. Does not have wheat rust. $18-24$ in. plants $35 \mathrm{c}$ each; 3 for $\$ 1.00$.

\section{VIBURNUM OPULUS}

Cranberry Highbush-Grows 6-8 ft. Foliage lustrous green changing to rich copper in fall. Blooms white in May followed by scarlet berries. $18-24$ in. plants 60 c each. 3 for $\$ 1.70$.

\section{CALYCANTHUS}

Sweet Scented Shrub-Grows 5-6 ft. Called by many Allspice. Blooms in June chocolate colored flowers and of delightful fragrance. Foliage heavy and leathery looking. 18-24 in. plants $60 \mathrm{c}$ each; 3 for $\$ 1.70$.

\section{FORSYTHIA}

Golden Belle Upright-Grows 4-6 ft. Flowers yellow very early in spring, before the leaves come out, erect grower. 2-3 ft. plants $50 \mathrm{c}$ each; 3 for $\$ 1.40$.

Golden Belle Weeping-Same as above but of weeping habit. 50 c each; 3 for $\$ 1.40$.

\section{ELDER}

Golden-Grows 6 to $8 \mathrm{ft}$. This is one of the finest golden leaved shrubs. The leaves turn about mid-summer. White flowers. 2-3 ft. plants 50c each; 3 for $\$ 1.40$.

\section{DEUTZIA}

Pride of Rochester-Grows 4-5 ft. Has large double white flowers in May. One of the standard Deutzias. $2-3 \mathrm{ft}$. plants $50 \mathrm{c}$ each. 3 for $\$ 1.40$.

Lemoine-Grows 3-4 ft. Large pure white flowers borne in cone shaped heads. Dwarf habit. $18-24$ in. plants $50 \mathrm{c}$ each; 3 for $\$ 1.40$.
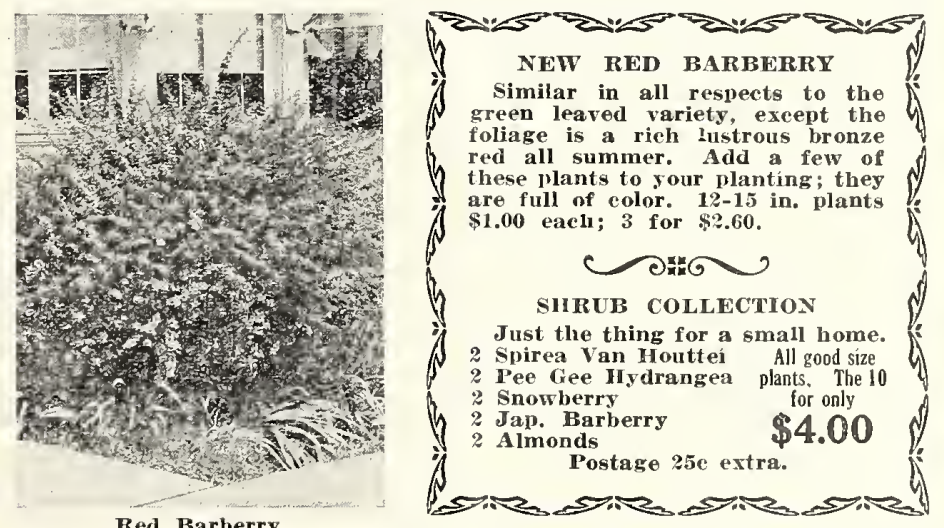

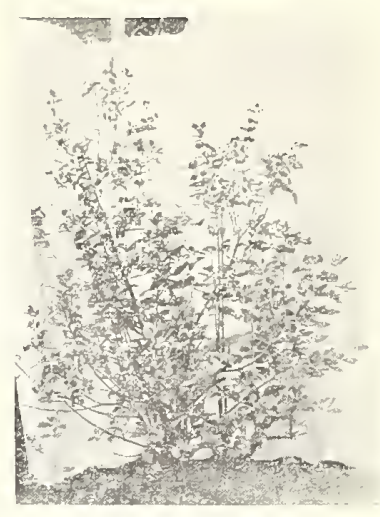

Calyeanthus

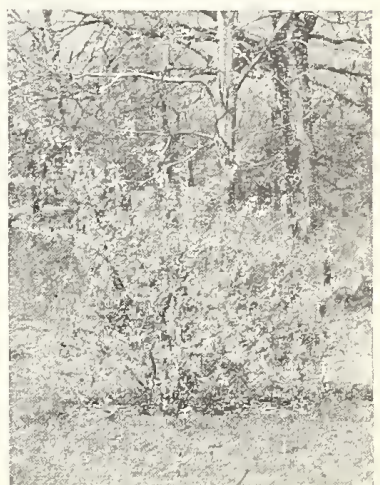

Golden Belle

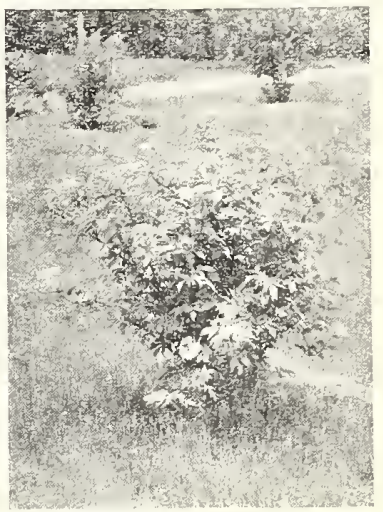

Golden Elder

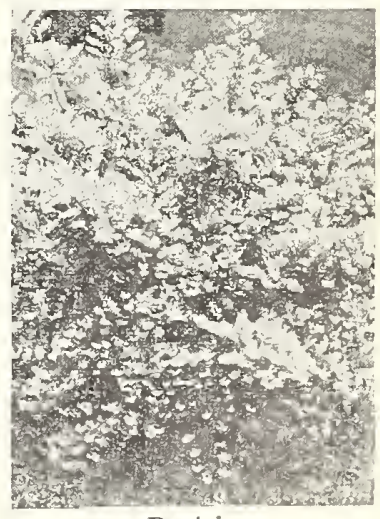

Deutzia 


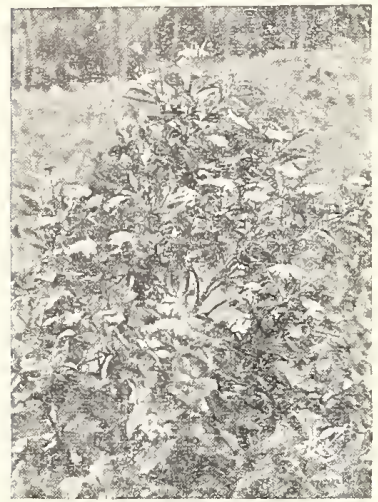

Dogwood Red

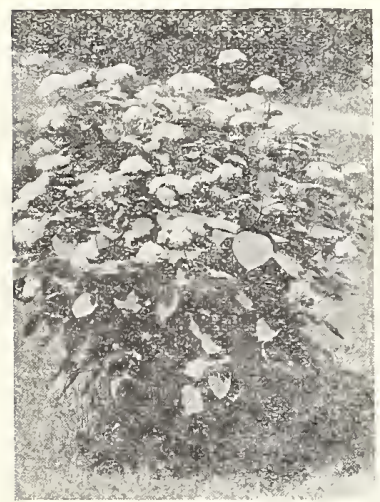

Hills of Snow

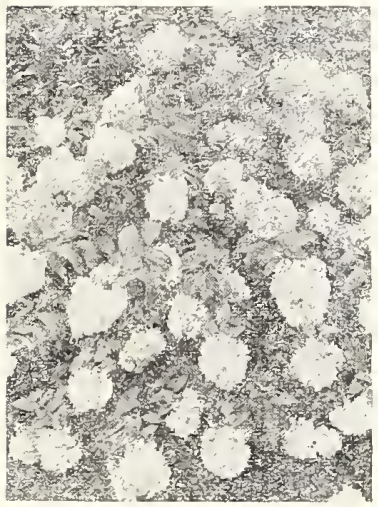

Hydrangea-Pee Gee

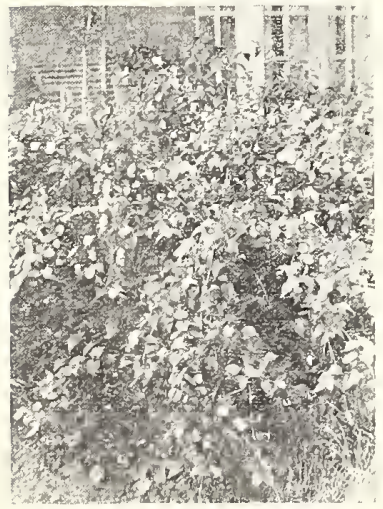

Kerria
WIRT'S HARDU SHRUBS

\section{DOGWOOD}

Siberica-(Coral Red)-Grows 6 to $8 \mathrm{ft}$. This is the one with the bright red branches and I think the best. White flowers in the summer, followed by berries. 3-4 ft. plants 50c eash; 3 for $\$ 1.40$. Yellow Barked-Grows 4-5 ft. This shrub has yellow branches. Make a beautiful show when planted in front of the red. $2-3 \mathrm{ft}$. plants $50 \mathrm{c}$ each; 3 for $\$ 1.40$.

\section{HYDRANGEA}

Summer Hills of Snow-Grows 3-4 ft. Blooms from July until frost, round large white flowers on long stems, changing to green. A very popular foundation shrub. $12-18$ in. plants $50 \mathrm{c}$ each; 3 for $\$ 1.40$. $12-14$ in. plants $35 \mathrm{c}$ each; 3 for $\$ 1.00$.

Pee Gee Hydrangea-Grows 4-5 ft. This is the hydrangea that has the large cone slape flowers white in August, turn pink later in fall. One of the best shrubs. $18-24$ in. plants 50c each; 3 for $\$ 1.40$. $2-3 \mathrm{ft}$. plants $75 \mathrm{c}$ each; 3 for $\$ 2.00$. $12-14$ in. plants $35 \mathrm{c}$ each; 3 for $\$ 1.00$.

\section{KERRIA}

White-Grows 4-6 ft. Bright green foliage, single white flowers in June, followed by black berries. $2-3 \mathrm{ft}$. plants $50 \mathrm{c}$ each; 3 for $\$ 1.40$. Yellow-Grows 3-4 ft. Foliage deep green. Branches vivid green all winter. Yellow flowers in June. 18-24 in. plants $59 \mathrm{c}$ each; 3 for $\$ 1.40$.

\section{LILAC}

Common Purple-The old time sweet scented purple lilac. 3-4 ft. plants 50c each; 3 for $\$ 1.40$.

White-Same as above but white flowers. 50c each; 3 for $\$ 1.40$.

\section{FRENCH LILACS}

Pres. Grevy-Deep blue double and extra fine lilac. 18-24 in. plants 80 c each; 3 for $\$ 2.10$.

Ludwig Spaeth-Single dark red, the best of the red 1ilacs, somewhat dwarf. 18-24 in. plants 80c each; 3 for $\$ 2.10$.

Mad. Lemoine-Pure white double. $80 \mathrm{c}$ each; 3 for $\$ 2.10$.

\section{SYRINGA}

Everblooming (Virginal)-Grows 5-6 ft. This is one of the new varieties, flowers semi-double white. Blooms almost all summer. This is something new and different. 18-24 in. plants $75 \mathrm{c}$ eash; 3 for $\$ 2.10$.

Mock Orange-Grows 6-8 ft. This is the old fashioned sweet scented syringia. $2-3 \mathrm{ft}$. plants $50 \mathrm{c}$ each; 3 for $\$ 1.40$.

\section{SNOWBERRY}

White-Grows 3-4 ft. Bears large clusters of white waxy berries in the fall, very showy. 2-3 ft. plants $50 \mathrm{c}$ each; 3 for $\$ 1.40$.

Red (Coral Berry)--Has small red berries, very attractive. Both varieties will grow almost anywhere. 2-3 ft. plants 50c each; 3 for $\$ 1.40$.

\section{SNOWBALL}

Common Snowball-Grows $6.8 \mathrm{ft}$. This is the old fashioned snowball that grows almost everywhere and flowers in May with large white balls. $18-24$ in. plants $60 \mathrm{c}$ each; 3 for $\$ 1.70$.

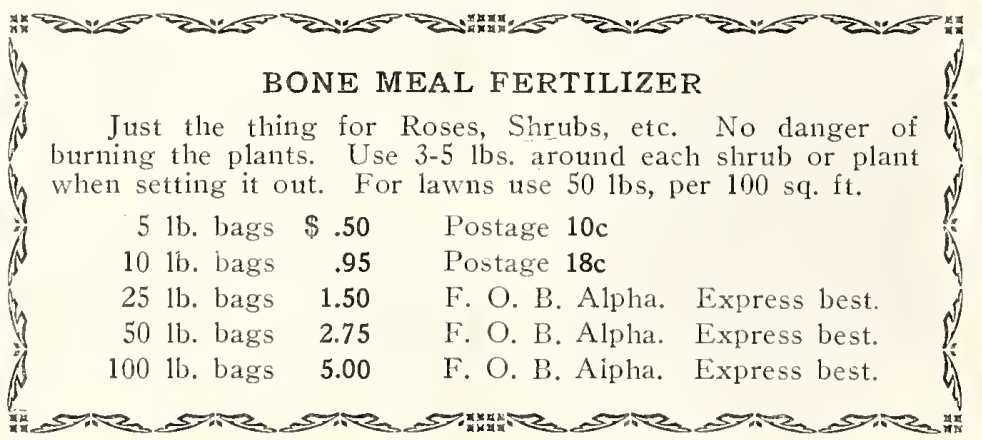

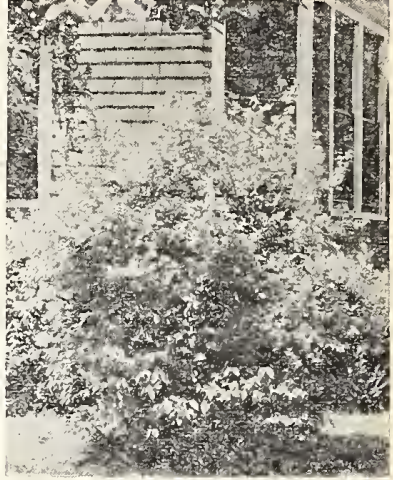

Lilac

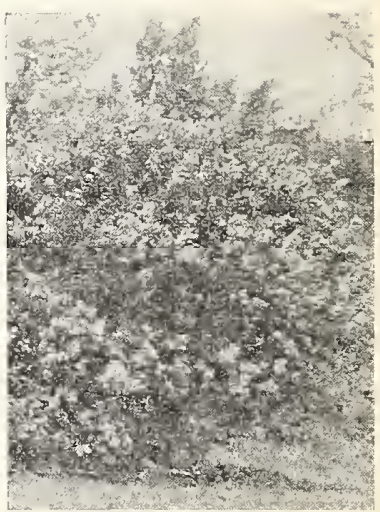

Syringa

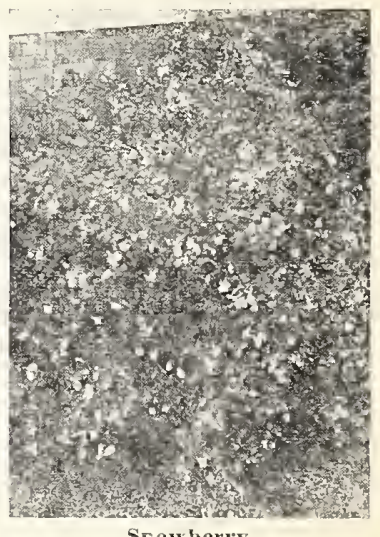

Srawber'y

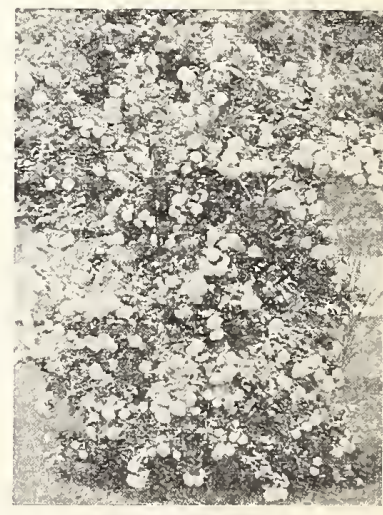

Snowball 


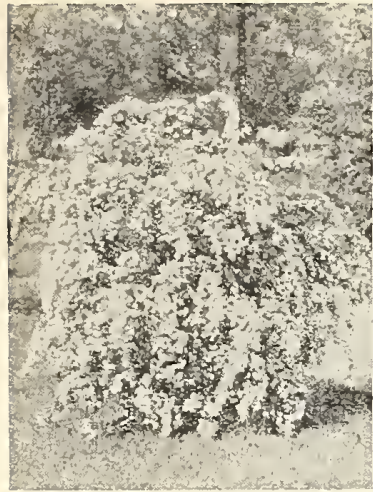

Spirea Van Houttei

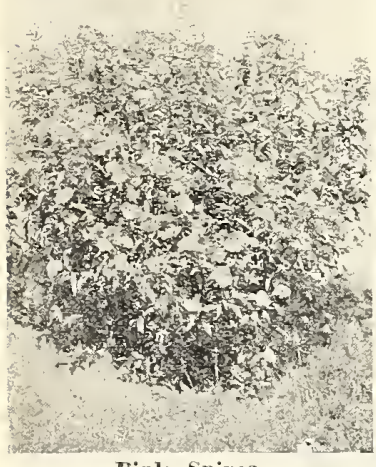

Fink Spirea

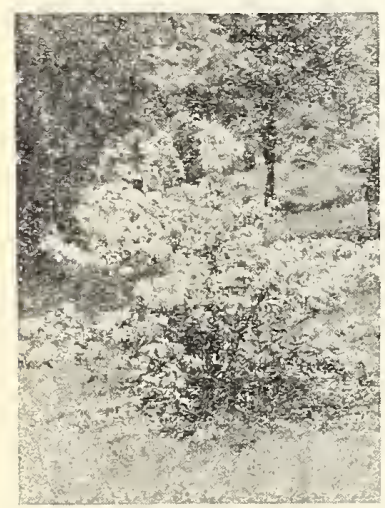

Weigelia

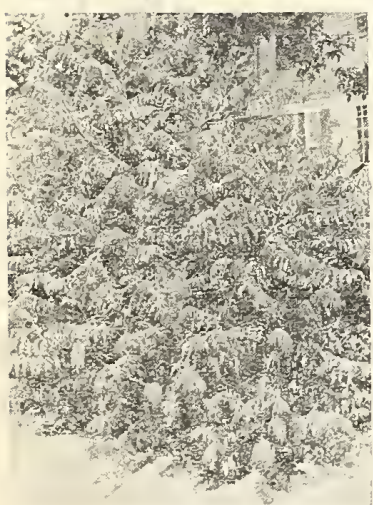

Sumac

\section{WIRT'S HARDY SHRUBS}

\section{SPIREAS}

Spirea Van Houttei (Brical Wreath)-Grows 4-6 ft. The most popular shrub planted, bush is just covered with pure white flowers in May. 3-4 ft. plants 50c each; 3 for $\$ 1.40 ; 6$ for $\$ 2.70$.

Spirea Ant Waterer-(Pink Spirea. Grows 2-3 ft.) Flowers reddish purple, borne flat on end of stems. Blooms all summer. 12-18 in. plants $50 \mathrm{c}$ each; 3 for $\$ 1.40 ; 6$ for $\$ 2.70$.

Spirea Frobellia (Pink Spirea)-Grows a little taller than above. Flowers the same, but the foliage turns reddish purple in the fall very beautiful. $18-24$ in. plants 50 c each; 3 for $\$ 1.40 ; 6$ for $\$ 2.70$.

Spirea Bumulda (Pink Spirea)-Same as above, but flowers light pink. Foliage turns dark in fall. 50c each; 3 for $\$ 1.40$; 6 for $\$ 2.70$. Spirea Thunbergii-Grows 3-5 ft. Blooms early in May with small white flowers, Foliage very fine cut. A fine low growing shrub. 18-24 in. plants 50c each; 3 for $\$ 1.40$.

Spirea Billardi-Grows 4-5 ft. Pink flowers borne on long spikes in August. Bush upright grower. 3-4 ft. plants 50c each; 3 for $\$ 1.40$. Spirea Golden-Grows 5-6 ft. White flowers in June. Foliage turns yellow in early fall. 3-4 ft. plants $50 \mathrm{c}$ each; 3 for $\$ 1.40$.

\section{SUMAC}

Cut Leaf Sumac-Grows 6-8 ft. Fern like foliage, turning bright red in fall. One of the most attractive tall shrubs. 2-3 ft. plants 50 c each; 3 for $\$ 1.40$.

Smooth Sumac-Grows 8-10 ft. Makes a small tree with beautiful leaves which turn copper color in fall. 4-5 ft. plants $50 \mathrm{c}$ each; 3 for $\$ 1.40$.

\section{WEIGELIA}

Rosea Weigelia-Grows 3-5 ft. Beautiful heavy foliage. Pink flowers in June with a few all summer. 18-24 in. plants 50c each; 3 for $\$ 1.40$.

Eva Rathke Weigelia-Grows 3-5 ft. Red trumpet shaped flowers all summer. A very attractive shrub. $18-24$ in. plants $60 \mathrm{c}$ each; 3 for $\$ 1.70$.

\section{HONEYSUCKLE}

Morrowi-Grows 6-8 ft. One of the best tall shrubs. Light pink flowers, followed by red berries, upright grower. $3-4 \mathrm{ft}$. plants 50c each; 3 for $\$ 1.40$.

Tartarian-Grows 5-6 ft. Bush of spreading habit flowers creamy white, followed by black berries. $2-3 \mathrm{ft}$. plants $50 \mathrm{c}$ each; 3 for $\$ 1.40$. Fragrant-Grows 3-5 ft. Almost an evergreen foliage. Dark green, which hangs on almost all winter. $2-3 \mathrm{ft}$. plants $50 \mathrm{c}$ each; 3 for $\$ 1.40$.

\section{QUINCE}

Japan Quince-Grows 4-5 ft. Flowers very abundant in early spring. Brilliant scarlet crimson. $14-18$ in. plants $50 \mathrm{c}$ each; 3 for $\$ 1.40$.

\section{PRIVET}

Ibota-Grows 4-5 ft. Habit of growth a little spreading dark green foliage. Fine for shady places or tall screens and hedges. $2-3 \mathrm{ft}$. plants 30c each; 6 for $\$ 1.70 ; 10$ for $\$ 2.50$.

Amour River-Grows 5-6 ft. This is the popular hedge. Privet. 2-3 ft. heavy plants fine for replacing in hedges $25 \mathrm{c}$ each any amount. See page 9 for hedge sizes.

\section{ACACIA}

Rosea-Grows 4-5 ft. Locust like leaves with pink locust like flowers, an unusual shrub. $3 \mathrm{ft}$. plants $50 \mathrm{c}$ each; 3 for $\$ 1.40$.

\section{ARALIA}

Aralia Pentephylla-Grows 4-5 ft. Pea green foliage. Fine shrub for screen or shrubbery border. 3-4 ft. plants $40 \mathrm{c}$ each; 3 for $\$ 1.10$.

\section{TAMARIX}

Hispida-Grows 6-8 ft. Grecn foliage, very fine and feathery. Has soft pink sprays of flowers in July and August. 2-3 ft. plants 50c each; 3 for $\$ 1.40$.

Amurensis-Grows 5-6 ft. Blueish green foliage with the feathery effect. The flowers are a pinkish red color. 50c each; 3 for $\$ 1.40$.
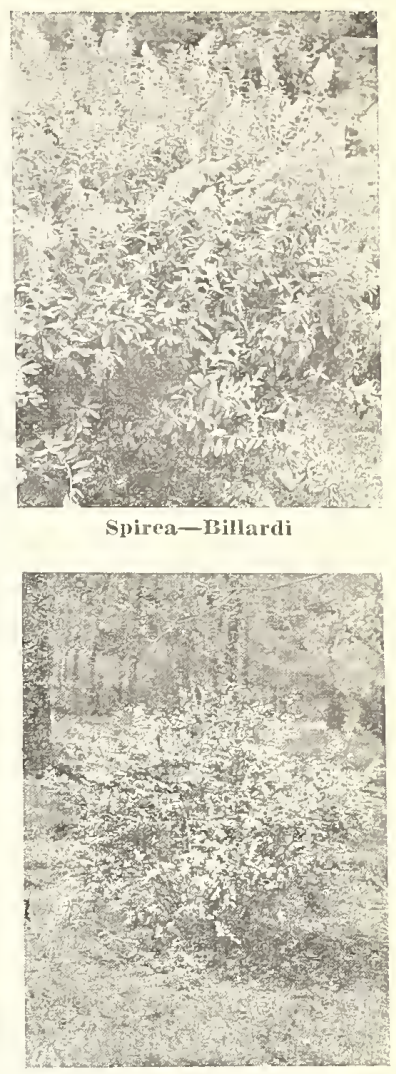

Spirea Thunbergii

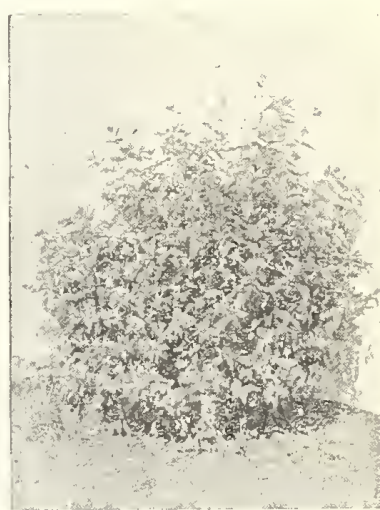

Honeysuckle

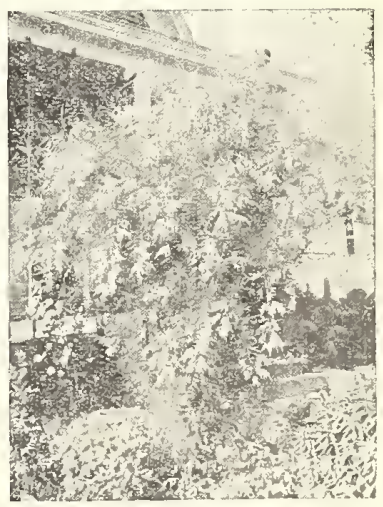

Tamarix 


\section{Strong 2 year Plants \\ Wirt's Hardy Vines $35_{\text {asch }}^{\text {c. }}$}

Honeysuckle, Scarlet Trumpet-One of the handsomest in cultivation; coral flowers; very vigorous and hardy; blooming all summer.

Trumpet Vine (Tecoma Radicans)-Handsome, dark green foliage and showy clusters of orangc and scarlet flowers during the summer.

Dutchman's Pipe (Sipho)-A strong growing vine, with immense heart-shaped leaves and peculiar pipe-shaped flowers. This vine makes a fast, heavy growth, and is fine for the porch or trellis. Hardy. These plants are grafted from a blooming plant therefore are sure to bloom. $\$ 1.00$ each.

Bittersweet-A native vine that is especially ornamental in fall and winter, with brilliant orange and scarlet fruit.

Chinese Matrimony Vine-A strong, hardy climbing vine.
Bright, rosy-purple flowers, followed by brilliant scarlet berries.

Wisteria (Purple)-One of the finest climbers, of rapid growth, and perfectly hardy, with long, pendulous clusters of bluish purple. Flowers in June.

Engleman's Ivy-It is one of the finest ivies we have. The brilliant coloring of the leaves in autumn, together with perfect hardiness, makes it a valuable climber for covering brick or stone walls. Where hardiness is necessary, the Engleman will be found much superior to Boston ivy.

American Ivy-The well known native vine with five parted leaves, that change to rich crimson in autumn; berries blue black; very rapid grower and perfectly hardy.

Boston Ivy-Should be planted on the North side of the building, clings to brick stucco or stone. $2 \mathrm{yr}$. plants $60 \mathrm{c}$ each; 3 for $\$ 1.70$.

Postage on all Vines on this page, $6 \mathrm{c}$ for 1 to 3 plants; $8 \mathrm{c}$ for 3 to 6 plants.

\section{CLEMATIS}

Jackmanni-The well known purple flowering clematis. Flowers 4 to 6 inches across.

2 yr. Field Grown plants $75 \mathrm{c}$ each.

Pot plants, 2 yr. 60c each.

Henryii-The large white flowering clematis.

2 yr. Field Grown plants $75 \mathrm{c}$ each.

Pot Plants, 2 yr. 60c each.
Mme. Edw. Andre-A robust plant blooming freely. Violet red flower 3 to 4 inches across. 2 yr. Field Grown plants $75 \mathrm{c}$ each, Pot plants, 2 yr. 60c each.

Paniculata-The small flowering sweet scented white cle. matis. One of the most vigorous and beautiful climbers. 2 yr. Field Grown plants $50 \mathrm{c}$ each.

Pot Plants, 2 yr, 40c each.

Our pot plants are grown in the Greenhouse and shipped with a ball of earth, and those that cannot get field plants to grow are having fine success with my pot plants.

\section{FALL BULBS}

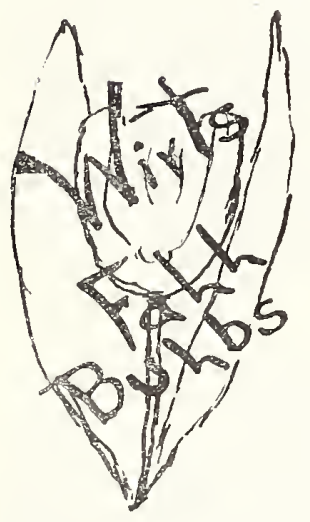

I offer the following bulbs for fall planting. These bulbs come from Holland and I receive them so they can be planted early in September.

\section{TULIPS}

Darwins-The long stem tulips. Mixed colors $50 \mathrm{c}$ per 12.

Breeders-Golden tulips, bronze colors. Mixed, 50c per 12.

Cottage-Striped Tulips. Mixed colors, 50c per 12.

Double Tulips-Large long lasting tulips. Mixed, 50c per 12.

Single Tulips-The earliest tulip. Mixed color, 50c per 12.

\section{CROCUS}

Mixed Colors-Plant these little bulbs in your lawn. They are the first flower to bloom. $25 \mathrm{c}$ per $12 ; \$ 2.00$ per 100 .

\section{HYACINTHS}

Mixed Colors-White, Blue and Rose. $\$ 1.00$ per 12.

\section{LILIES}

Madonna Lily-Pure white with yellow stamens, very heavy bloomer, can be planted only in the fall. $35 \mathrm{c}$ each; 3 for $\$ 1.00$.

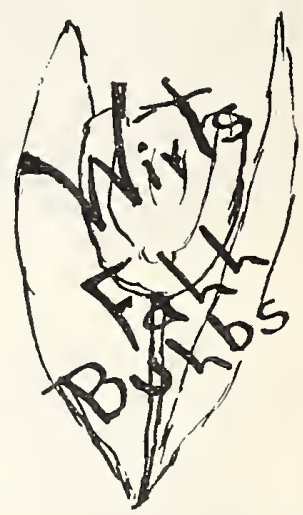

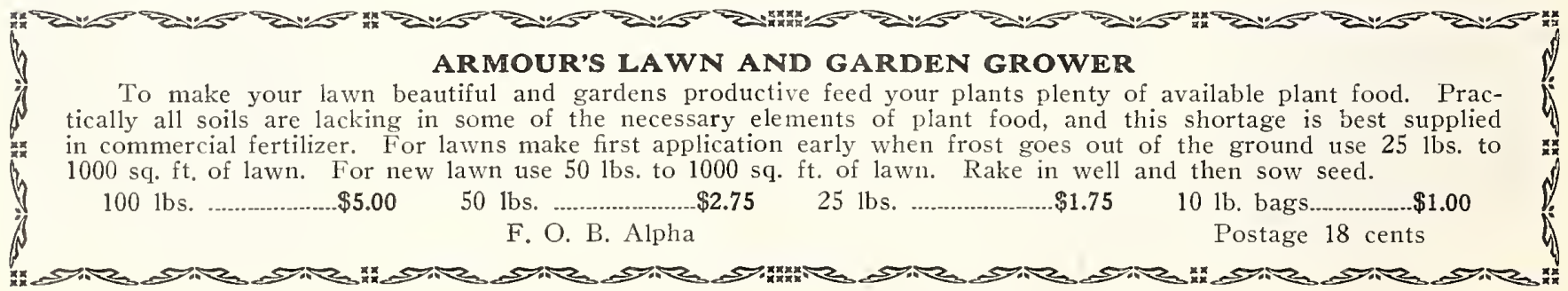




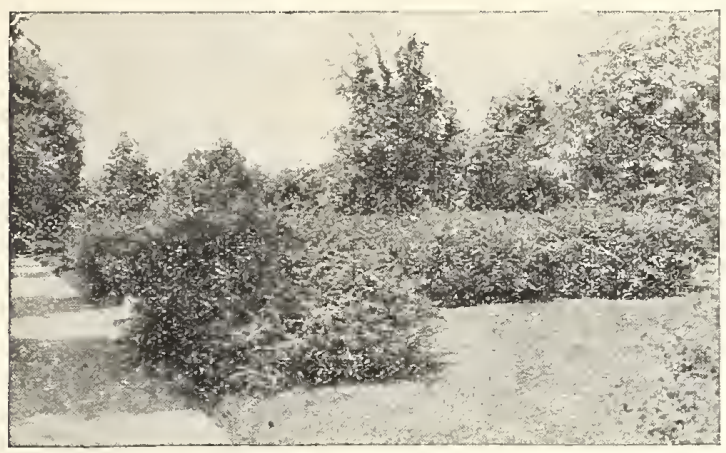

Barberry Hedge

Barberry-(Thunberg's or Japanese)-The finest of all the Barberries, grows in compact form, spiney stems, foliage fine and dense, changing to brilliant red in fall, the clusters of red berries hanging on all winter. Much used for hedge and borders. Considered by many to be the most valuable foreign slarub grown. This Barberry is recommended by the Government. It does not have the wheat rust.

State Size Wanted.

\begin{tabular}{|c|c|c|c|c|c|}
\hline $\begin{array}{c}\text { Size } \\
18-24 \text { in. } \\
12-18 \text { in. }\end{array}$ & $\begin{array}{c}\text { Each } \\
\$ .35 \\
.30\end{array}$ & $\begin{array}{c}3 \\
\text { plants } \\
\$ 1.00 \\
.80\end{array}$ & $\begin{array}{c}6 \\
\text { plants } \\
\$ 1.80 \\
1.50\end{array}$ & $\begin{array}{c}10 \\
\text { plants } \\
\$ 3.00 \\
2.50\end{array}$ & $\begin{array}{c}100 \\
\text { plants } \\
\$ 28.00 \\
17.50\end{array}$ \\
\hline Postage & .08 & .12 & .18 & .25 & Express \\
\hline $10-16$ in. size & .10 & \multicolumn{2}{|c|}{$\$ 1.00$ per 12 plants } & \multicolumn{2}{|c|}{$\$ 8.00$ per 100} \\
\hline Postage & .07 & \multicolumn{2}{|c|}{.10} & \multicolumn{2}{|c|}{.35} \\
\hline
\end{tabular}

\section{Wirt's Hedge Plants}

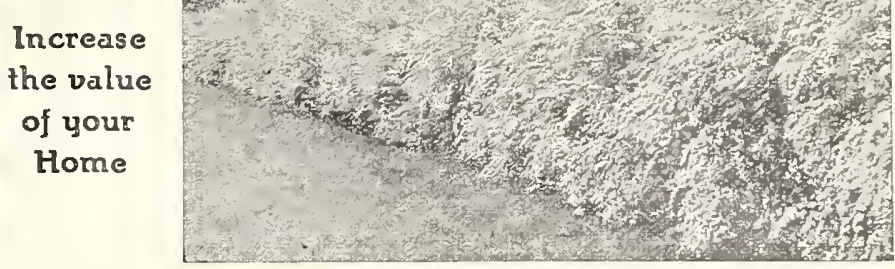

Bridal Wreath Iedge

Spirea Van Houttei-(Bridal Wreath)-Used for tall hedges or screens. Has abundance of small white flowers early in the summer.

State Size Wanted.

\begin{tabular}{|c|c|c|c|c|c|}
\hline $\begin{array}{l}\text { Size } \\
3-4 \text { feet } \\
2-3 \text { feet }\end{array}$ & $\begin{array}{c}\text { Each } \\
\$ .50 \\
.35\end{array}$ & $\begin{array}{c}3 \\
\text { plants } \\
\$ 1.40 \\
1.00\end{array}$ & $\begin{array}{c}6 \\
\text { plants } \\
\$ 2.70 \\
2.00\end{array}$ & $\begin{array}{c}10 \\
\text { plants } \\
\$ 4.00 \\
3.00\end{array}$ & $\begin{array}{c}100 \\
\text { plants } \\
\$ 30.00 \\
20.00\end{array}$ \\
\hline Postage & .10 & .15 & .70 & .28 & Express \\
\hline 12-18 in size & .10 & \multicolumn{2}{|c|}{$\$ 1.00$ per 12 plants } & \multicolumn{2}{|c|}{$\$ 8.00$ per 100} \\
\hline Postage & .07 & \multicolumn{2}{|c|}{.10} & \multicolumn{2}{|c|}{.35} \\
\hline
\end{tabular}

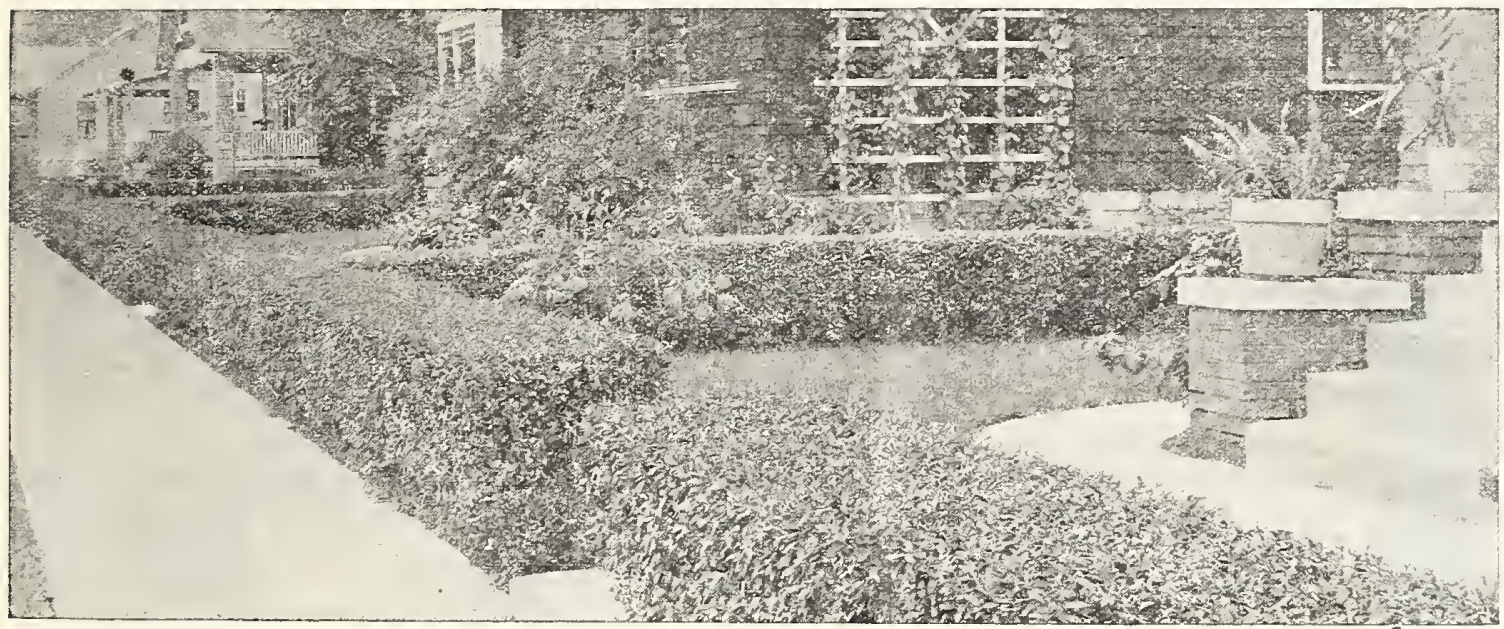

Amoor River Privet

makes a fine hardy hedge

$\$ 8.00$

per 100

Amoor River Privet-This is the hardy type of privet so much used for hedges. Has glossy green foliage which hangs on very late in the fall. This variety of Privet can be trimmed at any time into any shape. Plant Amoor Privet no matter where you live, it will increase the value of your place.

State Size Wanted.

\begin{tabular}{l|c|c|c|c|c|c|c}
\hline HARDY & Size & Each & 12 Plants & 25 Plants & 50 Plants & 100 Plants & 200 Plants \\
PRIVET & 12 to 16 in. & $10 \mathrm{c}$ & $\$ 1.00$ & $\$ 2.00$ & $\$ 4.00$ & $\$ 8.00$ & $\$ 15.00$ \\
PLANTS & 16 to $18 \mathrm{in}$. & $15 \mathrm{c}$ & $\$ 1.65$ & $\$ 3.20$ & $\$ 6.25$ & $\$ 12.50$ & $\$ 24.00$ \\
\cline { 2 - 7 } & Postage & $.07 \mathrm{c}$ & $\mathbf{1 2 c}$ & $18 \mathrm{c}$ & $27 \mathrm{c}$ & (By Express only) \\
\hline
\end{tabular}

\section{PLANTING}

Privet-Dig trench twelve inches deep or more and set the plants four to six inches deeper than they stood in the nursery row, or deep enough so the lower branches will be four to six inches under the ground. Such deep planting will make a compact hedge down to the ground line, but if the plants are set shallow there will always be undesirable open spaces at the base of the hedge. Some planters set Privet in a double row, eight to ten inches apart each way, which makes a very dense hedge. Cut Privet back to four inches after planted to promote thick new growth at lower part of plant. 


\section{WIRT'S EUERGREEnS qive color all year}

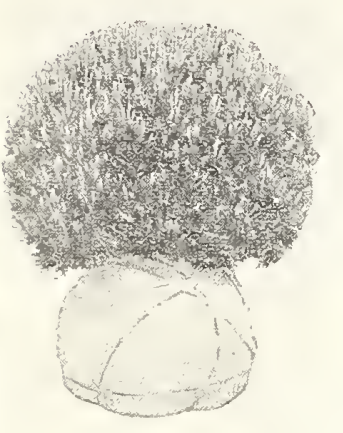

Mugho Pine

Evergreens are just the thing for foundation planting and general landscape work. They give color during the winter that cannot be obtained with any other shrubs or trees, and make a splendid contrast in the summer. We offer tall, medium and low growing evergreens. But all evergreens can be kept trimmed to any desired height. Trimming should be done in March.

Trees that are marked Balled should go by Express.

\section{NORWAY SPRUCE}

\section{Special Bargain}

This is a splendid evergreen for foundation and general planting, as it holds its bright green color all year, and when trimmed makes a very dense tree. They can be trimmed into many shapes.

$12-18$ in. trees balled $\$ 1.00$ each.

$18-20$ in. trees balled 1.50 each.

20-30 in. trees balled 2.00 each.

10-12 in. trees not ballcd $60 \mathrm{c}$ each.

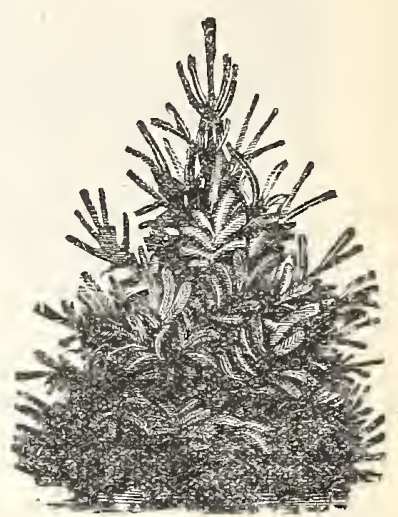

Norway Spruce

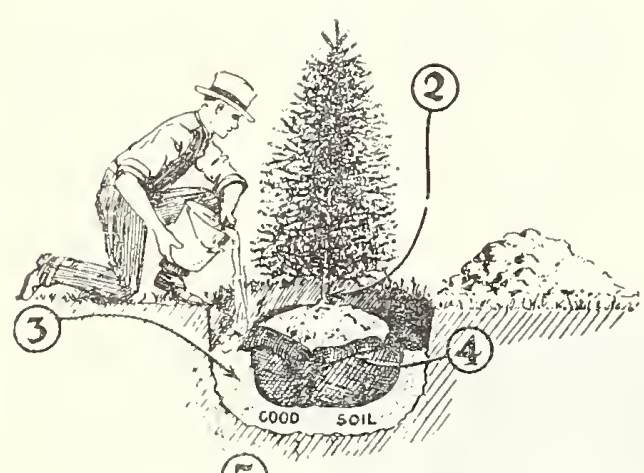

(5)

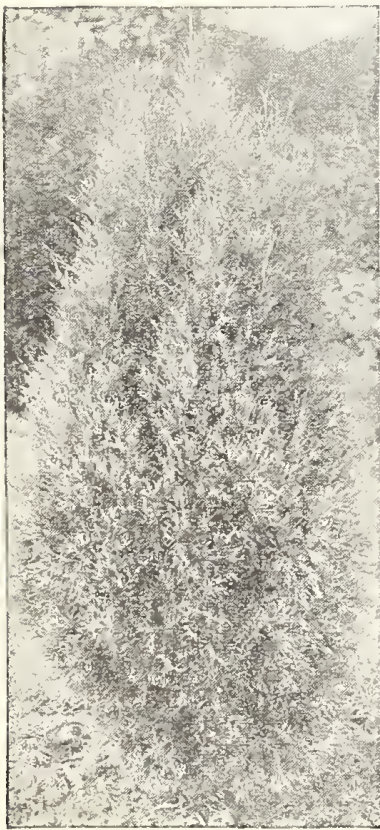

Cedar
PLANTING BALLED EVERGREENS

First-Dig a hole considerably larger than the balled tree.

Second-Set the tree into the hole a few inches deeper than it grew in the nursery.

Third-Fill the hole about half full of good soil (only).

Fourth-Cut the burlap in which the ball is wrapped and turn back.

Fifth-Put two or three buckets of water to each tree. When settled, fill the hole with soil. A little mulch of leaves is good.

Don't let your Evergreen set around. Plant as soon as received. They won't stand exposure to the sun.

\section{BLUE CEDAR}

This cedar is changeable; during the growing season it has a blueish cast, and is very pretty. Its habit is tall and slim. Splendid for corners, each side of the entrance and general planting.

5-6 ft. trees, balled, $\$ 8.00$ each. $3-4 \mathrm{ft}$. trees, balled, 3.00 each.

4-5 ft. trees, balled, 5.00 each. $12-16$ in. trees, not balled, $60 \mathrm{c}$ each.

\section{GLOBE ARBOR VITAE}

Here is a splendid low growing evergreen. Grows in a ball shape without trimming, and obtains a height of about 2 to $2 \frac{1}{2} 2^{i} \mathrm{ft}$. Color is light green. We offer compact specimens. $16-18$ in. trees, balled, $\$ 2.50$ each; 12-16 in. trees, balled, $\$ 2.00$ each.

\section{AMERICAN ARBOR VITAE}

This is a popular evergreen for hedges and foundation planting. Its habit is upright and can be trimmed into almost any shape. 2-3 ft. trees, balled, $\$ 2.00$ each; $18-24$ in. trees, balled, $\$ 1.00$ each.

\section{MUGHO PINE}

This is the most beautiful of all the dwarf pines. It grows in a ball shape without trimming. A fine tree where one of low growing habit is wanted. 10-12 in. trees, balled, $\$ 3.00$ each.

\section{IUNIPER IRISH}

This tree grows about 4 to 5 feet tall, and is of slender habit, bright green color, changing to a blueish cast at growing time. 18-24 in. trees, balled, $\$ 3.00$ each; $10-14$ in. trees, $60 \mathrm{c}$ each.

\section{JUNIPER WAUKEGAN}

This is a splendid low spreading evergreen, just the thing tor terraces and foundation planting. Color is bright green, the limbs are sinall and lacy. $15-18$ in trees, balied, $\$ 3.50$ each; $10-12$ in. trees, $75 \mathrm{c}$ each.

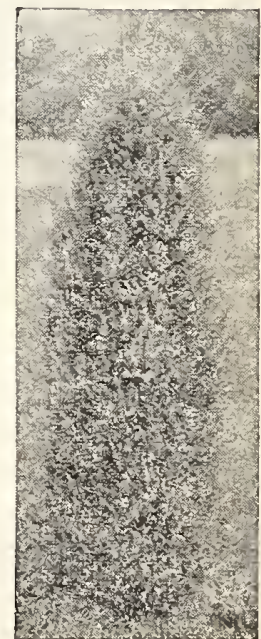

Irish Juniper 

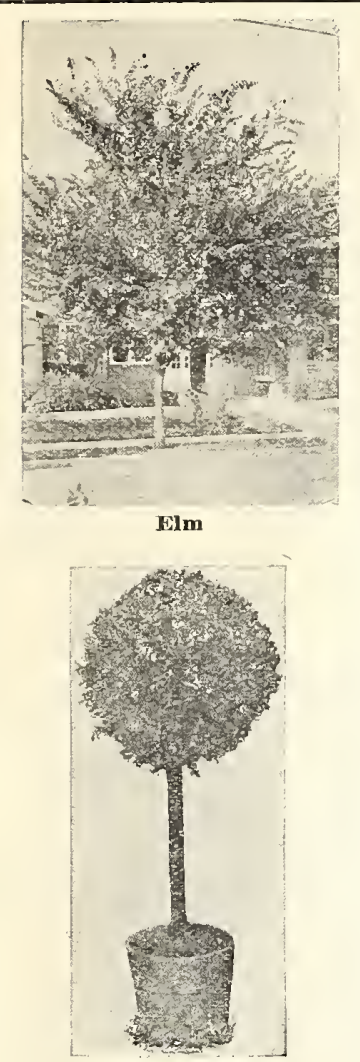

Tree Privet

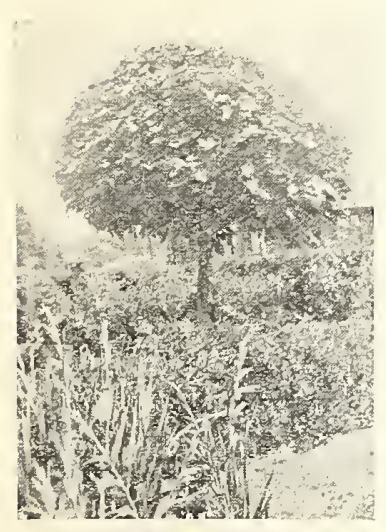

Catalpa Bungei

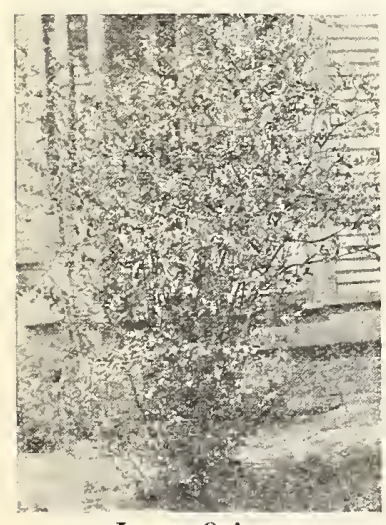

Japan Quince

See Shrubs on page $\%$.

\section{Plant}

\section{WIRT'S TREES for shade and beauty}

The spreading growth of shade trees will create much comfort for your home. Your property will increase in value by the pleasant surroundings.

Hard Maple-Spreading top, very dense shade. One of the very best trees for lawns or street. $8-10 \mathrm{ft}$. trees $\$ 2.00$ each; 6-8 ft. trees $\$ 1.50$ each.

Norway Maple-This tree is very much like the above, but is a little faster in growth. 6-8 ft. trees $\$ 2.00$ each.

Popular Norway-This is one of the fastest growing trees I have. It will grow anywhere. It makes a spreading head when trimmed. 6-8 ft. trees 50c each; 10-12 ft. trees $\$ 1.00$ each.

Popular Lombardi-This is the tree much used in landscape work as back ground, grows tall and slim. 10-12 ft. trees $\$ 1.25$ each; $8: 10 \mathrm{ft}$. trees $\$ 1.00$ each.

Elm Am. White-This is a splendid tree for street or lawn. It is fast growing and will give a lot of shade. 8-10 ft. trees $\$ 1.25$ each; 6-8 ft. trees $\$ 1.00$ each.

Moline Elm-A new tree, much like the white Elm, but grow more erect, hardy and long lived. 8-10 ft. trees $\$ 2.50$ each.

Flowering Crab (Bechtels)-A beautiful tree which blooms. The flowers are very fragrant, double, resembling small roses. Color, pink. Blooms in June. 2-3 ft, trees $\$ 1.00$ each.

Linden-A stately tree with large shining leaves, spreading in growth. 8-10 ft. trees $\$ 1.00$ each.

Red Bud-A small tree growing 12 to 15 feet tall. It is covered with reddish pink blooms early before the leaves appear. 5-6 ft. trees $\$ 1.00$ each.

Red Leaved Maple (Schwedlers)-This is the much admired Maple with the red leaves in the spring and again in the fall. Its growth is very much like the Hard Maple. Our trees are straight whips. 7-8 ft. trees $\$ 2.50$ each.

Birch Cut Leaved Weeping-A tall slender weeping tree, with white bark. Very popular as a lawn tree. The bark on my trees has not turned white, but will with age. 5-6 ft. trees $\$ 2.75$ each.

Mulberry Teas Weeping-Form a perfect weeping head, slender branched, drooping to the ground. A splendid ornamental tree. 4-6 ft. trees $\$ 3.00$ each.

Olive Russian-A small tree, bark dark green. Foliage rich silver color. Willow shaped leaves. 4-6 ft. trees $75 \mathrm{c}$ each.

Catalpa Bungeii-Umbrella Tree-Grafted on stems 4 to 6 feet high. It makes a perfect umbrella shape top without trimming. One of the best ornamental trees. 5-6 ft. 3 yr. trees $\$ 2.75 ; 5-6 \mathrm{ft}$. trees 2 yr. $\$ 2.00$ each; 4-5 ft. trees 2 yr. $\$ 1.50$ each.

Privet (Hardy tree Form)-These little trees are just the thing to put in tubs or plant on each side of your entrance. They come in heights 2,3 and 4 feet at $75 \mathrm{c}$ each or 2 for $\$ 1.40$.

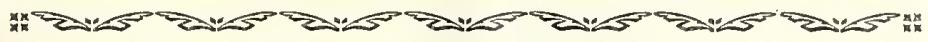

\section{SHEEP IMANURE}

Sheep manure is fine for grass, shrubs, trees, vines, vegetables, melons and small fruits, it can be used without fear of weed seed. A top dressing during any time in the summer will start new growth in your lawn or plants. Bone Meal mixed with sheep manure is the best combination of fertilizer one can use. Use 60 to $100 \mathrm{lbs}$. sheep manure to $1000 \mathrm{sq}$. ft. of surface.

5 lb. bags

10 lb. bags

$25 \mathrm{lb}$. bags

$50 \mathrm{lb}$. bags

$100 \mathrm{lb}$. bags
$\$ .30$ postage $10 \mathrm{c}$

.55 postage $18 \mathrm{c}$

1.25 F. O. B. Alpha

1.75 F. O. B. Alpha

3.00 F. O. B. Alpha

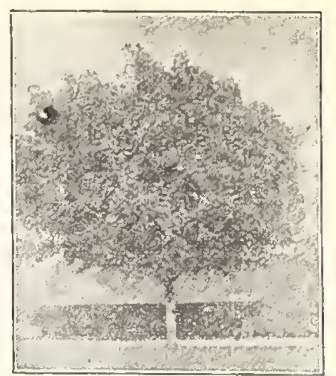

Hard Maple

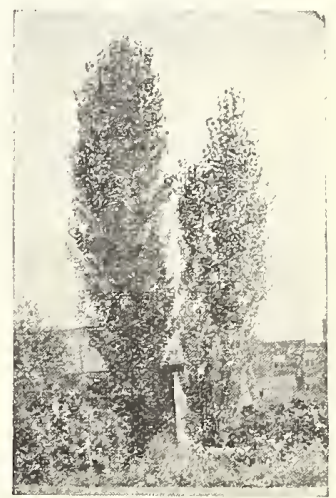

Lombardy

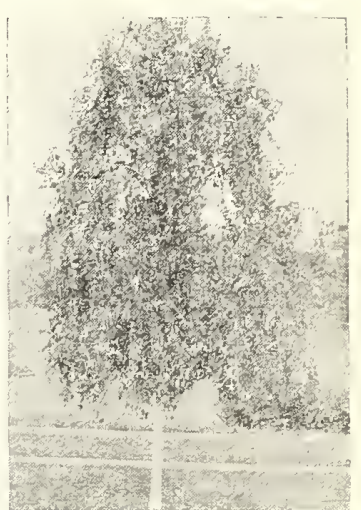

Birch

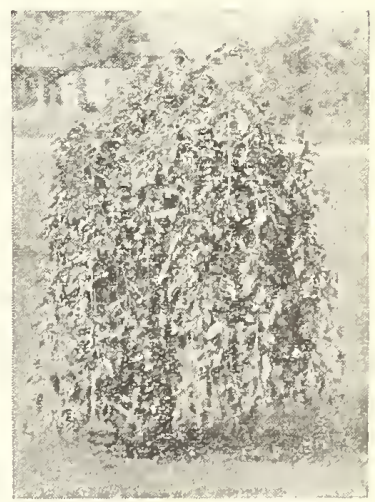

Weeping Mulberry 


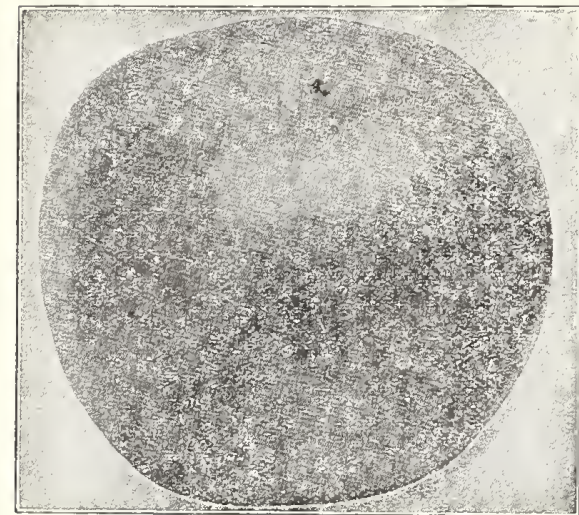

Stayman's Winesap

\section{$\underset{\tau T R E E S}{S T \text { WIRT'S APPLES 50 }} 0_{\text {each }}^{\text {ca }}$}

Are easy to grow. They thrive in almost every climate and soil. The Apple is the King of Fruits. Never were all conditions more favorable for the person who would plant an acreage of fruit for market purposes. A few acres of fruit with reasonable good care will bring a larger cash income per acre than anything one can grow.

State Size and Variety

\begin{tabular}{c|c|c|c|c}
\hline & Each & 5 trees & 10 trees & 25 trees \\
Express Size 4-6 ft., 2 yr. & $\$ .50$ & $\$ 2.35$ & $\$ 4.50$ & $\$ 11.00$ \\
Mail Size 3-4 ft., 1 yr. & .35 & 1.65 & 3.00 & 7.00 \\
Postage & .08 & .15 & .25 & Express \\
\hline
\end{tabular}

\section{SUMMER VARIETIES}

Early Harvest-Medium, to large, roundish, bright straw color, flesh white, good quality. July.

Astrachan Red-Large, roundish, nearly covered with crimson; juicy, sub-acid; tree strong, spreading grower. August.

Red June-Medium, oblong, hardy and productive; deep red color; flesh white, tendcr, rich and sub-acid. August.

Yellow Transparent-Medium, yellow, good quality, productive, early bearer. July.

\section{ATUMN VARIETIES}

Duchess of Oldenburg-Large size, roundish, streaked with red and yellow, flesh white, juicy, acid. September.

Famuese (Snow)-Medium, deep crimson, flesh snowy white, tender. Trce slow crooked grower. October and November.

Golden Sweet-Fruit large, pale yellow; flesh tender, sweet and rich; hardy and a good grower. August and September. Wealthy-Large, roundish, smooth, nearly covered with dark red; flesh white, fine, juicy, sub-acid; quality very good; good grower and productive. October.

\section{WINTER VARIETIES}

Balawin-Medium size, red, flesh yellow, sub-acid; tree a good grower, but a little tender here. December.

Delicious-Fruit large, nearly covered with brilliant dark red, flesh fine grained, crisp and melting, juicy, with a delightful aroma; of very highest quality. Dccember to February.

Tallman Sweet-Medium, pale yellow, firm, rich and very sweet, the most valuable preserving and baking apple; vigorous. October and December.

Gano-Good size, smooth and very attractive; deep red, resembles Ben Davis, but is an improvement on that variety, being handsomer and better colored. December to March. Golden Russet-Medium size; flesh greenish white, good quality; tree a good grower and hardy. January.
Grimes Golden-Medium golden yellow, with white dots, crisp, tender and juicy, excellent; tree vigorous, hardy and productive. November to January.

Jonathan-Medium, nearly covered with brilliant stripes of lively red; very showy, juicy, excellent; trees spreading and slender; bears early. November to February.

Mammoth Black Twig-Large, deep red, sub-acid; early and abundant bearer; keeps well; tree a strong grower; resembles Winesap, but is superior in many ways, and fully one-third larger. January to April.

Northwestern Greening-Large, smooth, greenish yellow; flesh fine graincd, firm; cxtreniely hardy and a strong, handsome grower. December to April.

Paradise Sweet-Medium size, greenish yellow, sweet, good quality. December.

Roman Stem-Medium size, yellow, of good quality, very productivc; tree a slow grower when young.

Golden Winesap-One of the newer varieties, yellow with slight red blush, juicy; flavor of the Jonathan and meatiness of the Winesap. Good size, good keeper. Dec. to March.

Winter Banana-Fruit large, color clear yellow, overspread with pink; red-blushed; flesh yellow, very rich and juicy; tree subject to blight. November to January.

Stayman's Winesap-Fruit large, striped, nearly covered with red; flesh greenish yellow, very juicy and aromatic; very good; a strong, spreading grower; a good, early bearer; the best of our late winter apples. January to May.

Winesap-Medium, roundish, decp red, frrm, crisp, juicy; excellent quality, moderate grower and good bearer; succeeds well throughout the West. December to May.

Seedless-A new apple from New Mexico, good keeper, this apple does not have seeds or core, the bloom is different from other apples. Decembcr to February. 4-6 ft. trees $\$ 1.00$ each.

\section{CRAB APPLES}

\section{Sturdy Trees 4 to 6 feet, 50c each.}

Transcendant-Large, golden yellow with blush; flesh firm, crisp, yellowish; fine grained, very juicy and acid. Popular for jelly and preserves. Trees grow rapidly and irregular; great bearer.

Hyslop-Large, round, yellow, with heavy shadings of deep crimson; blue bloom; flesh fine, firm, yellow. Its high color always commands a fancy market price. Bears abundantly and in clusters. Tree hardy and vigorous. September to October.

Whitney-Fruit very large, yellow striped with red, flesh yellow, very juicy and fine grained, flavor rich and almost sweet. August.

Sweet Crab-Large size, sweet, good bearer; whitish yellow. Fine for preserves and pickles. September. 


\section{PEACHES $45_{\text {cish }}^{\text {c. }}$}

A fresh ripe home grown Peach is mighty good. Peaches picked off your own trees, good and ripe sure hit the spot. Peaches will grow over a large season with very little care, they come into bearing very young, two years after planting they should bear.

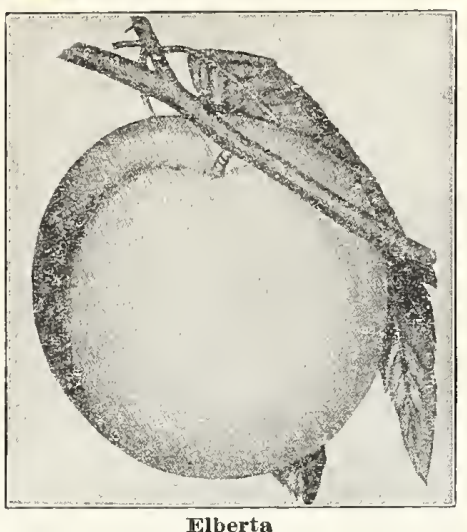

State Varieties and Sizes Wanted

\begin{tabular}{c|c|c|c|c}
\hline \multicolumn{1}{c|}{ Quality Trees } & Each & 5 trees & 10 trees & 25 trees \\
Express size 5-6 ft. & $\$ .45$ & $\$ 2.00$ & $\$ 3.75$ & $\$ 8.00$ \\
Mail size 3-4 ft. & .30 & 1.40 & 2.50 & 5.50 \\
\hline \multicolumn{1}{c|}{ Postage } & .07 & .15 & .25 & Express \\
\hline
\end{tabular}

Elberta-The great American market peach; produces big, profitable crops. Fruit large, bright, attractive, yellow with crimson shading; flesh firm and of good quality. Will ripen perfectly when picked green. One of the best for home or market ușe. Free stone. September.

Early Elberta-Smaller than Elberta, fruit yellow; of very good quality. Tree hardy and good bearer. Ripens about ten days earlier than Elberta.

Golden-Good size, golden yellow inside and out, of very good quality. Tree very hardy and a good bearer. Has proven to be a good variety here. September 10 to 15. J. H. Hale-Of large size, ripens earlier than Elberta, and is of good quality. Color, golden yellow inside and out, with a red cheek. Ripens in September.

Champion-Fruit large, delicious, sweet, juicy; skin creamy white, with red cheek; handsome, hardy and productive, and a good shipper; adhering slightly to the stone. White flesh-August 15 th.

Crosby-Freestone, medium size, bright yellow, streaked with carmine; annual bearer; hardy, September 15 th.

Crawford's Early-Freestone, large, yellow; flesh yellow, quality good; tree good grower, but the buds are tender. September.

Wilson-Fruit large, yellow with large blush. Flesh yellow and juicy. Ripens ten days earlier than Champion. Originated in Mercer County. Supply limited.

Greensboro-Medium size, almost solid red in color; flesh white and juicy. July.

Lemon Cling-Very large, light yellow; flesh firm, yellow and rich; the great canning peach of the South and West. August.

\section{CHERRIES}

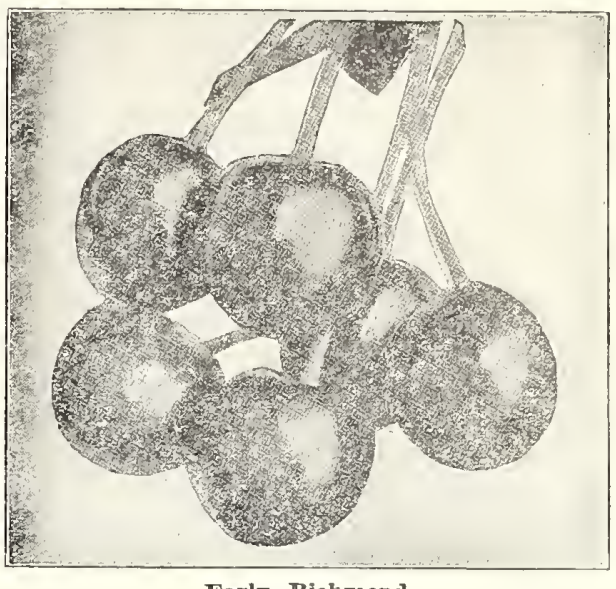

SOUR CHERRIES $80_{\text {ea }}^{c}$. ach

State Varieties Wanted

\begin{tabular}{c|c|c|c|c|c}
\hline Quality & Size & Each & 5 trees & 10 trees & 25 trees \\
Trees & $4-6 \mathrm{ft}$. & $80 \mathrm{c}$ & $\$ 3.95$ & $\$ 7.85$ & $\$ 17.00$ \\
\hline
\end{tabular}

Cherries are one of the fruits enjoyed by everyone. Sour cherries will grow in most any kind of soil and require very little care.

Early Richmond-This is the early popular cherry that is planted so much. Medium red, hardy, immensely productive, ripens the last of June.

Montmorency-The large, late, dark red cherry. This cherry has become very popular on account of size. It is very meaty-ripens about 10 days later than the Richmond.

May Duke-Large, red, juicy, rich-not as sour as many cherries. Tree strong, upright grower. June.

\section{SWEET CHERPIES $\$$ 1}

State Varieties Wanted.

\begin{tabular}{c|c|c|c}
\hline Size & Each & 5 trees & 10 trees \\
$4-6 \mathrm{ft}$. & $\$ 1.00$ & $\$ 4.75$ & $\$ 9.00$ \\
\hline
\end{tabular}

Sweet Cherries are not a sure bearer here, but they make a splendid tree for the lawn, as they are strong, upright in growth, and make a medium sized tree.

Bing-Very large, almost black, sweet, rich and delicious. July.

Spanish-Large size, yellow with blush cheek. June.

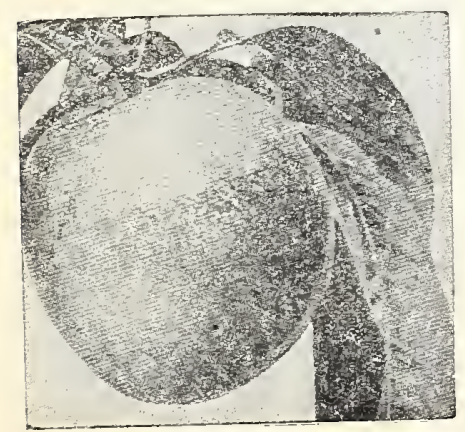

Superb

\section{APRICOTS $50^{\text {cich }}$}

The apricot is a very welcome fruit, ripening between the cherry and peach; it requires the same treatment as the plum; good bearer; fruit, light orange, flecked with red. Flesh tender, juicy. Sweet and good.

\begin{tabular}{c|c|c|c}
\hline & Each & 5 trees & 10 trees \\
Express size 3-4 ft. & $\$ .50$ & $\$ 2.35$ & $\$ 4.50$ \\
Mail size 3 ft. & .40 & 1.80 & 3.50 \\
\hline Postage & .08 & .15 & .25 \\
\hline
\end{tabular}

Moorpark-Yellow, with red cheek, juicy, sweet and rich, freestone, very productive. Superb-A hardy seedling from Kansas. The best flavored, most productive hardy apricot yet produced. Medium size, light salmon color. 


\section{Quality WIRT'S PEARS $80 \mathrm{c}$. each}

State Varieties Wanted

\begin{tabular}{c|c|c|c|c|c}
\hline Quality & Size & Each & 5 trees & 10 trees & 25 trees \\
Trees & $5-6 \mathrm{ft}$. & $80 \mathrm{c}$ & $\$ 3.90$ & $\$ 7.60$ & $\$ 18.00$ \\
\hline
\end{tabular}

Bartlett-Large size, rich, yellow color, with a blush; very juicy and highly flavored; good to eat from the tree. This is the variety that is sold at fruit stands.

Kieffer-The best late pear-does not ripen on the tree. Pick them before frost and lay them away. Heavy and sure bearer; good for canning.

Duchess--The largest of the eating pears, flesh white, very juicy, and excellent flavor. October.

Lincoln-Large, golden yellow, heavy bearer; very good eating and canning.

Seckle-The small, sweet pear. Surely fine to eat from the tree. The tree is a slow grower, but very hardy. Sept.

\section{DWARF PEARS}

4 to 5 feet, $80 \mathrm{c}$ each

Dwarf Pears-In Bartlett, Duchess and Seckle. The fruit is the same as the Standard Pear; the tree grows smaller, and bears much earlier.

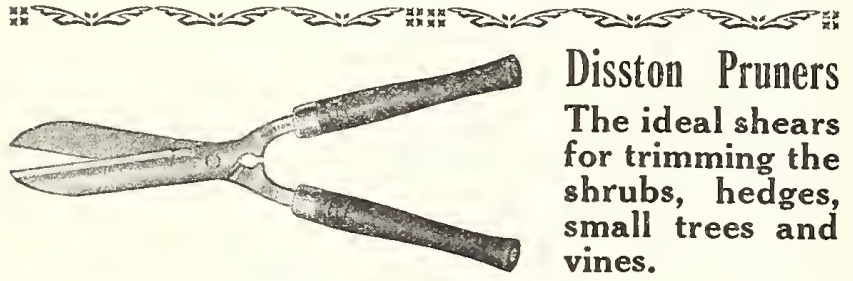

Disston's XX. Best grade $\$ 3.25$ Postpaid. Utility Grade $\$ 2.20$ Postpaid.

\section{PLUMS 65c. each}

State Varieties Wanted.

\begin{tabular}{c|c|c|c|c}
\hline Quality Trees & Each & 5 trees & 10 trees & 25 trees \\
Express size 4-5 ft. & $\$ .65$ & $\$ 3.15$ & $\$ 6.20$ & $\$ 14.00$ \\
Mail Size 3-4 ft. & .45 & 2.00 & 4.75 & \\
\cline { 1 - 3 } & .07 & .18 & .25 & Express \\
\hline
\end{tabular}

Blue Damson-Enormously productive. Fruit small size, about an inch long; skin purple, covered with thick blue bloom; flesh melting and juicy, rather tart, separates partially from the stone. September.

Green Gage-Medium sized yellow free-stone, of extra good quality; tree a slow, dwarfish grower. August.

Wild Goose-Hardy, native, deep red with purplish bloom; flesh yellow, juicy and sweet; rapid grower; early and abundant bearer. July and August.

Red June-A vigorous, hardy, upright, spreading tree; as productive as Abundance. Fruit medium to large, deep vermillion red, with handsome bloom; very showy, flesh light lemon color, slightly sub-acid, of good and pleasant quality; pit small. Early.

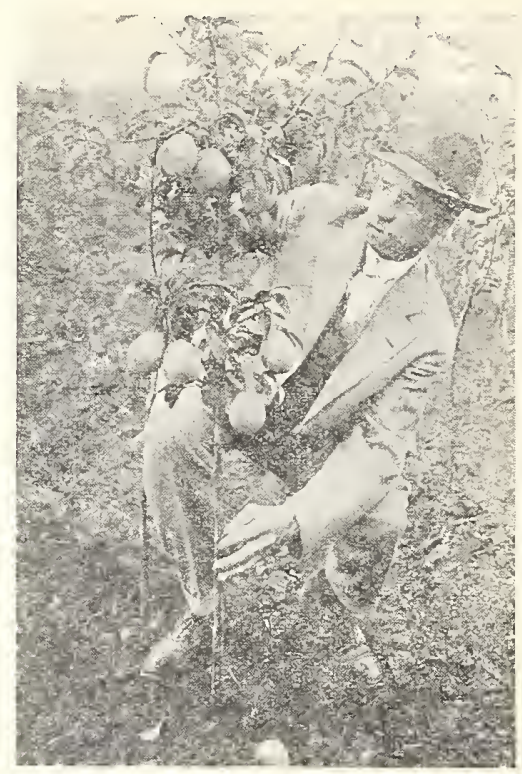

Douglas Pears have everything

Flavor, Beauty, Size, Color Quality, Shape, Refinement

Ships Splendidly and Keeps Well

"Fruit large handsome and of superior quality."

-Luther Burbank

\begin{tabular}{c|c|c|c}
\hline & Each & 2 trees & 5 trees \\
Express size 4-5 ft. & $\$ 1.50$ & $\$ 2.80$ & $\$ 6.75$ \\
Mail size 3-4 ft. & 1.00 & 1.90 & 4.50 \\
\hline Postage & .08 & .12 & .25 \\
\hline
\end{tabular}

FRUIT AT 10 MONTHS

Here is a photograph of a 10 month old "DOUGLAS" Pear tree bearing fruit. No other pear tree or apple tree on earth bears at as young an age as the great "DOUGLAS." 10,11 and 12 month trees frequently bear in the nursery row. 2 year olds often need branch support so heavy their yield of fruit.

Here is a blight-free pear-in which is combined the best qualities and habits of all leading varieties-with the drawbacks of none. It bears even more profusely than the Kieffer. It begins to bear at an earlier age than any other pear on earth. It ranks with the best in shape, size and coloring. In flavor it excels others-rich, melting, sweet, juicy, tender-altogether delicious.

\section{Hansen Hybrid Plums}

\begin{tabular}{c|c|c|c} 
& Each & 3 trees & 6 trees \\
Express size 4-6 ft. & $\$ .60$ & $\$ 1.50$ & $\$ 2.90$ \\
Mail size 3-4 ft. & .40 & 1.00 & 1.90 \\
\hline Postage & .07 & .15 & .25 \\
\hline
\end{tabular}

New plums introduced by Professor Hansen, of the South Dakota Experiment Station, at Brookings, who has originated many new fruits, which are of great value and importance to all sections of the country. One important feature of these Hybrid Plums, is their good quality, extreme hardiness, prolificness and early bearing.

Hanska-Cross between native Plum and Apricot Plum of China, fruit splendid for eating out of the hand, and when cooked, retains the apricot flavor, fruit about one and onehalf inches in diameter, red in color, flesh firm, yellow, good quality. Begins to bear the second year. Hardy.

Sapa-Fruit dark purple, thin skin, red purple flesh. Very fine for eating and cooking, fine flavor and very prolific bearer. Fruit borne in clusters around the stem; trees three years old have borne as high as one and one-half bushels. Hardy.

Opata-Dark purplish red. Flesh green, flavor spicy, rich and sweet. Tree vigorous and hardy. A very productive and early bearer. Ripens in July. 


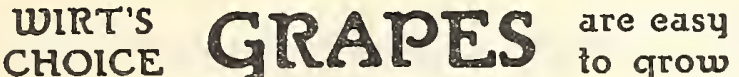

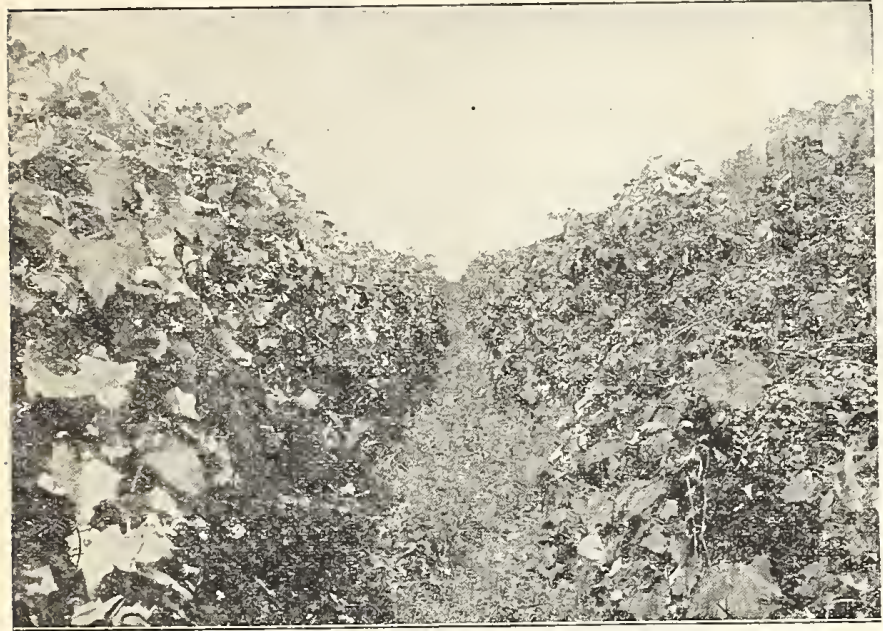

Grapes in Nursery

Concord-Black, the most popular grape in America; bunches and berries are large, hardy, healthy and productive. 2 yr. plants $15 \mathrm{c}$ each; $\$ 1.20$ per $10 ; \$ 10.00$ per 100 . 1 yr. plants $10 \mathrm{c}$ each; 90c per $10 ; \$ 7.00$ per 100 .

Moore's Early-Black, bunches medium size and very compact; berries large and of excellent quality; ripens ten days before Concord which makes it very desirable for market; very hardy, well suited for the North; one of the best. 2 yr. plants $25 \mathrm{c}$ each; $\$ 2.00$ per 10 . 1 yr. plants $20 \mathrm{c}$ each; $\$ 1.50$ per 10 .
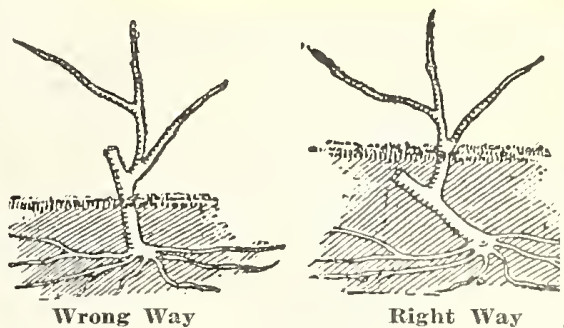

PLANTING

Grapes should be planted about 8 feet apart. Make the soil mellow and plant the vines 10 to 12 inches deep in holes large enough to admit roots without curling them, pressing soil about roots Cut vines back to within three or four buds of the roots.

\section{GRAPE SPRAY}

Grapes should be sprayed with Bordeaux Mixture. This will control black rot, mildew and all leaf eating insects. 1 lb. Bordeaux Mixture to 5 gal. water and add about 2 tablespoons of dry Arsenate Lead. We can furnish Bordeatux at 50c per lb. Postpaid.

Caution-Do not use lime-sulphur in spraying Grapes.

Postage, 1 to 3 plants, $8 \mathrm{c}$; 4 to $6,12 \mathrm{c} ; 6$ to $10,15 \mathrm{c}$.

Campbell's Early-A strong grower, an abundant bearer; bunches and berries very large, glossy black; ripens with the Moore's Early, but will hang on the vines until frost. 2 yr. plants $30 \mathrm{c}$ each; $\$ 2.50$ per 10 . $1 \mathrm{yr}$. plants $20 \mathrm{c}$ each; $\$ 1.75$ per 10 .

Agawam-Red or maroon color; berries large, of rich, peculiar aromatic flavor; ripens a week later than Concord; vine a strong rank grower. 2 yr. plants $25 \mathrm{c}$ each; $\$ 2.00$ per 10 . 1 yr. plants 20c each; $\$ 1.50$ per 10 .

Catawba-Bunches of good size, fruit when ripe is copper color with a sweet rich musky flavor; a fine wine grape. 2 yr. plants $25 \mathrm{c}$ each; $\$ 2.00$ per 10 . 1 yr. plants $15 \mathrm{c}$ each; $\$ 1.20$ per 10.

Moore's Diamond-White, bunches and berries large; flesh tender, juicy; hardy, productive, early; fine quality. 2 yr. plants $25 \mathrm{c}$ each; $\$ 2.00$ per $10.1 \mathrm{yr}$. plants $20 \mathrm{c}$ each; $\$ 1.50$ per 10.

Caco-A novelty in Grapes, a cross between Catawba and Concord. Wonderful grower. Can be grown in the back yard without attention. Has large wine red berry in bunches of good size. Ripens 10 days before Concord. Be sure to add a few vines. $1 \mathrm{yr}$. plants $45 \mathrm{c}$ each; $\$ 4.00$ per 10 .

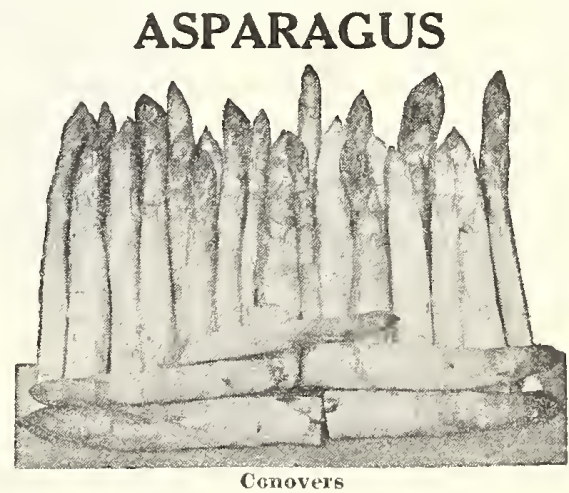

\begin{tabular}{c|c|c|c|c|r}
\hline Variety & Size & 12 & 25 & 50 & 100 \\
Conovers & 2 year & $\$ .30$ & $\$ .55$ & $\$ 1.00$ & $\$ 2.00$ \\
Washington & 2 year & .35 & .65 & 1.20 & 2.10 \\
\hline Parcel Post & & .10 & .18 & .25 & .35 \\
\hline
\end{tabular}

Conovers-An old standard variety of large size, tender, and of excellent quality.

Washington-A new rust resistant pedigreed asparagus. A fine fancy variety for home or market use. Tender, large and high quality. 

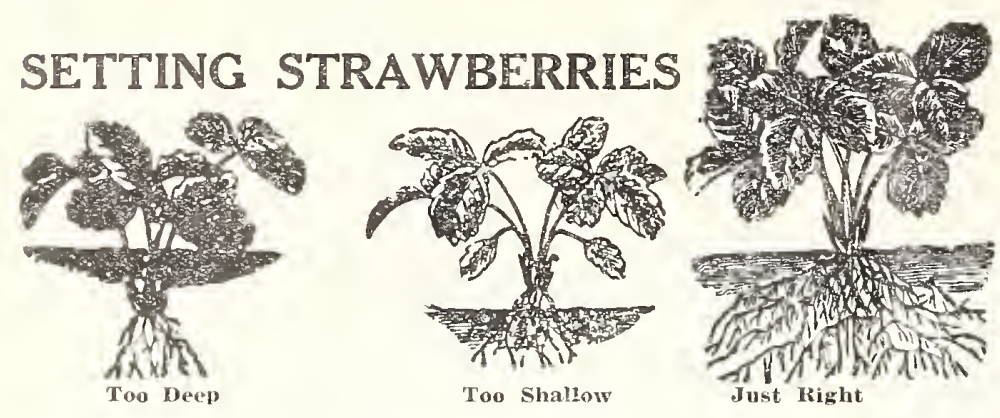

\section{Wirt's Quality Home Grown Plants \\ Strawberries $\$ 1.00$ per 100}

\begin{tabular}{|c|c|c|c|c|c|c|c|c|}
\hline Varieties & 12 plants & 25 plants & 50 plants & 100 plants & 200 plants & 300 plants & 500 plants & 1,000 plants \\
\hline Senator Dunlap & $\$ .25$ & $\$ .35$ & $\$ .60$ & $\$ 1.00$ & $\$ 1.90$ & $\$ 2.85$ & $\$ 4.50$ & $\$ 6.00$ \\
\hline Dr. Burrill & .25 & .35 & .60 & 1.00 & 1.90 & 2.85 & 4.50 & 6.00 \\
\hline Gibson & .25 & .40 & .70 & 1.25 & 2.25 & 3.30 & 5.00 & 8.00 \\
\hline Aroma & .25 & .40 & .70 & 1.25 & 2.35 & 3.30 & 5.00 & 8.00 \\
\hline Mastodon & .90 & 1.50 & 2.00 & 3.00 & 5.50 & & & \\
\hline Postage & .07 & .09 & .10 & .12 & .15 & .20 & \multicolumn{2}{|c|}{ By Express } \\
\hline
\end{tabular}

\section{EARLY VARIETIES}

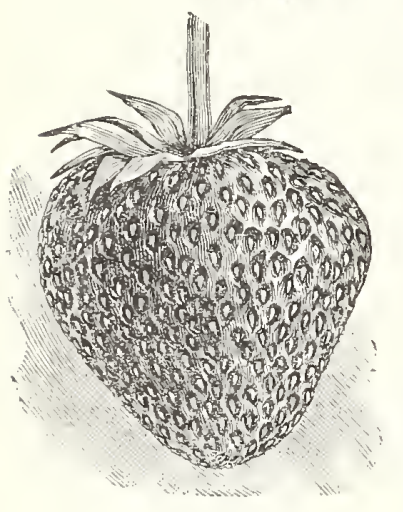

Dunlap
Senator Dunlap-This is the best known variety in the $\mathrm{U}$. $\mathrm{S}$. It bears well in all localities, producing big crops and big berries; very lardy; rich dark red color. Good plant producer, making wide heavy rows.

Dr. Burrill-The Million Dollar Strawberry. A valuable new variety, the berries are dark red and of excellent flavor; very solid, thus being a good shipper. Hardy and heavy bearer.

\section{MID-SEASON VARIETIES}

Gibson-Large berries of evenly colored, glossy dark red; firm with rich flavor. Stands shipping or hauling well-reaching market in the best of condition. Even in size to the end of the season. Gibson plants have the reputation among growers of producing more berries in one picking than most of varieties will through out the season.

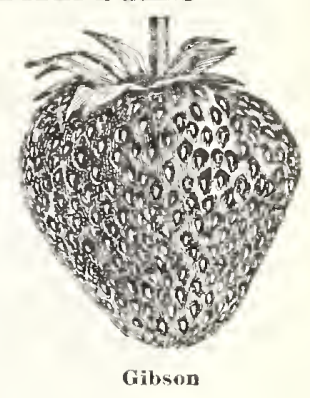

\section{CURRANTS}

State Variety Wanted

\begin{tabular}{c|c|c|c|c}
\hline Variety & & Each & 6 plants & 12 plants \\
Perfection & Size & $\$ .25$ & $\$ 1.40$ & $\$ 2.75$ \\
Red Cross & 2 year & .20 & 1.10 & 2.00 \\
White & 2 year & .20 & 1.10 & 2.00 \\
Parcel Post & 2 year & .10 & .20 & .30 \\
\hline
\end{tabular}

Perfection-A wonderful currant, very large size, bright red; less acid than any other large currant.

Red Cross-A strong growing variety with long clusters. Berries medium size, bright red, mild and good.

White-One of the best white currants. Bunches long and large; good quality.

\section{LATE VARIETIES}

Aroma-A standard late variety-starts ripening when the other varieties are gone. The berries are medium to large, dark red and fine; will stand lots of rough handling.

\section{EVERBEARING VARIETIES}

Mastodon-The elephant of strawberries, and bears lots of big berries from summer until frost. Plants set in April had ripe berries July 11 th, and the first week in August 160 quarts every five days per acre, and in Sept., 576 quarts per acre every five days. The late berries sure bring the price. This is the newest and best everbearer on the market today. Try a

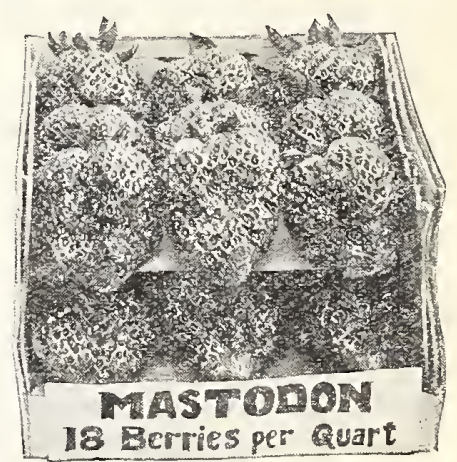
few of the plants.

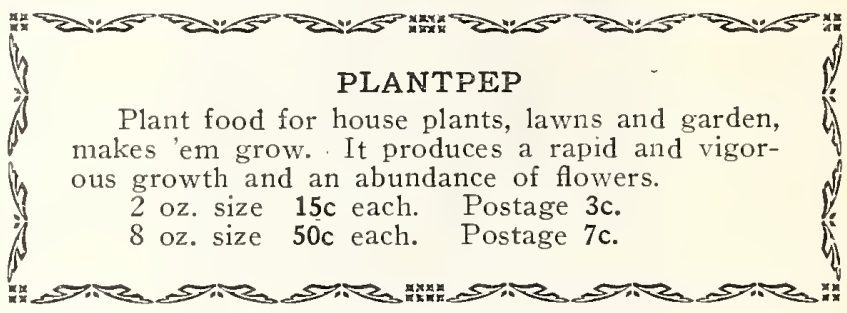

\section{GOOSEBERRIES}

\section{State Variety Wanted}

\begin{tabular}{c|c|c|c|c|c}
\hline & & 3 & 6 & 12 \\
Variety & Size & Each & Plants & Plants & Plants \\
Champion & 2 year & $\$ .30$ & $\$ .80$ & $\$ 1.50$ & $\$ 2.90$ \\
Pearl & 2 year & .30 & .80 & 1.50 & 2.90 \\
Parcel Post & & .10 & .15 & .20 & .30 \\
\hline
\end{tabular}

Champion-Fruit medium size, round. Bush very hardy and very productive; free from mildew. We think this is the best for general planting.

Pearl-One of the large varieties. Very hardy, but moderately productive. 


\section{WIRT'S HOME GROWN PLANTS \\ RASPBERRIES $50_{\text {per } 12}^{c_{1}}$}

Raspberries are easy to grow with a little care. Every garden should have a few varieties. There is a great demand for the fruit, never enough to supply the demand.

Raspberries are tied 25 to the bunch, the top canes are left 6 to 10 inches long, for the sole purpose of tying them in bunches, and after planting this cane generally dies, and the plant starts from the crown or root. In planting spread the roots out good, cover the crown from 2 to $2 \frac{1}{2}$ inches with soil. Do not put manure next to the roots. Cultivate good the first year, then mulch heavy along the row.

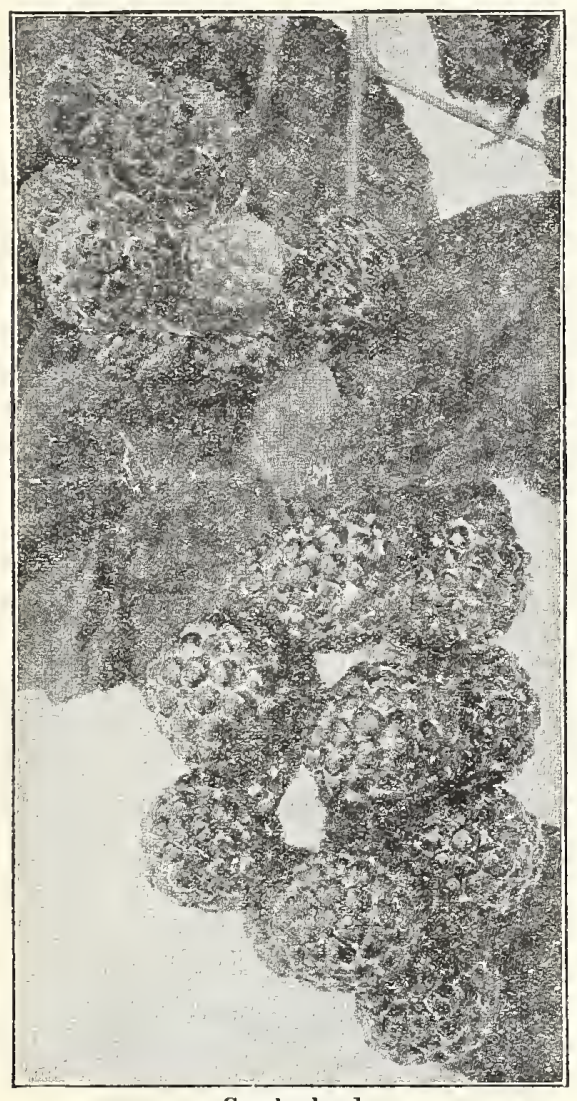

Cumberland

State Varieties Wanted

Variety

Cumberland

St. Riggs Red

Columbia Purple

Early King Red

Parcel Post

\begin{tabular}{|c|c|c|c|c}
12 & 25 & 50 & 100 & 1000 \\
plants & plants & plants & plants & plants \\
$\$ .50$ & $\$ .95$ & $\$ 1.80$ & $\$ 3.50$ & $\$ 28.00$ \\
.85 & 1.40 & 2.50 & 4.00 & 35.00 \\
1.00 & 1.80 & 3.25 & 6.00 & \\
.75 & 1.40 & 2.50 & 4.00 & 30.00 \\
\hline .08 & .12 & .18 & .25 & Express \\
\hline
\end{tabular}

Quality Plants-Fresh Dug.
Cumberland-One of the largest black raspberries known; its immense size, firmness and great productiveness entitles it to first consideration. Unusually strong grower, throwing up stout, stocky canes; perfectly hardy. The most valuable profitable raspberry grown for home or market use. Fruits for long season.

St. Regis (Everbearer)-Very early, fruit large and extra quality, good stocky grower and hardy. It is very much like the Louden except it makes a fall crop of the new canes. Red variety. (Sprouts).

Purple Columbia-Deep purplish red, highly flavored, extra strong canes, wonderfully productive; berries very large. There is nothing finer grown in the line of fruit than this variety for table use, canning, etc. This variety does not sprout.

Early King-This is one of the leading varieties of the Reds. The fruit is large and solid, does not mush up or break apart. The plants are almost disease proof. Try a few of this variety, you will like them.

\section{DEWBERRIES}

\begin{tabular}{|c|c|c|c|c|}
\hline $\begin{array}{c}\text { Size } \\
2 \text { yr. No. } 1\end{array}$ & $\begin{array}{l}12 \\
\text { plants } \\
\$ .75\end{array}$ & \begin{tabular}{l}
\multicolumn{1}{c}{25} \\
plants \\
$\$ 1.40$
\end{tabular} & $\begin{array}{c}50 \\
\text { plants } \\
\$ 2.20\end{array}$ & $\begin{array}{c}100 \\
\text { plants } \\
\$ 4.00\end{array}$ \\
\hline Postage & .08 & .12 & .18 & .25 \\
\hline
\end{tabular}

Lucretia-A trailing blackberry, much larger and juicier than blackberries. Dewberries are fine for planting on hillsides or banks that wash-they will hold the soil.

\section{BLACKBERRIES}

\begin{tabular}{|c|c|c|c|c|}
\hline $\begin{array}{c}\text { Size } \\
2 \text { yr. No. } 1\end{array}$ & $\begin{array}{l}12 \\
\text { plants } \\
\$ .75\end{array}$ & $\begin{array}{l}25 \\
\text { plants } \\
\$ 1.40\end{array}$ & $\begin{array}{c}50 \\
\text { plants } \\
\$ 2.20\end{array}$ & $\begin{array}{l}100 \\
\text { plants } \\
\$ 4.00\end{array}$ \\
\hline Postage & .08 & .12 & .18 & .25 \\
\hline
\end{tabular}

Eldorado-Vcry productive and hardy; extra fine quality; sweet flavor, without core; fruit very large, jet black. We think this is the best of blackberries.

\section{MULBERRIES}

Mulberries, Russian-Tree ornamental, as well as productive; bears very large, handsome black fruit of rich flavor. 4 to $5 \mathrm{ft}$. trees, $65 \mathrm{c}$ each.

\section{QUINCE}

Quince (Orange)-The quince is in very high favor because of its many uses, such as canning, preserving, and flavoring other fruits. This variety is golden yellow, flesh firm, of good flavor; bears abundantly. 4 to $5 \mathrm{ft}$. trees, $\$ 1.00$ each.

\section{CEESTNUTS}

American Sweet-The nuts of this tree form quite an item in our commerce. They are sweet and delicately flavored. This chestnut is also a grand timber and ornamental shade tree. 4 to $6 \mathrm{ft}$. trees, $\$ 1.00$ each.

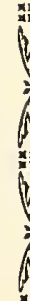

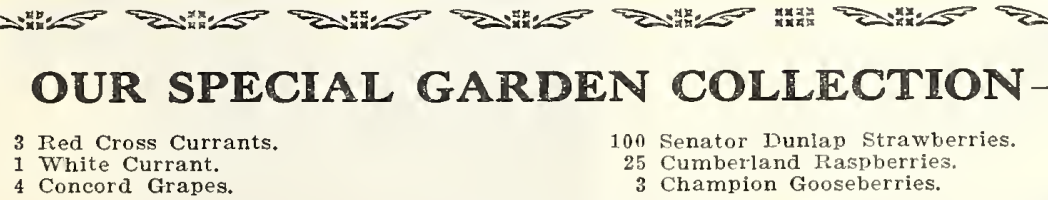

\section{OUR SPECIAL GARDEN COLLECTION}

3 Red Cross Currants.

1 White Currant.

4 Concord Grapes.

100 Senator Dunlap Strawberries.

25 Cumberland Raspberries.

3 Champion Gooseberries. EVERYTHING FOR THE SMALL
HOME GARDEN

$\begin{aligned} 2 & \text { Moore's Early Grapes. } \\ 6 & \text { Pieplant. } \\ 25 & \text { Washington Asparagus. }\end{aligned}$ 


\section{WIRT'S HARDY PERENNIALS}

ALI PERENNIALS ARE SENT POSTPAID

Hardy perennials or old-fashioned hardy garden flowers are among the most useful and beautiful of ornamental plants. They are usually a little hard to transplant but when once started, they are very hardy and will live from year to year, each season producing a wonderful mass of beautiful blooms. You will find them especially fine for borders, for foundation plantings, along paths and to cover unsightly places in one's yard. If you plant hardy perennials, your worries should cease for they come up every spring from the roots without further bother of planting.

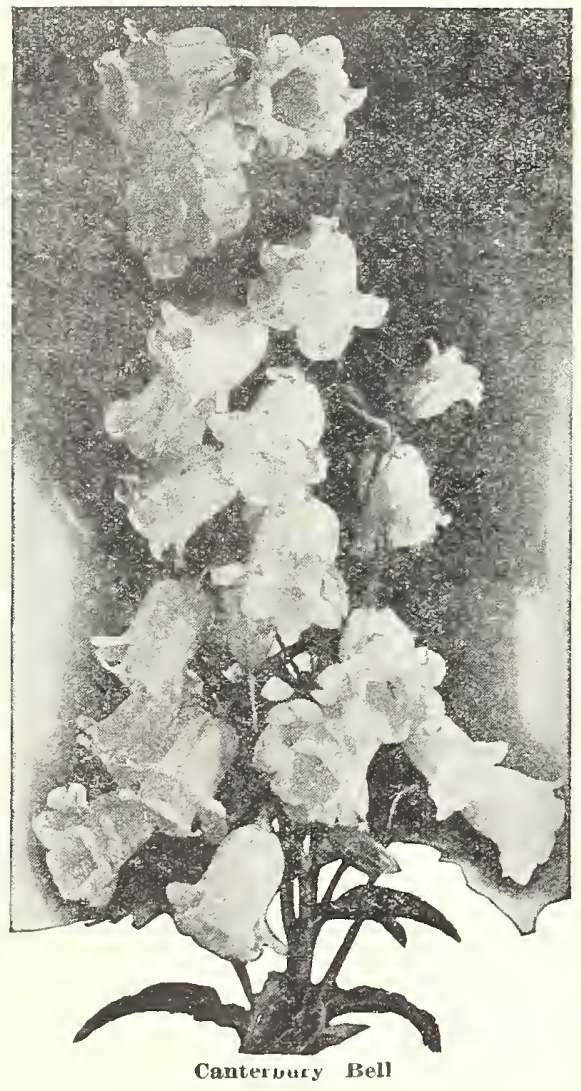

CAMPANULA

Canterbury Bells

Grows 2 feet tall, blooms in June and July. Separate colors, white, blue and rose. $25 \mathrm{c}$ each; 3 for $70 \mathrm{c}$.

\section{ASTERS}

Hardy Asters

Excellent fall blooming flower. Artis-Sky blue, grows $3 \mathrm{ft}$. 30c each. Climax-White, grows $31 / 2$ ft. $30 \mathrm{c}$ each.

St. Egyn-Dark blue, foliage good all summer. Grows 4 ft. $30 \mathrm{c}$ each; 3 for $75 \mathrm{c}$.

\section{BLEEDING HEART}

Fern Leaved-Everblooming. Has fern like foliage. Very fine border plant. 40c each; 3 for $\$ 1.00$.

\section{COREOPSIS}

Tickseed

Lanceolat Grandiflora-One of the beautiful yellow daisies. Fine for cutting. Blooms all summer. 20c each; 3 for 50 c.

\section{BUTTERFLY BUSH}

\author{
Summer Lilac
}

Makes a bush 3 to 4 feet tall, but freezes to the ground during winter. The bush is just covered with long racemes of Lilac-like flowers. Blooms in July and Aug. Very attractive. $30 \mathrm{c}$ each; 3 for $80 \mathrm{c}$.

\section{HARDY CHRYSANTHEMUMS}

These are the last flowers to bloom in the fall, and come in a host of colors. 20c each; 3 for 50c.

Autumn Glow-Rosy crimson.

Eva-Rosy pink.

Indian-Brownish red.

Little Bob-Bronze button.

Snowclad-Pure white.

Yellow Queen-Golden Yellow.

\section{DIANTHUS BARBARTUS}

\section{Sweet William}

An old fashioned favorite, blooms from May into July. No garden is complete without Sweet Williams.

Holborn Glory-A fine strain of mixed colors. 20c each; 3 for $50 \mathrm{c}$.

Carnation Hardy-Flowers very fragrant, produced on long stems. Scarlet. 25c each; 3 for $70 \mathrm{c}$.

\section{AQUILEGIA}

Rocky Mountain-Bright blue and white, long spurred. $25 \mathrm{c}$ each; 3 for $70 \mathrm{c}$.

Canadensis-Native, bright red and yellow. 20c each; 3 for $50 \mathrm{c}$.

Chrysantha-Bright yellow, long spurred flowers. 25c each; 3 for $70 \mathrm{c}$.

Wirt's Long Spurred Hybrids-All colors, pink, lavender, blue, white and red. $25 \mathrm{c}$ each; 3 for $70 \mathrm{c}$.

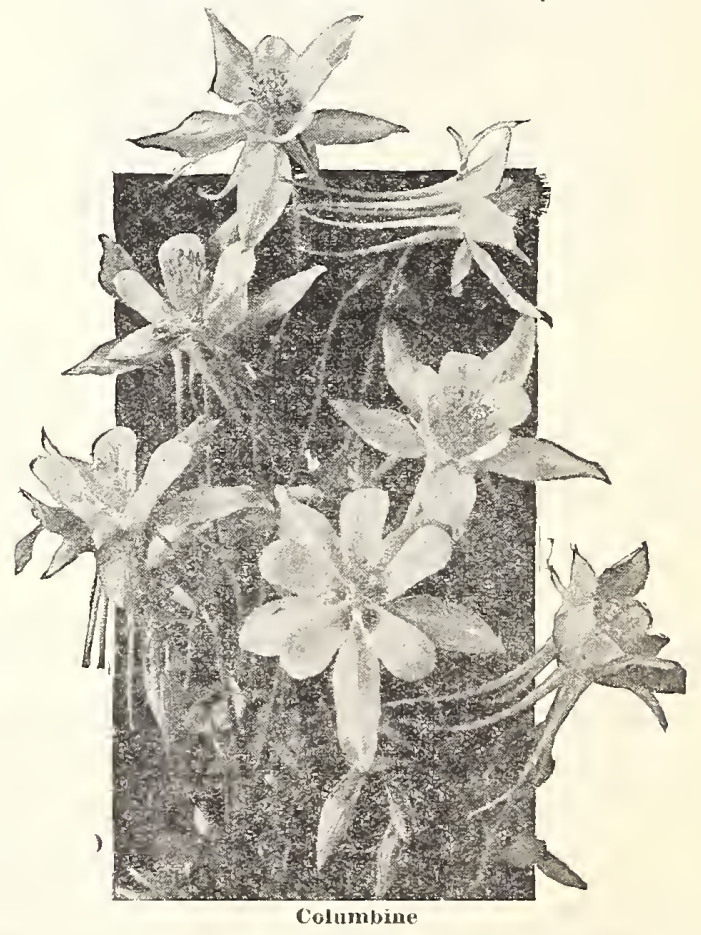




\section{WIRT'S HARDU PERENNIALS}

ALL PERENNIALS ARE SENT POSTPAID

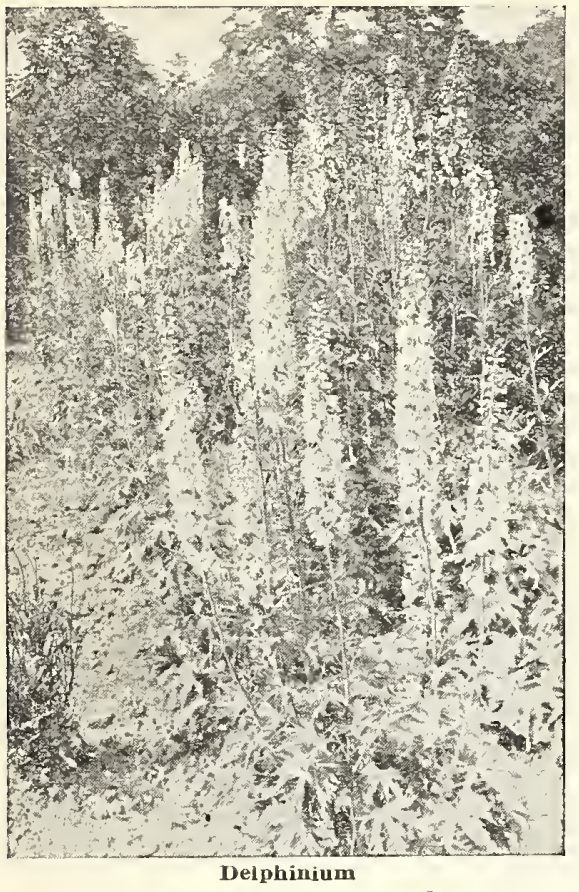

\section{DELPHINIUM}

These are the cream of all the perennials. Their blooming season covers nearly the entire summer. Our plants are strong 2 year old.

Belladonna-Sky blue. $25 \mathrm{c}$ each; 3 for $70 \mathrm{c}$.

Bellamosa-Dark blue. 25c each; 3 for $70 \mathrm{c}$.

English Hybrids-Gives you all colors from light blue to purple, in singles and doubles. $30 \mathrm{c}$ each; 3 for $80 \mathrm{c}$.

\section{DIGITALIS \\ Foxglove}

Flowers on stalks 3 to 4 feet, tall, very showy.

Purple or Rose 30c each; 2 for $50 \mathrm{c}$.

Dwarf Yellow-30c each; 3 for $80 \mathrm{c}$.

\section{GAILLARDIA}

\section{Blanket Flower}

Blooms all summer with long stems. Excellent for cutting, and has beautiful colorings. Center reddish brown, the petals are marked with rings of crimson and orange. $20 \mathrm{c}$ each; 3 for $50 \mathrm{c}$.

\section{GYPSOPHIL.A}

\section{Baby Breath}

Will thrive any place. When in bloom has an abundance of minute white flowers. One of the best to mix with other flowers in boquets. Can be dried for winter use. $25 \mathrm{c}$ each; 3 for $60 \mathrm{c}$.

\section{HIBISCUS}

Mallow Marvels

A very showy plant. Grows 4 to 5 feet tall and the flowers are 5 to 6 inches across. Your choice of colors, pink, white or red. $25 \mathrm{c}$ each; 3 for $70 \mathrm{c}$.

\section{LATHYRUS LATIFOLIUS}

\section{Perennial Sweet Pea}

Flowers large and full. Blooms almost all summer. Your choice of colors, red or pink. 20c each; 2 for $35 \mathrm{c}$.

\section{HELIOPSIS}

Hardy Zinnia

Bright Yellow Flowers. Fine for cutting. Foliage very desirable. $25 \mathrm{c}$ each; 3 for $60 \mathrm{c}$.

\section{LIATRIS}

Gay Feather

Cat-tail, Gay Feather. Flowers bright purple, borne on tail spikes. Grows $3 \mathrm{ft}, 25 \mathrm{c}$ each; 3 for $60 \mathrm{c}$.

\section{MYOSOTIS}

Forget-Me-Not

Alpine-Tiny blue flowers all summer. $30 \mathrm{c}$ each; 3 for $70 \mathrm{c}$.

\section{PAPAVER}

Oriental Poppy

Wirt's Black Orange-Orange colored petals with black at the base and black center. 3 yr. plants, 50c each. Royal Scarlet-Deep scarlet. $35 \mathrm{c}$ each; 3 for $\$ 1.00$.

\section{PHYSALIS}

Chinese Lantern Plant

Produces bright orange scarlet lantern-like fruits. Very fine for winter bouquets. Grows 2 ft. $20 \mathrm{c}$ each; 3 for $50 \mathrm{c}$.

\section{PLATYCODON}

\section{Balloon Flower}

Grows $2 \mathrm{ft}$. tall, with blue flowers which resemble small balloons about $1 \mathrm{r} / 2$ inches in diameter. $25 \mathrm{c}$ each; 3 for $70 \mathrm{c}$.

\section{PYRETHRUM}

Painted Daisy

Very hardy, blooms at intervals throughout the summer. Fine for cutting.

Mixed-Light shades. $25 \mathrm{c}$ each; 3 for $70 \mathrm{c}$.

\section{SEDUM}

Live For Ever

Spectabilis-Broad, bright green foliage, with inmense heads of rose colored flowers. Very showy. Fine for border planting. $20 \mathrm{c}$ each; 3 for $50 \mathrm{c}$.

\section{STATICE}

\section{Great Sea Lavender}

Latifolia-A valuable plant for border or rockery. Leaves have a leathery appearance, with purplish blue minute flowers on a tall stem. Can be dried and makes wonderful winter bouquets. $25 \mathrm{c}$ each; 3 for $70 \mathrm{c}$.

\section{ERYNGIUM Sea Holly}

Very showy plants with deep blue cones. Bloons in July and Aug. Grows about $3 \mathrm{ft}$. 25c each; 3 for $70 \mathrm{c}$.

\section{RUDBECKIA \\ Coneflower}

Newmani-Sonetimes called Black Eyed Susan. Deep orange flowers with dark purple cone for eye. Blooms all summer. $20 \mathrm{c}$ each; 3 for $50 \mathrm{c}$. 


\section{WIRT'S HARDU PERENNIALS}

\section{ALL PERENNIALS ARE SENT POSTPAID}

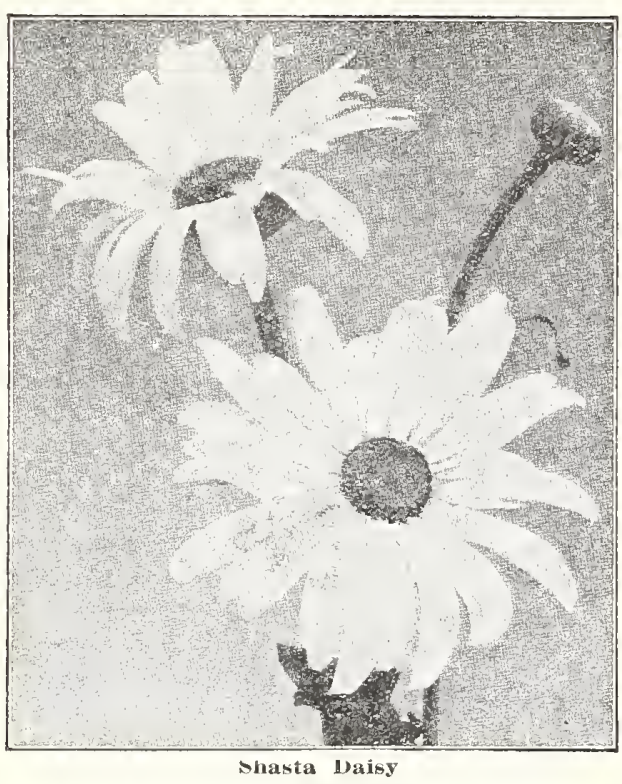

\section{SHASTA DAISY}

Alaska-An improved hardy white daisy, flowers snow white with yellow center. Excellent for cutting. 20c each; 3 for $55 \mathrm{c}$.

\section{HARDY OUTDOOR FERNS}

Do not bury Ferns too deep. Plant just deep enough so they are well covered. Put on top of them some moss, leaves, decayed manure or mulch. If you will observe Ferns in the northern woods you will find they grow and thrive in swamps with very little soil to support them.

8 Ostrich Plume Ferns 20 to 40 in.

8 Lady Ferns 10 to 18 in.

4 Onoclea Sensibilis 12 to 20 in.

20 Hardy Ferns.

One half the assortment

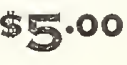

Any one fern for

(All Postpaid)

\section{$\$ 3.00$ \\ $50 c$.}

\section{HARDY LILIES}

Hardy Lilies are one of the most beautiful garden flowers that have been neglected. Planted in the spring 6 to 8 inches deep, they will bloom the same season and with a little covering they will come up again each year.

Auratum-(Gold Banded Japan Lily). This variety has ever been a great favorite. The flower heads are large, with broad petals gracefully recurved. White, thickly studded crimson-maroon, with a wide gold band down the center of each petal. Improves with age, and produces a vast amount of bloom. 35c each; 3 for $\$ 1.00$.

Elegans-This is a hardy and easily outdoor grown Lily. Produces a beautiful orange-scarlet bloom. Remains in bloom over a period of about two weeks. Plant in Spring. $25 \mathrm{c}$ each; 3 for $70 \mathrm{c}$.

Regal Lily-Single. New variety from western China. Hardy in all localities. Flowers are ivory-white striped on the outside with pink and splashed with canary-yellow at the base of the petals. Delightfully perfumed, stems 3 to 5 feet. $55 \mathrm{c}$ each; 3 for $\$ 1.50$.

Speciosum Rubrum-White spotted with rays of rosy red. Most satisfactory of all the Lilies. Mammoth size bulbs. Should be planted in the late Fall or early Spring. If planted in Spring, will bloom the same season. $35 \mathrm{c}$ each; 3 for $\$ 1.00$.

Tiger-This is a bright rosy red Lily, covered with black tiger-like spots. Grows 4 to 5 feet and blooms in August. Stands heat well and is a beautiful Lily to plant among the other shrubbery. Plant in Spring. 20c each; 3 for 60c; $\$ 1.75$ per 10 .

Lemon Lily-Flowers clear yellow, fragrant, free bloomer; very showy. 20c each; 3 for $50 \mathrm{c} ; \$ 1.50$ per 12 .

\section{PACHYSANDRA}

\section{Japanese Spurge}

A trailing plant used to cover shade places. Broad mats of bright glossy green foliage. Stays green most all winter. $30 \mathrm{c}$ each; 3 for $80 \mathrm{c}$.

\section{VIOLA}

\section{Hardy Pansies}

Mixed-One of the best all round perennials. Blooms from June until snow. We have picked Pansies after a snow storm. Not the common annual Pansy. 20c each; 3 for $50 \mathrm{c}$.

\section{YUCCA}

Adam's Needle

Broad, sword-like, evergreen foliage. Fine plants for lawn or rockery work. Tall spink of white flowers, in June. 3 yr. plants 30c each; 3 for $\$ 1.00$.

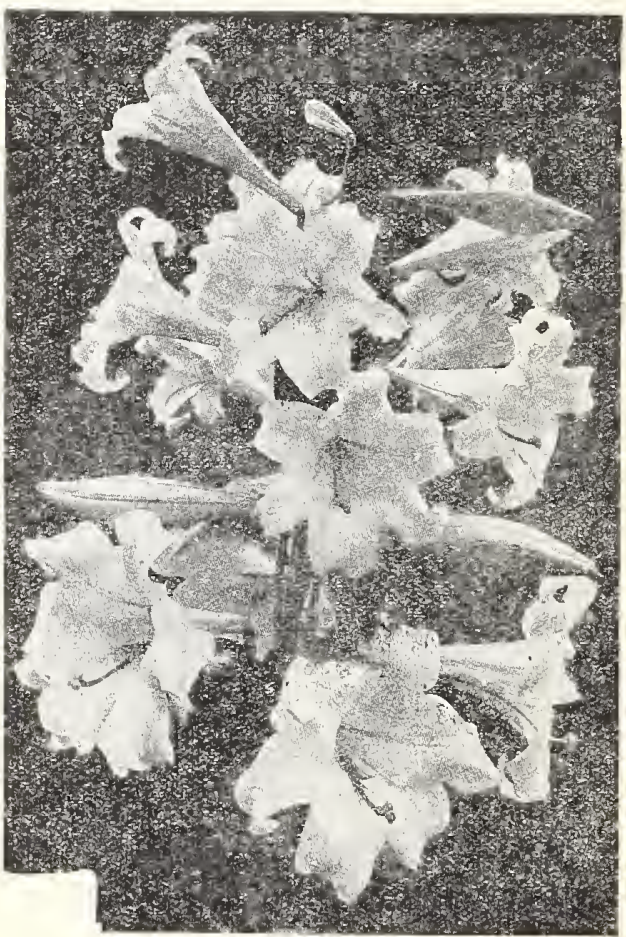

Regal Lily 


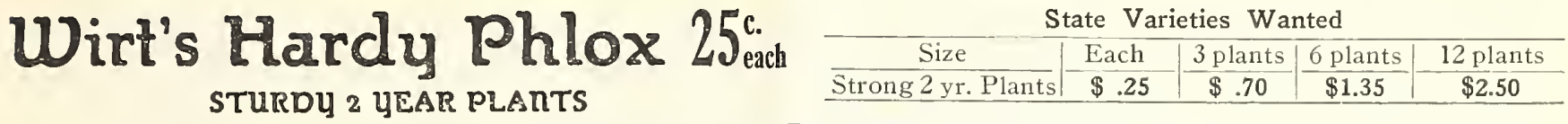 \\ ALL PERENNIALS ARE SENT POSTPAID}

The Phlox you will get from me have all bloomed once, showing they are hardy, sturdy stock, true to color. They are guaranteed to please. Plant 18 inches apart for immediate effect. They do well in partial shade. Are excellent among peony borders or iris. They come along after those flowers quit blooming. Will stand crowding. Phlox can be planted in the Fall or Spring.

Athis-Beautiful Salmon Pink. Beacon-Brilliant Cherry Red. B Comte-Rich dark purple.

Ferdinand Cortez-Coppery red.

Mrs. Chas. Door-Beautiful shade of lavender.

Miss Lingard-Earliest white, fine.

Rijnstroom-Bright Salmon Pink, immense flowers.

Rhinelander-Salmon Pink Claret eye.

Rising Sun-Beautiful shade of pink.

Sunset-Bright piik.

Wm. Ramsey-Deep dark red.

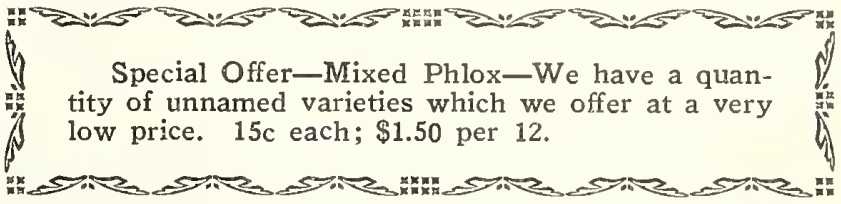

Fletcher-Delicate rose; very large and full. $45 \mathrm{c}$ each; $\$ 4.00$ per 12.

Special Collection No. 1

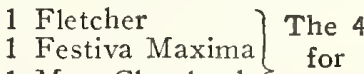

1 Mrs. Cleveland

1 Rose Fragrant $\$ 1.60$

Postpaid
Special Collection No. 2

We have a quantity of unnamed varieties of Pink Peonies, light and dark, early and late.

3 roots for $\$ 1.00$ Postpaid. all good, double flowering varieties.

Lucretia-Buds light pink, changing to white as flowers open; extra good grower and bloomer. $45 \mathrm{c}$ each; $\$ 4.00$ per 12.

Festiva Maxima-Inmense blooms, double, pure white, delicate tinge of cream in center and usually a few small flakes of crimson. The most popular peony grown. In great demand for cut bloom. An ideal white. $60 \mathrm{c}$ each. Floral Treasure-Delicate Shell Pink; rose type; fragrant; mid-season; blooms freely. 45c each; $\$ 4.00$ per 12.

Mrs. Cleveland-Very delicate pink, good bloomer. 45c each; $\$ 4.00$ per 12 .

Rose Fragrant-Light Red, very fragrant, late. $45 \mathrm{c}$ each; $\$ 4.00$ per 12.

Delicatessima-A Dark Pink, veıy double; Best for Decoration Day. 50c each.

\section{Wirt's Iris}

When you add to their extreme hardiness and ease of culture, the lavish display of blossoms, it is not surprising that they are highly prized. The charm of a bed of Iris is one of the keenest pleasures in June. Early varieties are always in bloom for Decoration Day. Later varieties prolong the blooming season.

\section{GERMAN IRIS, EARLY}

Caprice-Tinge of red, one of the newer varieties in German Iris. Grows 2 to 3 feet and a good bloomer. 20c each; $\$ 2.00$ per 12 .

Dwarf Blue-The variety grows 6 to 8 inches tall, the flowers are almost a dark purple, splendid for edging flower beds or walks. $15 \mathrm{c}$ each; $\$ 1.50$ per 12 .

Gertrude-Clear blue. The flowers are borne on tall stems, 2 to $2 \frac{1}{2}$ feet tall, three to four flowers to the stem. The foliage grows 1 to $1 \frac{1}{2}$ feet tall. $15 \mathrm{c}$ each; $\$ 1.50$ per 12 . Parsiensis-Deep purple. Grows same as above. The flowers are very large and very lasting. $15 \mathrm{c}$ each; $\$ 1.50$ per 12.
Extra Fine Red Peonies
Officinalis Rubra-Large, globular bloom; brilliant
crimson; this is the early flowering red peony so
common to the old time gardens; much used on
memorial day when other peonies bloom too late.
Fe each.
fouble; deep crimson, marked with cardinal at
base of petals. 75c each.
Francis Ortegat-Brilliant crimson. One of the
good red varieties. 75c each.

Aurea-Canary Yellow. Bloom a little later than the two above. The flower stems are 2 to 3 feet tall. Plant a very free bloomer. $15 \mathrm{c}$ each; $\$ 1.50$ per 12 .

Florentina Alba-Purple white. Flowers are very large; bornc on stem 2 to $2 \frac{\mathrm{T}}{2}$ feet tall; one of the best of the white. $15 \mathrm{c}$ each; $\$ 1.50$ per 12 .

\section{LATER VARIETIES}

Siberian Iris-White. Blooms in June, after the German Iris are gone. Foliage is 12 to 14 inches tall; dark green and very thick; the flowers are borne on stems 2 to 3 feet tall, pure white and of medium size. 15c each; $\$ 1.50$ per 12.

Japanese Iris-This variety of Iris is the last to bloom. Their blooms come the last of June and in July. They are tall growers and are of dark purple Gold and Mahogany shades. The flowers are extremely large, the largest of all Iris, many times measuring 6 to 8 inches across.

Gold Bound-White with Gold center, very fine and striking. $30 \mathrm{c}$ each; $\$ 3.00$ per 12 .

Mahogany-Beautiful mahogany color, very odd, good bloomer. 30c each; $\$ 3.00$ per 12 .

Purple and Gold-Purple petals with Gold center. This is a fine old standby variety in the Japanese. $30 \mathrm{c}$ each; $\$ 3.00$ per 12 . 


\section{Good, big
Roots}

Cannas are one of the finest of all season bedding plants. A wide range of colors in flowers and foliage. They serve to conceal the ground or make a back ground. They like plenty of sun and rich soil, with plenty of water.

\section{PAY THE POSTAGE ON ALL BULBS.}

Apricoi- (4 ft.) Broadly, compact trusses freely produced. Strong, rich apricot passing to silvery pink, with, gold and coral center. One of the daintiest and most attractive.

Shenandoah $-3 \mathrm{x} / 2 \mathrm{ft}$. Very compact, almost dwarf. Leaves bluish green; flowers very large; color pale pink with satin sheen.

The President-( $4 \mathrm{ft}$.) The best green-leaved, red-flowered canna offered. The flowers are immense, round, firm; a cherry one-color pure scarlet.

Wyoming-5 ft. Orange flowers, purple foliage.
King Humbert-Red. (4-4r/2 ft.) The best bronze leaved variety, very distinct heart-shaped leaves shaded with purple madder brown. Immense orchid trusses of velvety orange scarlet flecked with carmine, rose tinted at margin and base. Yellow King Humbert-4 ft. Has very large yellow flowers, softly spotted with bright red. Green leaves.

Eureka-(3 ft.) Full, broad trusses; uniform, free and continuous bloom. Clean, ivory white.

Bronze Bedder-6 ft. Bright red, bronze leaves. Tallest canna we have.

\section{Big Bulbs DAHLIAS 25each 3
for $60^{c}$ for $\quad \begin{gathered}6 \\ \text { for }\end{gathered}$ $12 \$ 2 \cdot 10$ \\ (excpt as noted)}

Dahlias are the most beautiful of fall flowers. Their immense size and wonderful colors make them very showy and attractive. Dahlias like the sun and lots of water. Plant the tuber about 6 in. deep, eyes or sprouts up. I pay the postage.

\section{Cactus Dahlias}

Countess of Lonsdale-Delicate apricot toward the edge of the petals. $35 \mathrm{c}$ each; 3 for $\$ 1.00$.

Genesta-Rich orange bronze.

Kreimhilde-Shell pink, shading to white at center.

Marion Thompson-Pure lemon yellow, very large.

Zephyr-Rosy pink, shading to heliotrope.

\section{Decorative Dahlias}

Delice-Glowing rose pink. Golden Sun-Golden yellow, lighter at center.

Jack Rose-Brilliant crimson rel.

Zulu-Dark velvety red.

\section{Show Dahlias}

Dreer's White-Pure white.

Ora Dow-Purple, tipped white.

Pearl Hilda-Pink.

Bon Ton-Deep garnet red.

\section{WIRT'S CHOICE}

Evelyn Kirkland-Beautiful shade of rosy pink, darker at the edges, fading to shell pink, darker at center; brilliant scarlet blotch on lower petals; long stems. Last year they reached over 50 inches. $15 \mathrm{c}$ each; $\$ 1.00$ per 12 .

Mrs. Frank Pendleton-A delicately flushed salmon pink. Each flower is strikingly marked with rich maroon blotch on the three lower petals. One of the most: exquisitely colored and formed Glads in our list. 10c each; $\$ 1.00$ per 12.

1910 Rose-A wonderful shade of pink. Very early bloomer. $10 \mathrm{c}$ each; $50 \mathrm{c}$ per 12.

Helen Franklin-Pure white with violet stripes on lower petals, slightly ruffled. A great Glad. 10c each; $\$ 1.00$ per 12.

Chicago White-Pure white with faint lavender streaks. Early. 10c each; 60c per 12.

Standard Mixture-Good varieties mixed. Recommended to those who desire good flowers without especial reference to color effect. Good size bulbs. 50c per 12 .

Carmen Sylva-A pure white Glad; very wonderful. 15c each; $\$ 1.50$ per 12 .

Schwaben- A giant yellow. None better. 10c each; 75c per 12.

Empress of India-Dark wine red with a black velvet throat. The flowers are placed even on the stem. One of the finest. $15 \mathrm{c}$ each; $\$ 1.50$ per 12 .

Mrs. Francis King-A bright scarlet. 10c each; 60c per 12. Muriel-A lavender spotted with white. An unusual color. $15 \mathrm{c}$ each; $\$ 1.50$ per 12 .

Baron J. Hulot-A dark velvet purple; bloom of medium size. $15 \mathrm{c}$ each; $\$ 1.50$ per 12 .

Anna Erberius-A velvety purple; throat deeper. A wonderful Glad; flowers large. $15 \mathrm{c}$ each; $\$ 1.50$ per 12.

Wilbrink-Delicate pale pink. 10c each; \$1.00 per 12.

Lily White-Pure white. 10c each; $\$ 1.00$ per 12.

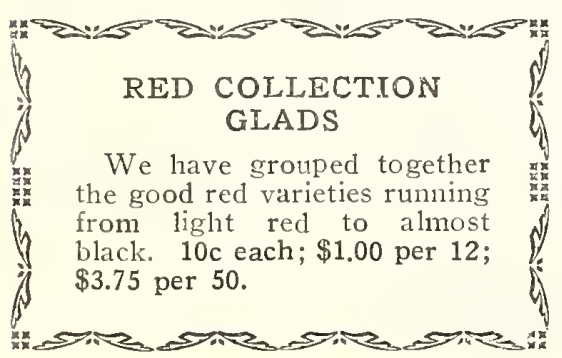

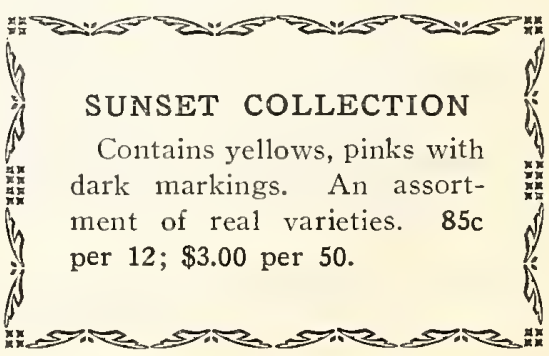




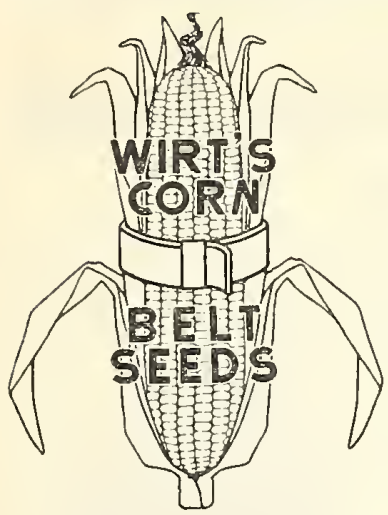

\section{SEED DEPARTMENT Wirt's High Grade Corn Belt Seeds}

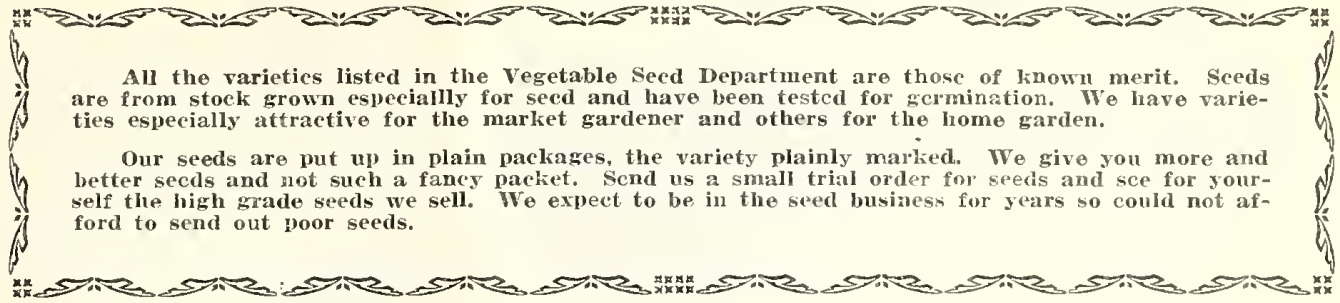

\section{ALL MY SEEDS ARE SENT POSTPAID}

\section{ASPARAGUS}

Plant the seed early, keep the weeds cleared out, with the rows any convenient distance apart. One ounce will sow 50 feet of drill. Paimetto-A very early maturing and prolific variety, producing an abundance of very large, deep green shoots of good quality. Packet, 10 ets.
cts., postpaid.

Washington-This variety is especially rust resisting, and we especially recommend it. This is decidedly the best variety for either the home garden or commercial planting. Plat, 10 cts.; oz., 32 ets.; $1 / 4$ lb., 90 ets.; $1 / 2$ lb., $\$ 1.65 ; 1 b ., \$ 3.00$, postpaid.

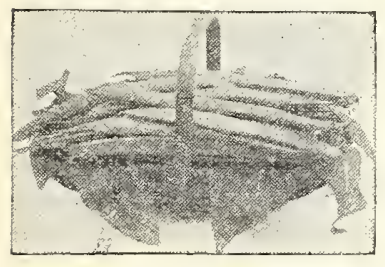

\section{BEANS}

\section{DWARF, WAX OR BUTTER}

Sow in rows 2 to 3 feet apart, plant about 8 inches apart in the rows. Cover about 2 inches. One pound of seed will sow 100 feet of row: one bushel $(60$ lbs.), to the acre.

Wirt's Rust-proof Golden' Wax-The pods are exceedingly handsome being of large size, very thick, and unusually fleshy. The quality is tender, brittle and entirely without strings or fibers at all stages until maturity, while the color is rich golden-yellow. There is no strain of Golden Wax that will excel the stock we offer. Packet, 10 ets.; $1 / 2$ lb., 22 cts.; H., 40 ets.

Early Prolific Black Wax-This improved strain of Black Wax we offer under this name is exceptionally productive, very hardy,
reliable and of the best quality. They are of a clear, light reliable and of the best quality. They are of a clear, light
golden yellow color and remain a long time in condition for use as snaps. I'acket, 10 ets.; $1 / 216 ., 22$ ets.; 1 b., 45 ets.

Davis Kidney Wax-A very showy variety and is largely grown for the canning factories. It has a long, straight pod of beautiful waxy color. Splendid yielder. Pacliet, 10 cts.; 1/2 1 b., 25 cts.; 1 b., 45 ets.

\section{DWARF GREEN PODDED VARIETIES}

These varieties are very rich in flavor and slightly hardier. Sow in rows 2 to 3 feet apart. Plant about 8 inches apart in the rows. Cover about 2 inches. One pound of seed will sow 100 feet of row; one bushel will sow an acre.

Burpeo's Stringless Green Pod-Plants grow from 12 to 15 inches high, very erect and productive. Pods round and about 5 inches long, absolutely st
25 cts.; 1 b. 45 ets.

Giant Stringless Green Pod-From its introduction it has been a favorite. Pods about 5 inches long. dark in color, very brittle and absolutely stringless. Tacket, 10 ets.; 1/2 Ib., 25 ets.; 1 b., 45 cts.

Bountiful-Pods beautiful rich green, very thick, broad, long and uniform; meaty, tender, fine quality; absolutely stringless. Good shell Bean for winter use. A splendid market variety. Packet, 10 ets.; $1 / 2$ 1b., 22 cts.; 1 b., 40 ets.

\section{POLE BEANS}

Pole Beans require more care than Bush Beans, but bear for a longer period and are generally more productive. Plant hills 2 to 3 feet apart and 3 or 4 beans in every hill. One-half pound to 100 feet of row; 30 pounds to the acre.

Famous Ircntucky Wonder or OId Homestead-Very early and enormously productive, the long green pods hanging in clusters from top to botom of pole; entirely stringless. Pods of a silvery green color. Packet, 10 cts.; 1/2 lb., 22 cts.; lb., 40 cts.

White Dutch Case Innife-Pods become creamy white as they mature. Of excellent quality, whether used gleen or dry. Paeket, 10 cts.; $1 / 2$ lb., 22 cts.; lb., 40 cts.
Lazy Wife-Each pod contains from 6 to 8 white beans, which make excellent winter shell beans. Thacket, 10 cts.; 1/2 lb., 25 cts.; 1 b., 45 cts.

\section{LIMA BEANS}

Burpee's Improved Bush Lima-Vigorous, large size, the single Beans of Burpee's Improved, very large and of better quality than the original Burpee's Bush Lima. Packet, 10 cts.; 1/2 lb., 25 cts.; 1b., 45 cts.

IIenderson's Bush Lima (Baby Lima)-One of the smaller-seeded sorts but the most prolific of all the Bush Limas. Somewhat earlier than the other varieties and bears all the time. Packet, 10 cts.; 1/2 lb., 22 ets.; lb., 40 ets.

Fordhook Bush Lima-This newest and best Bush Lima represents the highest achievement in bean breeding and we offer our patrons. in our Improved Strain of Fordhooks, a Bush Lima that has atained the acme of perfection, surpassing any other strain or type on the market. It is the best possible Bush Lima Bean, possessing every quality so long known and esteemed in the older pole varieties, and can be grown as eaviy as any Snap Bean. Packet, 10 ets.; 1/2 1b., 27 ets.; 1 b., 50 ets.

King of the Garden (Pole Lima)-Simewhat later than the Bush Limas, but very prollic ded. The pods frequently contain 5 to 6 very large beans. Beans of excellent quantity, easily shelled; of large size and handsome appearance. Packet, $10 \mathrm{cts}$; $1 / 2 \mathrm{lb.}, 22 \mathrm{ets}$.; $1 \mathrm{b.}, 40 \mathrm{cts}$.

\section{BEETS}

\section{TABLE VARIETIES}

Rich soil is very important in growing table Beets. Plant the seed as early as possible and dig young. Do not allow them to become overgrown.

Detroit Dark Red-Very early; medium size; globe-shaped; dark red skin. Pacliet 8 ets.; $0 z ., 15$ cts.; $1 / 4$ lb., 35 cts.; $1 / 2$ lb., 60 ets.; lb., $\$ 1.10$.

Early Blood Turnip Beet-Our standard variety with bright red flesh. It is a good keeper. Packet, 7 cts.; 0z., 13 cts.; 1/4 1b., 30 ets.; $1 / 21 b ., 50$ cts.; 1 b., 90 ets.

Crimson Globe-Same as Detroit Dark Red only a lighter shade of red. Slightly zoned with white. Packet, 8 cts.; oz., 14 cts.; 1/1 lb., 35 ets.; 1/2 Ib., 60 cts.; Ib., $\$ 1.10$

Crosby's Egyptian-An early variety of bright red color; tender and of fine quality. Very uniform in size. Facket, 8 ets.; 0z., 15 cts.; $1 / 1$ lb., 35 ets.; $1 / 2$ lb., 60 cts.; 1 b., $\$ 1.10$

Swiss Chard or Spinach Beet-Cooked like spinach greens. The leafy portion of Swiss Chard is of most excellent flavor. Packet, 7 cts.; oz., 15 cts.; 1/4 ib., 38 ets.; 1/2 1b., 65 ets.; $16 ., \$ 1.25$.

\section{CRESS}

Curled or Peppergrass Cress-This small salad is much used with lettuce to the flavor of which its warm, pungent taste makes a most agreeable addition. Packet, 5 ets.; oz., 10 ets.; 1/4 Ib., 35 cts.

\section{RELIABLE}

\section{CAULIFLOWER}

Henderson's Early Snowball-The seed we offer you is of the highest possible quality "Grown in Denmark," the country from which it was first introduced. The strain we offer is the result of thirty years breeding and perfecting by the most honorable and responsible grower in Denmark. Packet, 15 cts.; 1/4 oz., 65 ets.; 1/2 oz., \$1.20; oz., $\$ 2.25$; $1 / 1$ lb., $\$$ \%.50.

New Dry Weather-Is especially adapted to dry situation and to reist droughts like all other Cauliflowers, it requires manure and culture; but it will succed with less rainfall than any other variety. Packet, 12 cts.; $1 / 2$ oz., $\$ 1.10 ; 0 z ., \$ 2.00 ; 1 / 2$ lb., $\$ 7.25$.

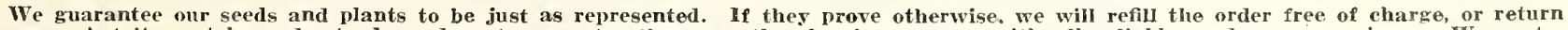

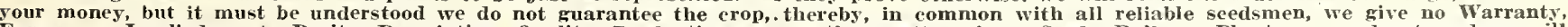

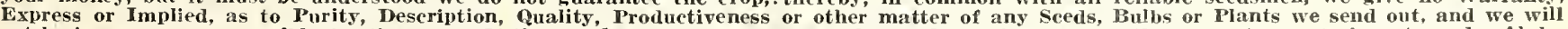

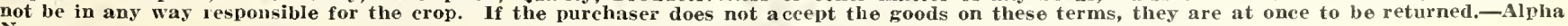
Nursery. 


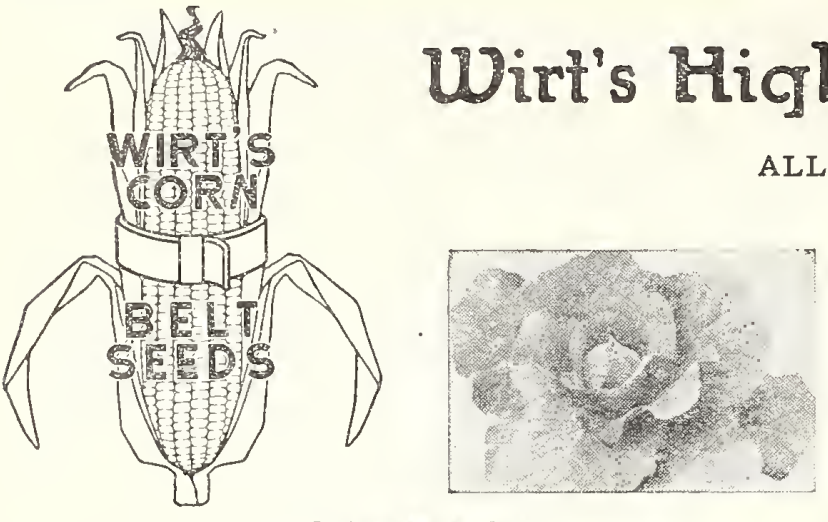

CABBAGE

Prize Surelıead-Sureness in heading and regularity in growth have placed this at the top of the list, and we have no fear of using words of praise too high for its merits. Nobody will be disappointed in our strain, for it represents the best principles of seed culture applied. Pacliet, 7 cts.; oz., 22 cts.; 1/4 1 b., 75 cts.

Wirt's Prosperity-The Best Second Farly-Prosperity is yours if you plant an acreage of this grand cabbage. Very earliest, largest and best flat headed cabbage we have ever seen. It forms large flat heads, solid as marble, weighing 16 to 20 pounds each. The most popular of all Summer Cabbage. Truly this might be termed The All Year Around Cabbage. Wirt's Prosperity is a dwarf, compact grower with few outer leaves, allowing very close planting, a sure header, very uniform in growth, beautiful appearance, free from coarse leaves. Packet, 15 cts.; 1/2 oz., 35 cts.; oz., 60 cts.; $1 / 41 b_{*}$ $\$ 2.00$.

All Seasons-An excellent second early cabbage, producing large, solid heads of uniform shape, flattened on top, Packet, 7 ets, ; oz. 22 cts.; $1 / 41$ 1b., 75 cts.

Large Late Drumhead-It makes a large, round, firm head, uniform in shape and color, which seldom bursts or rots. It is a standard sort for winter keeping and sells readily in the winter and spring markets. One of the most profitable varieties to grow, and will give unbounded satisfaction. Packet, 7 cts.; $0 z ., 25$ cts; $1 / 41$., 75 cts. Wisconsin No. 8-Developed out of Hollander under the direction of Dr. L. R. Jones of the University of Wisconsin. At Racine, Wis., where for several years many of the commercial crops of cabbage where badly infected or entirely destroyed by the disease called the were badly infected or entirely destroyed by the disease called the tack. Packet, 15 cts.; $1 / 2$ oz., 55 cts.; 0z., $\$ 1.00 ; 1 / 416 ., \$ 3.25$.

Mammoth Prize Late Flat Dutel-Prize Flat Dutch is comparatively free from a disposition to burst, and is one of the most reliable winter keepers. Packet, 10 cts.; $0 z_{.}, 27$ cts.; $1 / 4$ 1b., $80 \mathrm{cts}$.

True Genuine Danisl Ballhead-This celebrated Cabbage is now recognized the world over as the hardest headed, Longest keeper, best shipping and biggest money maker of all winter varieties. Packet, 10 cts.; oz., 32 ets.; 1/4 lb., 90 cts.

Early Jersey Wakefield-The best first early, oblong sort. Heads are conical, very hard and solid, and of excellent quality. Most
gardeners depend upon it for the bulk of their extra crop, and its gardeners depend upon it for the bulk of their extra crop, and its hardiness to resist cold and other unfavorable conditions insures the
most satisfactory results. Packet, 10 cts.; 0 z., 32 cts.; 1/ 1b., 90 cts.

\section{CHINESE CELERY CABBAGE}

"Wog Bok"-Very earliest dwarf sure header. A new vegetable introduced into this country from China. We offer only imported Chinese grown seed, which is reliable for good bunching heads. Packet, 10 cts.; oz., 35 cts.; $1 / 1$ lb., \$1.05.

\section{CELERY}

Golden Self-Blanching-The best market variety, especially for early crop. The plant is naturally golden yellow (both stem and leaves), but needs to be blanched to make it brittle, and fit for table; rather small bunch. Packet, 12 cts.; oz., 60 cts.; $1 / 41$ lb., $\$ 1.80$.

White Plume-Matures in 100 days. Unlike most varieties, this one does not require to be earthed up, but if only loosely tied, and a few handfuls of earth brought close around the base of the leaves to keep them close together, all the inner leaves or thin stalks will turn white and crisp. Packet, 10 cts.; $0 z ., 30$ cts.; 1/4 1b., 90 cts.

\section{CARROTS}

New Early Chantenay-A very fine variety for bunching. This is a very choice strain, producing thick roots of the finest quality. Will average three inches in diameter at the shoulder, gently tapering throughout the broad stump-root, and measuring five inches in length. Flesh tender, flne grained, free from hard core, and of a deep golden orange. An excellent variety to grow for winter use, deep golden orange. An excellent variety to grow for winter use, Packet, 10 cts.; oz., 16 cts.; 1/4 1 b., 34 cts.; 1/2 lb., 55 cts.; lb., $\$ 1.00$.
Gueraude or Oxheart-A good variety on soils too hard and stiff for the longer-growing sorts. The root is short, very thick and has a small tap root: flesh is a bright orange flavor. Packei, 10 cts.; oz., 16 cts.; $1 / 4$ lb., 34 cts.; $1 / 2$ lb., 55 cts.; lb., $\$ 1.00$.

\section{CUCUMBER}

Early Fortune-An exceptionally fine early and productive Cucumber; an improved strain of the White spine. Packet, 10 cts.; oz., 15 cts.; $1 / 4$ 1b., 35 cts.; Jb., \$1.25.

Chicago Pickling-Snall variety used extensively for pickling; prolific. Packet, 10 cts.; oz., 12 ets.; $1 / 216 ., 32$ cts.; 1b., \$1.00.

Long Green-One of the earliest long green varieties, fruit 10 to 12 inches long, and of a rich dark green color; fine for shipping; also a good pickling variety when young.

Arlington White Spine-An old timer and a good one. Packet, 7 cts.; oz., 14 cts.; $1 / 41 b ., 32$ ets.; $1 / 2$ lb., 55 cts.; lb., $\$ 1.00$, postpaid.

\section{EGG PLANT}

New York Improved Spineless-This is an entirely spineless strain of the large purple-fruited, which is the well-known standard. The plants are equally as productive, fruits as large and well colored, but stems and calyx are entirely free from spine. Packet, 10 sts.; $1 / 2$

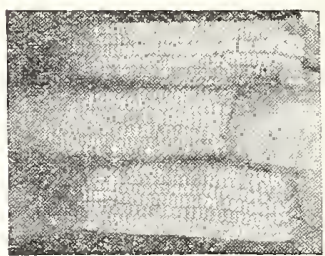

\section{SWEET OR SUGAR CORN}

Golden Bantam-It is not only the sweetest, but also one of the hardiest, and what it lacks in size is more than made up by its other qualities. The ears are from six to seven inches long, eight rowed, filled with broad, sweet, golden yellow kernels of a delightfui flavor. It may be planted with perfect safety from ten days to two weeks earlier than the Sweet Corns. The dry seed is quite solid and is not apt to rot as that of the softer kinds. Packet, 10 cts.; 1/2 1 b., 20 ets.; 1b., 35 cts. Adams Extra Early-We handle only the earliest dwarf strain of this variety. It is not a Sugar Corn, but produces ears well filled with tender, white grains. If you want the first Sweet Corn on the market or table, plant this stock. Packet, 5 cts.; 1/2 1b., 15 ets.; lb., 25 cts.

Stowell's Evergreen-This is one of the most popular of all varieties. Although not an early sort, it is without exception the best for table use of the entire lot. Some may have tried it, but did not have pure stock as no variety degenerates so quickly unless the grower is ex ceedingly careful. Packet, 10 cts.; 1/2 lb., 20 cts.; lb., 35 cts.

Country Gentleman-The ears average 9 inches in length and are borne from two to five and sometimes six on each stalk. The cob is small and very closely packed from tip to butt with slender, pure white kernels of the finest quality. If you try this variety you will like it. Packet, 10 cts.; 1/2 1b., 20 cts.; 1 b., 35 cts.

\section{LETTUCE}

Simpson's Early Curled-A very extensively used early loose-leaved, or clustering frilled and much bilstered, crisp, sweet and tender. The sort is especially adapted for sowing thickly and cutting when the plants are young. Packet, 8 ets.; oz., 15 ets.; 1/4 1b., 40 ets.; 1/2 lb., 70 ets.; lb., \$1.30.

Black Seeded Simpson-One of the best for sowing outdoors where an exceedingly tender leaf is desired and for those markets which demand a very large loose clustering sort. This curly and thindemand a very large loose clustering sort. This curly and thincellent quality a very long time. Packet, 8 cts.; oz., 18 cts.; 1/4 lb., 45 cts.; $1 / 2$ lb., 80 cts.; 1 b., $\$ 1.50$.

Grand Rapids-Produces loose heads of large size and handsome appearance, and is crisp and tender as any lettuce can be. The leaves are bright green and crimped at the edges. One of the most popular varieties on the market, easily raised out-of-doors, from early spring planting. Ideal for the home garden and for town and city markets. planting. Ideal for the home garden and for town and city markets. Grand Rapids is used almost altogether for forcing under glass. 


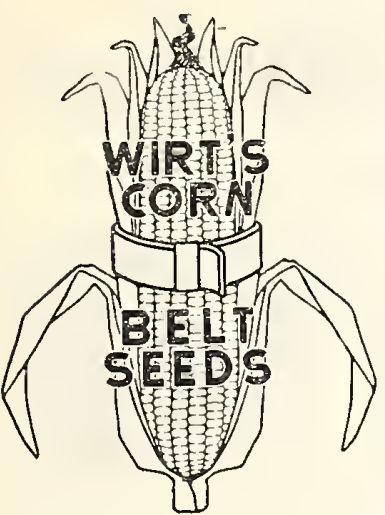

Wirt's High Grade Corn Belt Seeds

\author{
ALL MY SEEDS ARE SENT POSTPAID
}

\begin{abstract}
LETTUCE-Continued
\end{abstract}
Early Prizehead-Very attractive variety of loose heading type. Makes qulck growth of bright green leaves, tinged with brownish red. Good flavor, crisp and tender. Quite hardy, making good kind for early planting. Packet, 10 ets.; oz., 18 ets.; 1/4 lb., 45 cts.; 1/2 Ib., 80 ets.; 1 b., $\$ 1.50$.

May King-Produces round, solld head about six inches in dlameter with leaves smooth and folded close. Plants are of quick growth and quallty all that can be desired -probably best of smooth-leaved early kinds; very rich and fine, 18 ets.; $1 / 4$ lb., 4 a ets.; $1 / 21$ lb., 80 cts.; 1b., $\$ 1.50$.

Big Boston-Largely grown under glass during winter as it produces large heads, which often measure one foot across. Also ideal outof-doors variety. Heads large, compact and the leaves are tender, crisp and of delicious quality, and taking it, one variety with another, we believe it about the best of all. Big Boston ls one of the hardiest varleties of lettuce and is used for out-door winter-culture in the southern states.

Packet, 10 ets.; oz., 18 ets.; 1/4 lb., 45 ets.; $1 / 2$ lb., 80 ets; Ib., $\$ 1.50$.

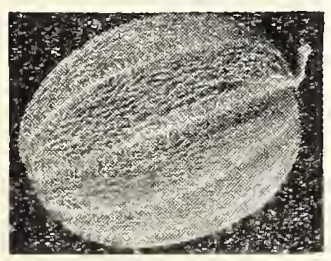

\section{MUSKMELONS}

Hearts of Gold-The best early salmon flesh melon and a wonderful money maker. Just the right size to cut in halves and serve alone or with ice cream. Flesh is deep orange, extremely thick, fine grainor and as sweet as honey. Always free from stringiness-closely netted - very solid - almost blight proof. We never have enough of
der early please. Packet, 10 cts.; oz., this seed to go around, so order early please.

New IIoney Sweet-This new strain represents the cream of the Nutmegs, particularly for localities subject to rust Our efforts for several years have been to combine all the desirable features of the newer and best productions at Rocky Ford into one grand variety which you will find ln Honey Sweet. Packet, 10 ets.; oz., 16 ets.; 1/4 Ib., 35 ets.; $1 / 2$ lb., 65 ets.; 1 b., $\$ 1.25$.

Improved Rocky Ford-( 70 days). Does well in most any locality. Very productive, medium early. Flesh is green and very sweet. Vines are very vigorous. One of the best for home use. Packet, 6 ets.; oz., 12 ets.; 1//1 lb., 30 ets.; 1/2 lb., 55 ets.; lb., $\$ 1.00$.

Osage or Miller's Cream-( 80 days). Larger than E'merald Gem, having thick, firm, orange flesh of fine quality. One of the best yellowmeated sorts. Packet, 8 ets.; oz., 14 ets.; $1 / 4$ lb., 35 ets.; $1 / 2$ lb., 65 cts.; 1b., \$1.25.

Extra Early IIackensack- (65 days). Fruits round and flattened at the end. Very heavily netted and irregularly ribbed. One of the best early green-meated sorts. Melons weigh 4 to 10 pounds. Packet, 6 ets.; oz., 10 ets.; $1 / 1 / 1$ lb., 30 ets.; 1/2 lb., 55 ets.; 1 b., $\$ 1.00$. Banana Cantaloupe- ( 85 days). The flesh of this melon is very solid, rich salmon color, of mighty good flavor when the melon is thoroughly ripe. Grows from 20 to 30 inches in length and is very prolific; very peculiar in appearance. Packet, 10 ets.; oz., 18 ets.; prolific;
$1 / 4$ lb., 45 ets.; $1 / 2$ lb., 80 ets.; 1 b., $\$ 1.50$.

\section{WATERMELONS}

Irish Grey-It's sweet; the flesh is red, crisp and free from stringi. ness and in color of rind a mottled greenish grey, entirely distinct. Rind is thin but very tough. Packet, 5 cts.; oz., 12 ets.; 1/4 lb., 30 ets.; 1/2 Ib., 55 ets.; lb., $\$ 1.00$.

Tom Watson-Matures in 85 days. The South's most popular, big, sweet watermelon, dark green in color. Melons are long, average large size, splendid shippers and one of the best table quality melons on the market. Our stock is grown for us with great care on a large plantation where no other melons are planted. Packet, 7 ets.; oz., 12 ets.; 1/4 Ib., 25 ets.; $1 / 2$ lb., 45 ets.; lb., 80 ets.

Ice Cream or Peerless-White seeded; of unquestionable quality; very early; medium size, thin rind, flesh bright scarlet. Rind too thin for shipping, but it is the great home market melon. Few, if any, sorts surpass it in melting, delicious quality. Packet, 7 cts.;

Kleckley's Sweets or Monte Cristo-We get our seed of thls wonderful melon direct from the originator, Mr. Kleckley, which is the only true stock. Matures in 80 days. One of the earliest melons to rlpen and one of the sweetest and best flavored. It is hard to beat; 1s splendid for home use and market. Large size, handsome appear- ance and superior quality. Melons grow 18 to 24 inches 1 ln length and 10 to 12 inches through; rind dark green; flesh bright scarlet, with broad solid heart, extra sweet, melting and crisp, being en-
tirely free from stringiness. Packet, 8 ets.; 0z., 15 ets.; 1/4 lb., 30 cts.; $1 / 2$ lb., 55 ets.; 1 b., $\$ 1.00$. Georgia Rattlesnake, or Striped Gypss-Matures ln 85 days. Of large
size, light green, with large, dark stripes. Fine market variety. It stands transportation better than most other kinds; a favorite with market gardeners. The seed we offer of this variety is grown especially for us. Packet, 5 ets,; oz., 12 ets.; 1/4 lb., 28 ets.; $1 / 21$ lb., 50 ets.; lb., 95 ets.

\section{PARSNIPS}

Hollow Crown-Rich, very sweet flavor, immensely productive, ready for use in 80 to 85 days. Roots are smooth, in good soil 15 inches long by 3 inches across the shoulder; tender and sugary. Packet. 10 cts.; oz., 15 cts.; $1 / 4$ lb., 35 cts.; lib., $\$ 1.25$.

\section{PARSLEY}

Moss Curley-Standard variety; curled leaves; finest quality. Packet, 10 cts.; oz., 18 ets.; 1/4 lb., 35 ets.

\section{ONIONS}

Prizetaker-A very satisfactory onion to grow for seed planting. Much larger than Globe Danvers under ordinary condltions. Wlli mature in 130 to 140 days. Packet, 10 ets.; oz., 25 ets.; 1/4 lb., ro cts.

Southport Yellow Globe-Flesh white, mild flavor, large in size and an excellent keeper. Packet, 10 ets.; oz., 18 ets.; 1/4 lb., 60 ets.

Southport Red Globe-Just the right size to command highest market price. Darker skin and better keeper than any other strain of Southport. Fixcellent keeper. Packet, 10 cts.; oz., 20 ets.; 1/4 lb., 6.5 cts.

Southport White Globe-Differs from other Southports in color only. Slrin pure white. Packet, 10 ets.; oz., 32 ets.; $1 / 4 \mathrm{lb.}$.\$1.00.

\section{PEPPERS}

Ruby King-Matures in 120 days. An exceedingly large and handsome pepper of mild flavor; the peppers are of a bright ruby red, from 412 to 6 inches long, by 9 to 12 inches in circumference. Can be sliced to and cucumbers. Packet, 10 ets.; $1 / 2$ oz., 25 cts.; oz., 40 cts.; 1/4 Ib., $\$ 1.25$.

Sweet Mountain-One of the large sorts. Very thin skinned, sweet and mild flavored; much used for stuffed pickles. Packet, 10 ets.; $1 / 2$ oz., 25 ets.; oz., 40 ets.; $1 / 4$ Ib., $\$ 1.15$.

\section{POP CORN}

Australian Hulless-Also known in some sections as Japanese Rice, Tom Thumb, or Bumble Bee Popcorn. The Australlan Hulless is a dwart-growing corn, a heavy yielder of attractive ears, peculiar in $1 / 2 \mathrm{lb}, 20$ ets.; lb., 25 ets.

\section{PEAS}

Alaska-Very desirable pea for market, dark green pods, and good shipper. Packet, 10 cts.; 1/2 lb., 22 ets.; lb., 40 ets.

American Wonder-The earliest wrinkled pea. Vine 10 to 12 inches high. Very prolific; excellent flavor. Recommended for family use. Packet, 10 ets.; 1/2 1b., 22 ets.; 1 b., 40 ets.

Little Gem-An early dwarí pea for market and famlly use. Pods large and crowded with 6 to 9 peas. A little dwarf pea for canners. Packet, 10 ets.; 1/2 lb., 20 cts.; lb., 35 cts.

Little Marvel-Vines grow yery even, about 15 inches hlgh, bearlng good sized pods. frequently in pairs. Good seller on all markets. Packet, 10 ets.; 1/2 lb., 25 cts.; lb., 45 ets.

Nott's Excelslor-One of the most popular varieties for the home garden. Is also very desirable for the market gardener. Pods are well filled and peas

Alderman-This fine new pea is of the Telephone type excepting the pods are of darker color. Highly recommended to market gardeners as a splendid yielder. Packet, 10 cts.; 1/2 lb., 25 ets.; Ib., 45 cts.

\section{PUMPKINS}

Big Tom-A greatly improved strain of Yarkee or Connectlcut Field Big rom-A greatly improved strain of Yarkee or connecticut most Pumpkin whlch has been selected for many years to secure the most the yield is nearly double that of the old variety. We recommend lt to our customers as the very best type of cornfield pumpkin. 


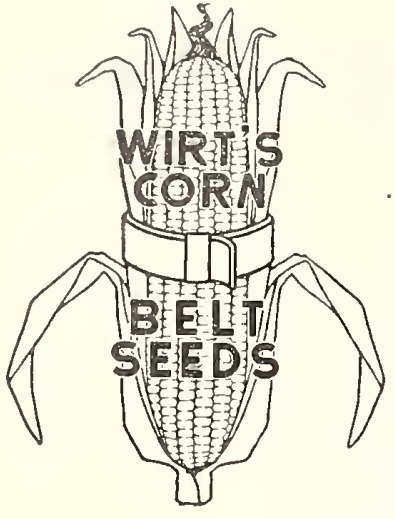

\section{Wirt's High Grade Corn Belt Seeds}

\section{ALL MY SEEDS ARE SENT POSTPAID}

\begin{abstract}
PUMP1KNS-Continued Sugar Pie-Fruits of small size, averaging about ten inches in diameter, of excellent keeping qualities; flattened or slightly ribbed. Skin deep orange-yellow; flesh very sweet, fine grained and most excellent for pies. Packet, 8 cts. oz., 12 cts.; $1 / 1$ 1b., 30 cts.; $1 / 2$ lb.; 55 cts.; 1b., \$1.00.

Winter Iuxury-Fine keeper and enormously productive. Color, enormously productive. Color, 14 cts.; 1/4 lb., 35 cts.; 1/2 lb., 65 14 cts.; $1 / 41$ lb., 35 cts.; $1 / 2$ lb., 6.9
cts., 1 lb., $\$ 1.25$.
\end{abstract}

\section{RADISHES}

White lcicle-Radishes measuring from 4 to 5 inches long and onehalf to three-fourths inch thick. Earlier than any other long white radish, pure white, almost transparent, very tender. Packet, 7 cts.; oz., 14 cts.; 1/4 Ib., 28 cts.; 1/2 lb., 50 cts.; lb., 90 cts.

Long Scarlet-Tops rather small; roots long and tapering; an intense bright scarlet; very crisp and tender. When grown rapidly is free from pungent taste. Ready for use in 25 to 28 days. Packet 5 cts.; oz., 10 ets.; $1 / 4$ lb., 25 cts.; $1 / 2$ lb., 45 ets.; lb., 85 ets.

French Breakfast-Matures in 22 days. A handsome radish, scarlet, with the end and the root white. Quite tender. Packet, 7 cts.; oz. 12 ets.; 1/4 1b., 25 cts.; $1 / 211_{*}, 45$ cts.; $1 b_{.}, 85$ cts.

Vicks Scarlet Globe-One of the best for forcing or for early outdoor sowing. Perfect in shape and color. Roots are oval or olive-shaped, deep scarlet in color, mild, crisp and tender flesh. Small tops. They are ready for market in 20 to 25 days after sowing. Pucket, 6 cts.; oz., 12 ets.; 1/4 lb., 25 cts.; 1/2 lb., 45 cts.; lb., 85 cts.

Royal Gem-Matures in 20 days. A very early radish, quite popular with market-gardeners. A beautiful. deep scarlet color, with white tips; small tops. Selected stock. Packet, 10 ets.; 8 oz., 18 cts.; $1 / 4$ lb., 40 cts.; $1 / 2$ lb., 65 cts.; 1 b., $\$ 1.25$.

California Mammoth Winter-Large white winter variety. Packet, 7 ets.; oz., 14 cts.; $1 / 4$ lb., 28 cts.; $1 / 2$ lb., 50 cts.; lb., 90 ets.

\section{SALSIFY}

\section{OR VEGETABLE OYSTERS}

Mammoth Sandwich Island-Improved type, producing roots of extra large size, superior quality, delicate flavor. Packet, 10 cts.; oz., 22 cts.; $1 / 4$ lb., 65 cts.

\section{SPINACH}

Bloomsdale or Savoy Leaf-An early variety and one of the best varieties to plant in the Autumn for early Spring use. Narrow pointed deep green leaves which are slightly curled. Packet, 5 cts.; oz., 10 cts.; $1 / 41$ b., 17 cts.; 1/2 lb., 28 ets.; lb., 50 cts.

\section{SQUASH}

Yellow Summer Crookneek Squash-Standard Summer variety, small crookneck. Early, productive. Packet, 8 ets.; oz., 14 ets.; 1/1 1b., 35 cts.; $1 / 21 \mathrm{~b} ., 65$ cts.; $1 \mathrm{~b} ., \$ 1.25$.

IIubbard-This is the well known Winter Squash now grown so largely throughout the country. Vines of strong running growth; fruits large, olive shape, with dark green skin and very rich fiesh. An excellent keeper. Packet, 10 cts.; oz., 18 cts.; 1/4 lb., 45 cts.; 1/2 lb., 80 cts.; lb., \$1.50.

Table Queen or “Des Moines'-A comparatively new variety. Market gardeners have found it their best seller. The enthusiasm of customers entitles it to the place among Squashes accorded to "Golden Bantam" in Sweet Corn. Table Queen is just the right size to serve two persons. Packet, 10 cts.; oz., 18 cts.; $1 / 41$ lb., 55 cts.; 1/2 lb., $\$ 1.00 ; 1 b ., \$ 1.75$.

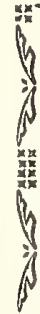

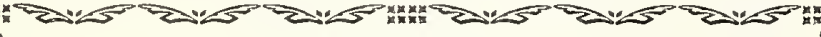

\section{LAWN GRASS SEED}

Wirt's Lawn Grass Mixture-This is a good grade of grass seed, and not to be compared with the cheap package seed.. 50c per $1 \mathrm{~b} . ; 3 \mathrm{lbs} ., \$ 1.45 ; 10 \mathrm{lbs} ., \$ 4.75$. Postpaid.

Wirt's Shady Lawn Grass Mixture-This sced is blended especially to build up a lawn vulere shade is to be considered This seed is for sowing under trees and shady places where the olingry fecd docs not suceed well, sac places lbs. $\$ 1.60 ; 10 \mathrm{lbs}$. $\$ 5.00$; amount of to $400 \mathrm{sq}$. $\mathrm{ft}$., or double this amount if quick lawn is wanted.

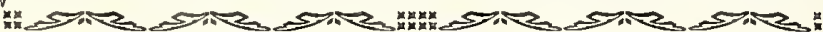

\section{TOMATOES}

Our seed is selected from tomatoes that have been grown and selected for seed only. Sow the seed in March and April in hotbed or in pot in a sunny exposure, in the house. If stock plants are desired they may be stock plants are desired they may be transplanted into a cold frame or greenhouse when 2 or 3 inches high. the ground has become warm, transplant into the open.

Earliana-Very popular extra early sort. Plants are of compact growth and yield well. Fruit solid, fine quality, and bright red. Ready for market in 90 days. Packet, 10 ets.; $0 z ., 35$ cts.; 1/4 1b., 85 cts.

New Stone-This variety has obtained immense popularity with mar ket gardeners, southern growers, canners and home growers everywhere. Its solidity and carrying qualities are remarkable. Its color is a desirable red, its shape is exce

Marglobe-A Wonderful New Variety-A cross between Livingston's Globe Tomato and a French variety by the name of Marvel. It is a bright red variety not only on the surface but all the way through. It is about the size and shape of Livingston's Globe. One of the best features is that it is resistant to wilt and nail head rust disease. An excellent shipping and market variety. Has very small core. Packet, 15 cts.; oz., 50 cts.; 1/4 lb., $\$ 1.85$.

Ponderosa-Exceptionally large in size. It must have rich soil to be a success, but fruits are very large, purplish pink in color, solid, meaty and very sweet. Packet, 10 ets.; 1/2 oz., 35 cts.; oz., 60 cts. $1 / 1 / 1 \mathrm{lb}, \$ 1: 60$.

Yellow Pear-Largely used while green for pickles and preserves, also for preserving after ripe; this is a very prolific variety and does well in any of the Tomato-growing states. Packet, 10 cts.; 1/2 oz. 30 cts.; oz., 50 cts.

\section{TURNIPS}

Turnips do the best in a highly enriched or sandy loamy soil One ounce will sow 125 feet of drill; 2 lbs. per acre in drills; 3 lbs. broadcast.

Early Purple Top Strap-Leaved-A quick grower. Flesh is fine grain and sweet flavor. Planted largely for table use. May be sown broadcast or in drills. Forms good sized bulbs in 7 to 8 weeks. Packet 5 cts.; oz., 10 ets.; $1 / 11$ lb., 20 ets.; 1/2 lb., 38 ets.; 1 lb., 70 ets.

Purple Top White Globe-One of the handsomest and most salable turnips. Desirable for either home or market. Flesh pure white, fine grain; of excellent flavor. Splendid keeper. Ready market in fine grain; of excellent flavor. Splendid keeper. Ready market in cts.; $1 \mathrm{~b}$., 85 cts.

\section{RUTABAGAS OR SWEDES}

Rutabagas require a longer season for maturing than turnips, hence should be sown earlier, about the middle of June.

American Purple Top-An old standard varlety. Large roots; yellow color with purple top. Fine quality and a good yielder. Packet, 7 cts.; oz., 12 cts.; 1/1 lb., 30 cts.; 1/2 lb., 50 ets.; lb., 90 cts.

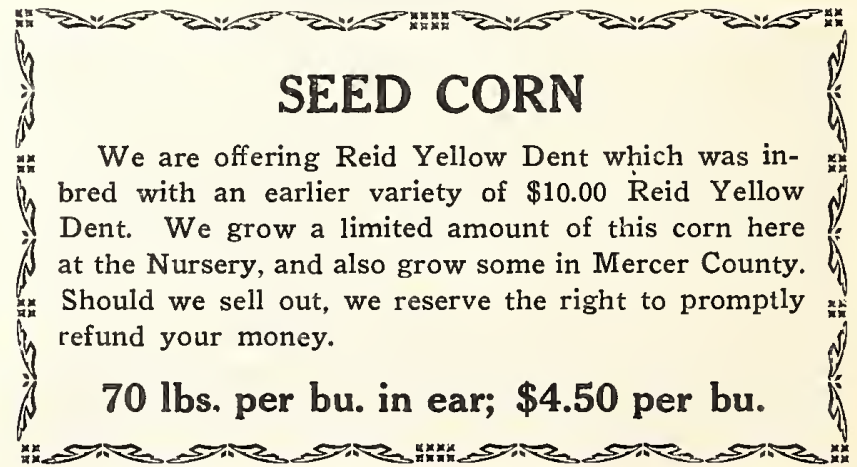




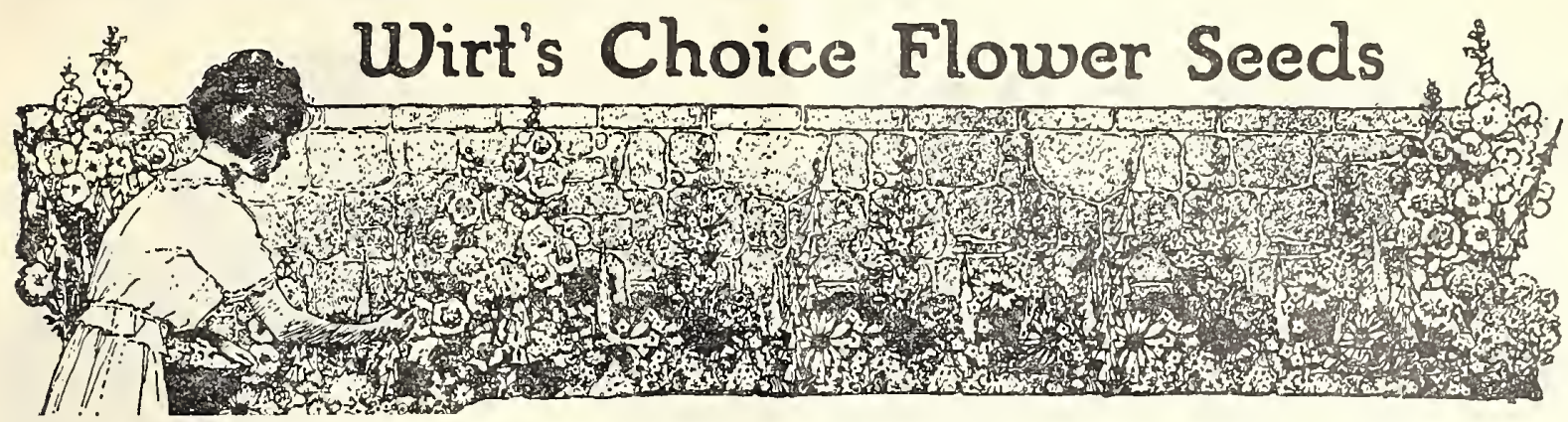

FLOWER SEEDS ARE SENT POSTPAID

Asters_-Asters are flowers of wondrous beauty. They are also light frosts. Seed can be sown outdoors as soon as the ground is warm and ary. Asters are being continually improved. The varieties listed below are beautiful. Everyone is worthy of a place in ties listed bour garden. Queen of the Market-Very early. Branching habit. Double flow-
ers, stems 12 to 15 inches long. Fine for cut flowers. Mixed colors. Packet, 10 ets.

Giant Comet-Mid-season. 18 to 24 inches high. The handsomest Aster of its type. Long twisted petals. Produces an abundance of large, beautiful flowers. Mixed colors. Packet, 10 ets.

Late Branching-Very beautiful flowers. Grows 2 to 3 feet high. Large deep double blossoms on long stems, Colors, mixed. Packet,

Sweet Alyssum_A dainty white flower. Delicate fraand to use in small bouquets. It is a standard variety. Nearly evcryone loves this refined little flower. There is a place in every garden for it Packet, 10 cts.

Balsam (Lady's Slipper) — One of the showiest anBrilliant double rose-like flowers often two inches across. Blooms Brilliant double rose-like flowers often two inches across. Blooms July to October. Do best in a rich loam and should have ample
moisture. They make beautiful table decorations. Flowers are borne moisture. They make beautiful table decorations. Flowers are borne
thickly on an erect bushy plant that grows 15 to 20 inches tall. Packet, 10 ets.

Calliopsis_- Very hardy and showy annual with bright yellow Easily grown and useful both for garden decoration and cutting. Sow early and thin to six inches apart. Mixed, Ilacket, 10 ets. Antirrhinum or Snapdragon_ Snapdragons are a everyone. Their beautiful colors and fragrance are wonderfully
pleasing. They are easily grown and are fine for cut flowers as well as a good bedding plant. Mixed. Packet, 10 ets.

Cosmos - The glory of the Fall garden. On tall, feathery, of lavender, pink and red. Ours is the early-blooming strain, that blooms from midsummer on. Mammoth Giant Mixed. All colors. Packet, 10 ets

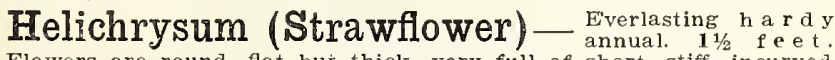
Flowers are round, flat but thick, very full of short, stiff, incurved petals surrounding a depressed center. Their chief value is for petals surrounding a depressed center. Their chier value is for about a third opened. Suspend bunch (heads down) in a cool, dry place until thoroughly dried. Mixed. Packet, $10 \mathrm{cts}$.

Larkspur_ Giant Hyacinth Flowered. 3 feet. Derives its ers to a double Hyacinth. Mixed colors. Packet, 10 ets.

Kochia-(Burning Bush or Summer Cypress), $21 / 2$ feet. The pact, and of a pleasing light green color. The plant may be grown singly or in the form of a hedge or background. In early Autumn the whole bush becomes carmine or blood-red and is called Burning Bush. Packet, 10 ets.

Lantana- Shrubbery plants with verbena-like flowers, in Marigold — The Marigolds are old favorites, frce-flowering with a glitter of yellow far into the frosts of Autumn. The African varieties produce large, self-colored blossoms on tall plants. The French are much smaller but the markings are very attractive. Double Dwarf, African-Mixed (Pride of the Garden), 15 inches, golden yellow flowers; dwarf habit. Packet, 10 cts.

Phlox Drummondi-The showiest and most easily raised rainbow are We variations or stripes, Veins duces such a continuous supply of the most of nothing which prowonderful range of colors. 112 inches high. Mixed. Packet, 10 cts.
Portulaca or Moss Rose- A beautipul hardy annual, by any other annual in cultivation. The plants are low-growing and creep along the ground. They thrive well in almost any location, even in a dry sunny place among stones, and can withstand the hot-
test summer weather. They like the full sunlight. Mixed. Packet, 10 cts.

Nasturtiums — They do just as well on poor soil as on rich soil. The climbing or trailing varieties are just the thing to covel a fence, stump or trellis. The dwarf varieties make a good border plant. All varieties are fine for cut flowers, Keep them picked. Dwarf Nasturtiums. Mixed. Packet, 10 cts. 'Tall or Climbing Varieties. Mixed. Packet, 10 ets.

Pansies - Miracle Mixed-Our super mixture contains all the cluding ruffled flowers and many of the new Sunburst Pansies; smoky rims, henna shades, with fine long stems. Here is something different and better in the Pansy world, Packet, 20 ets. eacli; 2 for 35 cts.

Petunias-Few plants equal the Petunias for freedom of handsome, sweet scented flowers in their delicate and gorgeous colors throughout the whole Summer.

SINGLE SMALL FLOWERING, 11/2 FEET Rosy Morn-Soft rose-pink with white throat; very dainty and one
of the most popular flowering plants in cultivation. I'acket, 15 cts.; 2 for 25 ets.

Mixed Singles, Packet, $10 \mathrm{ets}$

Double Flowered Mixed-Sure to produce a good percentage

double-flowering plants. Packet, 25 ets. LARGE SINGLE FLOWERING

Baleony Blue-Rich velvety indigo blue. Packet, 20 ets.

vixed Large Single. Packet, $15 \mathrm{cts}$.

Salvia_America or Globe of Fire-Continuous blooming, univaluable for bedding or planting in lines. Packet, 25 ets.

Verbena-A very popular garden annual. For beds and borundergrowth for tall plants.

Giant Double Flowered Zinnias- These most atare very popular. Remarkable for profusion and duration of flowers. A wonderful range of color, Old rose, dainty cream, brilliant ers. A wonderful range of color. Old rose, dainty cream, brilliant yellow, striking red, deep purple, and other lovely colo Giant-Flowering Show Zinnias-Huge flowers on long stems. Bright and pleasing colors. Produces remarkable effects. Be surc to have this attraction in your garden. Packet, 10c

\section{Sweet Peas- SUPREME SPENCERS}

King White-Large flowering. Glistening purlty of the whiteness and the perfect finish of the flower make this one of the best. Truly gigantic; very free bloomer. Packet, 10 ets; oz., 25 ets.

Blue Monareh-Dark blue. A splendid new dark blue of large size and free bloomer. Very rich in color. Packet, $10 \mathrm{cts.;}$ oz., 30 ets. King Edward-Deep rich crimson; a strong and beautiful color Does not fade. Packet, 10 ets.; oz., 30 cts.

Does not fade. Packet, 10 cts.; oz., 30 cts. Hereules-Deep pink. A magnificent soft ros-pink, ${ }^{2}$ requ

Spencer Mixed-All varieties. Packet, 10 cts.; oz., 20 cts.; 1/4 1b., 90 ets.

Poppies - Will grow and bloom in any kind of soil and in any showy that they attract more attention than anything on the place. Even in the heat of July, when nothing

Finest Mixed-Some of each kind. Double and single, tall and warf, and all color's. You can't beat it. Packet, 10 cts.

Scabiosa or Mourning Bride_- nual, which is once more decidedly in favor, is here offered in mixed colors. WonderfuI Cxtra Choice Mixed-Best large flowers. Packet, 10 ets. 


\section{GREENHOUSE DEPARTMENT}

A fine assortment of bedding stock, potted plants and cut flowers. Nearly all orders are sent parcel post, and postage must be included. Add $10 \%$ of the amount of your order for postage and any excess will be returned to you.

\section{Geraniums}

The best known and most used of all Bedding Plants S. A. Nut-(red), 4 in., 20c each; $\$ 2.20$ per doz. S. A. Nut-(red), $2 \frac{1}{4}$ in., 10 c each; $\$ 1.00$ per doz. Poitevine-(Salmon pink), 4 in., 25c each; $\$ 2.50$ per doz. Improved Poitevine-4 in., 30c each; $\$ 3.00$ per doz. Ivy Geranium-31/2 in., 20c each; $\$ 2.00$ per doz. Martha Washington -4 in., 30c each; $\$ 3.00$ per doz. 3 in., $20 \mathrm{c}$ each; $\$ 2.00$ per doz. Buchner-(white) 3 in. 20c each; $\$ 2.00$ per doz.

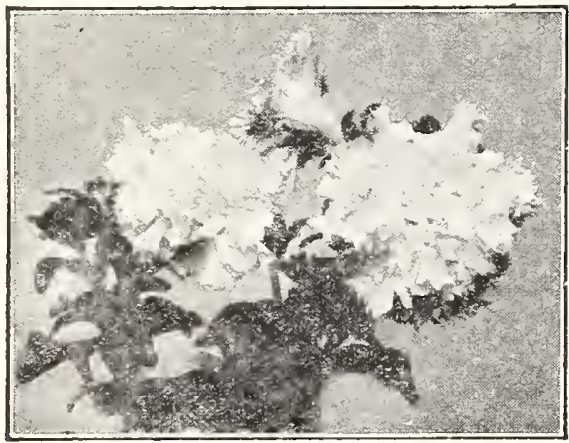

\section{Petunias}

Old time favorites, very fine for bedding, boxes, etc. Giant Double Ruffled, mixed, $15 \mathrm{c}$ each; $\$ 1.50$ per 12.

Giant Singles, mixed, 10c each; $\$ 1.00$ per 12.

Royal Purples-15c each; $\$ 1.50$ per doz.

Rosy Morns-(Pink), 10c each; 3 for 25c; 75c per doz.

\section{Snapdragons}

Snaps are popular Bedding plants with a great variety of colors. $10 \mathrm{c}$ each; $75 \mathrm{c}$ per 12 .

\section{Verbenia}

These are compact showy plants of great value for summer beds and porch boxes. Colors, purple, rose and white. 10c each; $\$ 1.00$ per doz.

\section{Summer Carnations}

Red, White and Pink. 10c each; $75 \mathrm{c}$ per doz.

\section{Asters}

Lavender, pink and white, 30c per doz.; 3 doz. for $75 \mathrm{c}$.

Space does not permit listing all the stock which I have. A trip to the Greenhouse is well worth your while, as I have many porch boxes and hanging baskets made up and can give you suggestions as to arrangement of plants both in them and your garden.

Drive up and select what you want.

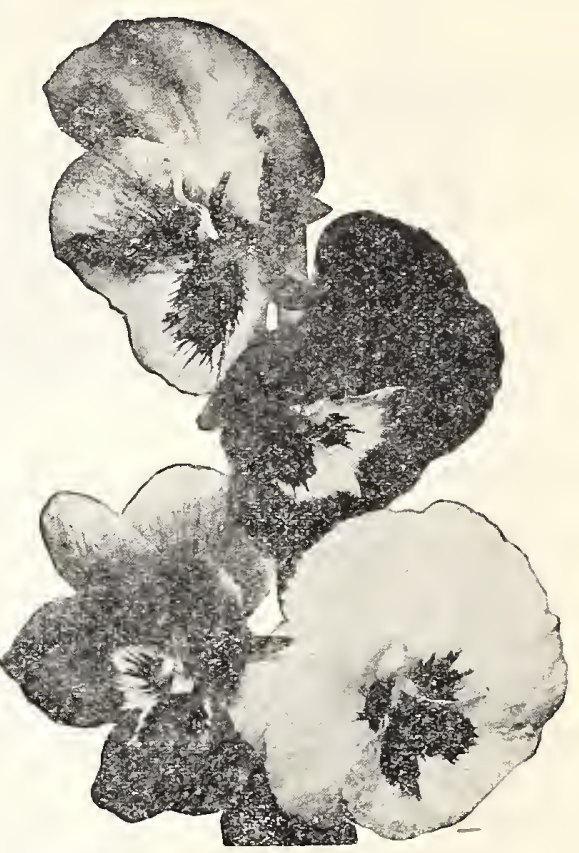

Pansies

Mixed Giant-Flowering kind 25c per doz.; 3 doz for $70 \mathrm{c}$.

\section{Drooping Vines}

Springerii Ferns-Fine for porch boxes and hanging baskets. 3 in., $15 \mathrm{c}$ each; 4 in., $25 \mathrm{c}$ each.

Parlor Ivy-15c each.

Wandering Jew-10c each.

Giant Jew-10c each.

\section{Vincas}

A much used vine for baskets and boxes. Variegated green and white foliage-also solid green. $15 \mathrm{c}$ each; $\$ 1.50$ per 12. 4 in. pots, $25 \mathrm{c}$ each; $\$ 2.50$ per 12.

\section{Hanging Baskets}

Filled with Ferns and plants, $\$ 1.25$ and up.

\section{Ageratum}

Useful in bedding also baskets as they supply the lack of blue shades among bedding plants. $10 \mathrm{c}$ each; $\$ 1.00$ per 12.

\section{Centurea (Dusty Miller)}

A very useful foliage plant with fern like foliage; dusted with silver to almost white. Fine for edging Cannas, Salvias, Geraniums, etc. 10c each; $\$ 1.00$ per 12 .

\section{Coleus}

Broad leaved bushy foliage plants. Unmatched for combination of color. Good for porch boxes, vases or bedding. Assorted colors, 10c each; $\$ 1.00$ per 12 .

\section{Salvia (Scarlet Sage)}

One of the showiest, cheapest and most practical red flowers for summer bed and border.

America-One of the finest varieties; grows $15 \mathrm{in}$. high; $10 \mathrm{c}$ each; 75c per 12 .

\section{Vegetable Plants}

Postage per doz., 4c; 2 to 4 doz., $6 c ; 4$ to 8 doz., $8 c ; 8$ to 12 doz., $10 \mathrm{c}$.

Cauliflower-25c per doz.

Peppers-(sweet and hot), 20c per doz.

Egg Plants-20c per doz.

Early and Late Cabbage-10c per doz.

Tomatoes-Earliana, Ponderoso, Stone and Beefsteak, 10c per doz.

Celery-50c per 100 
Use This Side for NURSERY STOCK

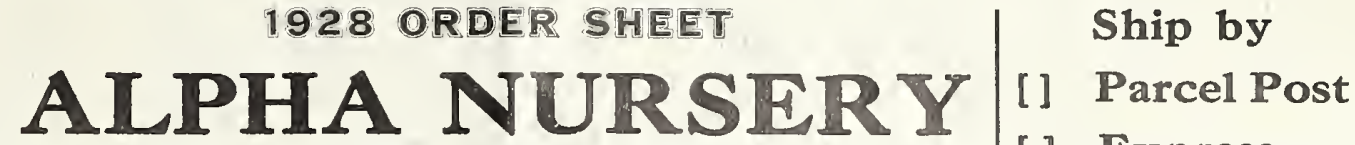 ALPHA, ILLINOIS \\ H. G. WIRT, Proprietor \\ [1 Express \\ [] Freight}

Ship to

Date

Street

City

P. O. Address

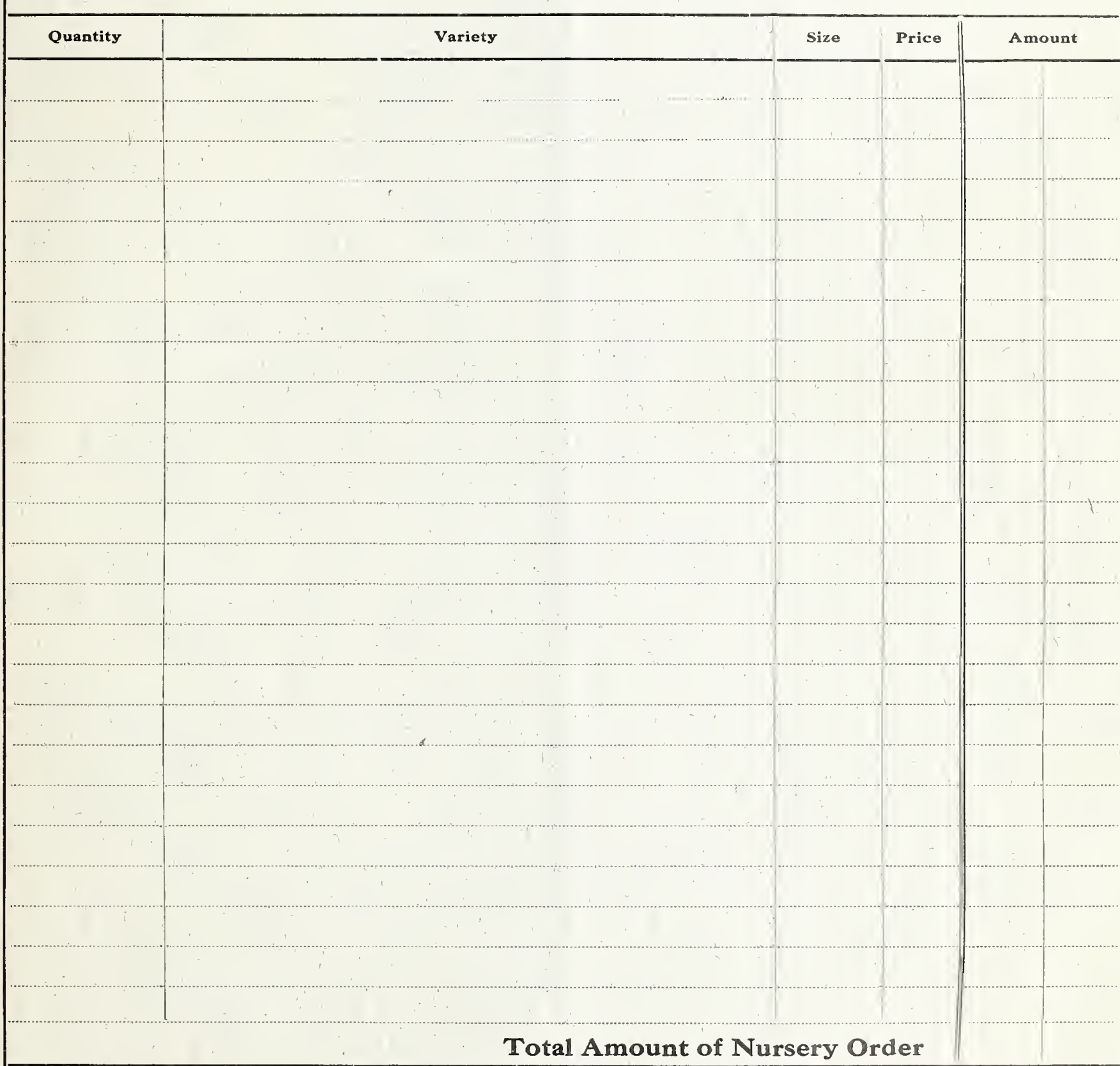




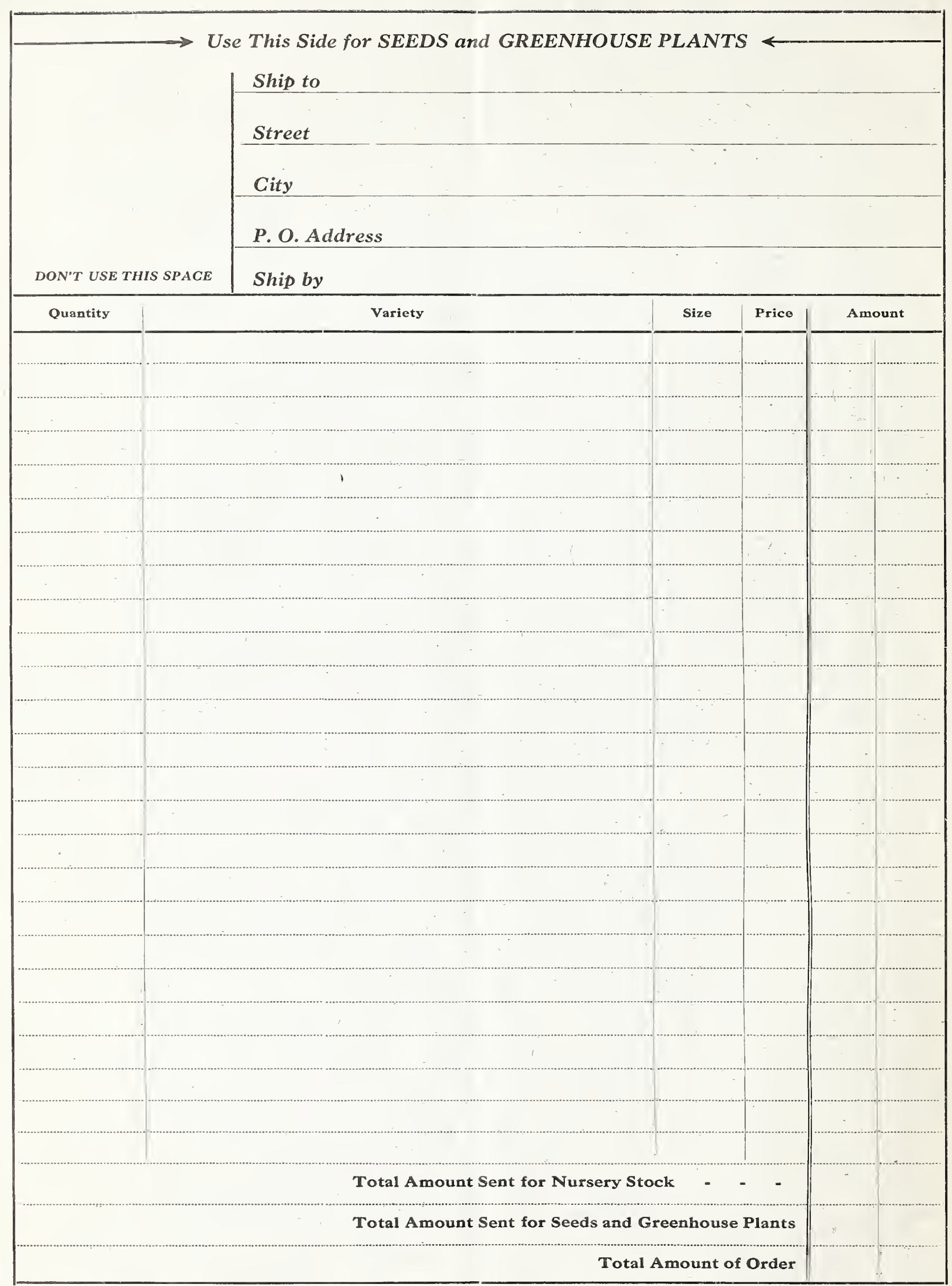




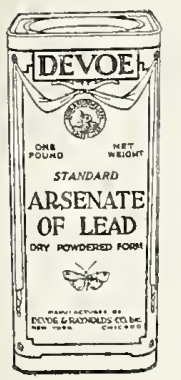

Arsenate of Lead

Use this spray for leaf eating in sect $\mathrm{s}$, apple worm (coddling moth), and all kinds of worms that affect trees, plants, shrubs, and vegetables during the summer.

For Apples-1st spray just before the blossoms open. 2nd spray when blossoms are two-thirds off. This is the most important spray for Codling Moth. 3rd spray about two weeks after $/ \mathrm{sec}$ ond spray. 4th spray about August. Use three to four first week in August. Use three to four tablespoons to one gad to 50 gallons of water. lbs. Arsenate of Lead plum and Cherry. use For Peach, Pear, stum and the last two are the first and second spray, the last two are unnecessary. (Use same proportion as above.) For small fruits, vegetables, etc. Spray when the plants show sign of insect attack Use same proportion as above.

$$
\begin{array}{rll}
\text { Prices- } 1 & \mathrm{lb} \text {. can } \$ .50 \\
4 & \mathrm{lb} \text {. can } \$ 1.75 \\
10 & \mathrm{lb} \text {. can } \$ 4.25
\end{array}
$$

By express only or with express shipment of Nursery Stock.

order early and be ready to spray at proper time.

Lime Sulfur

Use Lime Sulfur to control San Jose and other Scale. Apple Scab, Peach Leaf Curl and Brown Rot of Cherries and Plums.

For dormant sprayuse ten to fourteen lbs, to 50 gallons of water. Smaller quan. tities 12 to 18 tablespoons to one gallon of water. Apply to Apple, Pear, Peach, Plum and Cherry while buds are swelling and before any leaves are out. (Do not use this proportion when leaves are out as it will kill them).

For summer spray-apply when the leaves start, repeat every 10 to 15 days until blossoms appear. Use two tablespoons Lime Sulfur and six tablespoons Hydrated Lime to fur gallon water or $3 \mathrm{lbs}$. Lime Sulfur and one gallon water or 3 lbs. Lime sulfur and For all stone and seed fruits except Peach which do not need it.

$$
\begin{array}{rll}
\text { Prices- } 1 & \mathrm{lb} . \text { can } \\
5 & \mathrm{lb} \text {. can } \$ 1.25 \\
50 & \mathrm{lb} \text {. can } \$ 8.00
\end{array}
$$

By express only; can be sent with express shipment of Nursery Stock.

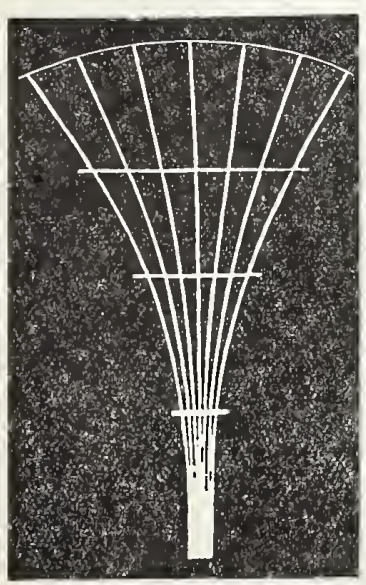

\section{SPRAY YOUR TREES}

Spraying is necessary to have good, clean, large fruit. There are three main considerations in spraying: an effective spraying machine, knowledge of the proper time to spray, and the use of the best quality of material to defeat the enemy.

The principle underlying spraying, is to cover the foliage or wood of plants with a medium the fungus will not grow, or which will kill the leaf eating insects.

Promptness is the main factor in spraying and most important.

The material we offer is the best in quality we can buy, therefore the prices are a little higher than a cheaper grade of material can be sold for.

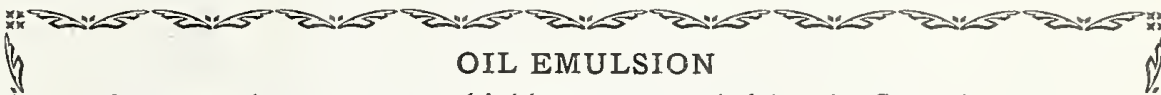

Is a new dormant spray, highly recommended by the State for the control of San Jose scale. It sure does the business, cleans up your trees. February is a good month to use it.

1 It was developed by the U. S. Government Experiment Station where tests show that it is 98 to $99 \mathrm{r} / 2 \%$ effective against San Jose scale. It is applied while the trees are dormant, that is, while the leaves are off. Where applied as a late spring spray is effective in controlling Aphids. It is used at 3 the rate of three gallons of Emulsion per hundred gallons water, and where scale infestation is serious up to four and one-half gallons per hundred water.

Oil Emulsion sprays are not caustic, non-corrosive, and they do not burn the eyes and hands as does the Lime Sulphur material.

Lime Sulphur, according to Government tests, is only $85 \%$ efficient as 1 compared with $98 \%$ for Emulsion.

Prices-5 gal. can, $\$ 3.25$ by Express; 1 gal. can, $\$ 1.00$; postage, $20 \mathrm{c}$.

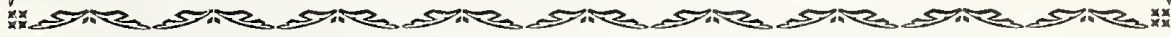

\section{GOOD SPRAY PUMPS}

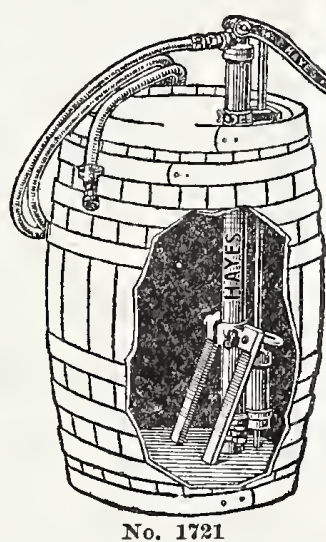

No. 1721

\section{HAYES BARREL SPRAY PUMPS} Nos. 172 and 1721

This type of spray pump can be mounted on the end of the barrel only, where it bolts to the chime. with an adjustable clamp. This permits the pump to anchor firmly to the bottom of the barrel and allows the pump to be used in any length barrel.

No 172 Pump only with agitators fitted for $1 / 2-i n$. Wo. 172 Pump only with agitat

hose connection. Weight $31 / 2$ pound No. 1721 Barrel Sprayer with $121 / 2-\mathrm{ft}$., $1 / 2-1$., Stayon fittings, agitator, and Hayes dise strainer nozzle, weight
$\mathbf{3 6}$ lbs.; does not include barrel. \$14.00 each. Must go by express or freight.

\section{HAYES HAND BUCKET SPRAYERS}

No. 211

Handiest of all tools around the house, farm and garden. The modern home can find some use for Hayes Hand Bucket Sprayer each and every day. Sprays trees, small fruits, garden truck and flowers. Disinfects farm buildings, poultry houses, hog houses. Sprays cattle with fly oil and stock dip. Can be used for killing lice on poultry, white washing butldings and fences, washing windows and in a dozen and one other ways around any home.

All working parts are brass. They will not corrode. Solid brass ball valves. Malleable iron, non-breakable foot rests. Complete, with hose, \$1.25. Postage, 30c extra.

\section{ACME KNAPSACK COMPRESSED AIR SPRAYER}

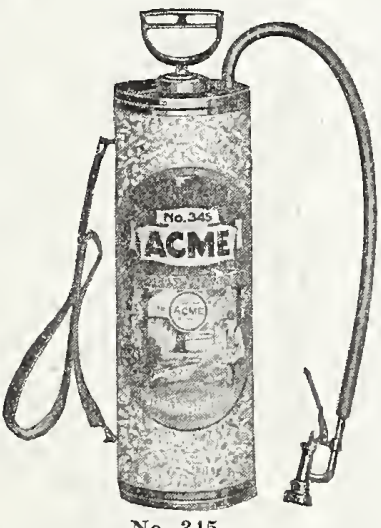

Long lasting. Has rust resisting galvanized iron tank. Simple in construction, strong, yet light in weight. Tank measures 20 inches high, 7 inches in diameter and holds four gallons. Tested to 60 pounds air pressure.

Nozzle is made from solid brass, produces a fog-like spray and will not corrode. Spring handle opens and closes the nozzle outlet.

This sprayer will not clog, handles all solutions successfully and gives perfect satisfaction in spraying crops, fruits,

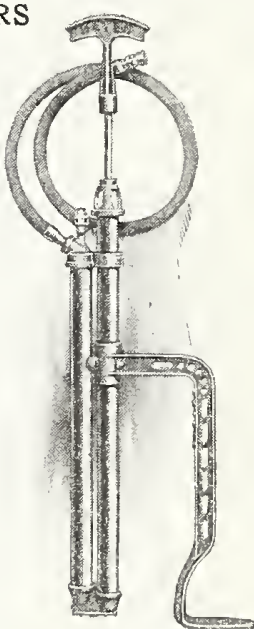

No. 211 shrubs, flowers, disinfecting poultry houses and cattle sheds and spraying cattle with fiy oil. Can be carried with the top handle or the shoulder straps.

\section{REGULAR SPECIFICATIONS}

No, 345 Compressed Air sprayer, 4-gallon size, galvanized tank, with hose and nozzle. Weight, 10 pounds, $\$ 6,00$ each. Postage, 30e.

Order Early-Be ready for Spring Spraying

Send for Prices on Large Sprayers 
Rlpha Nursery

H. G. Wirt, Proprietor Alpha, Illinois

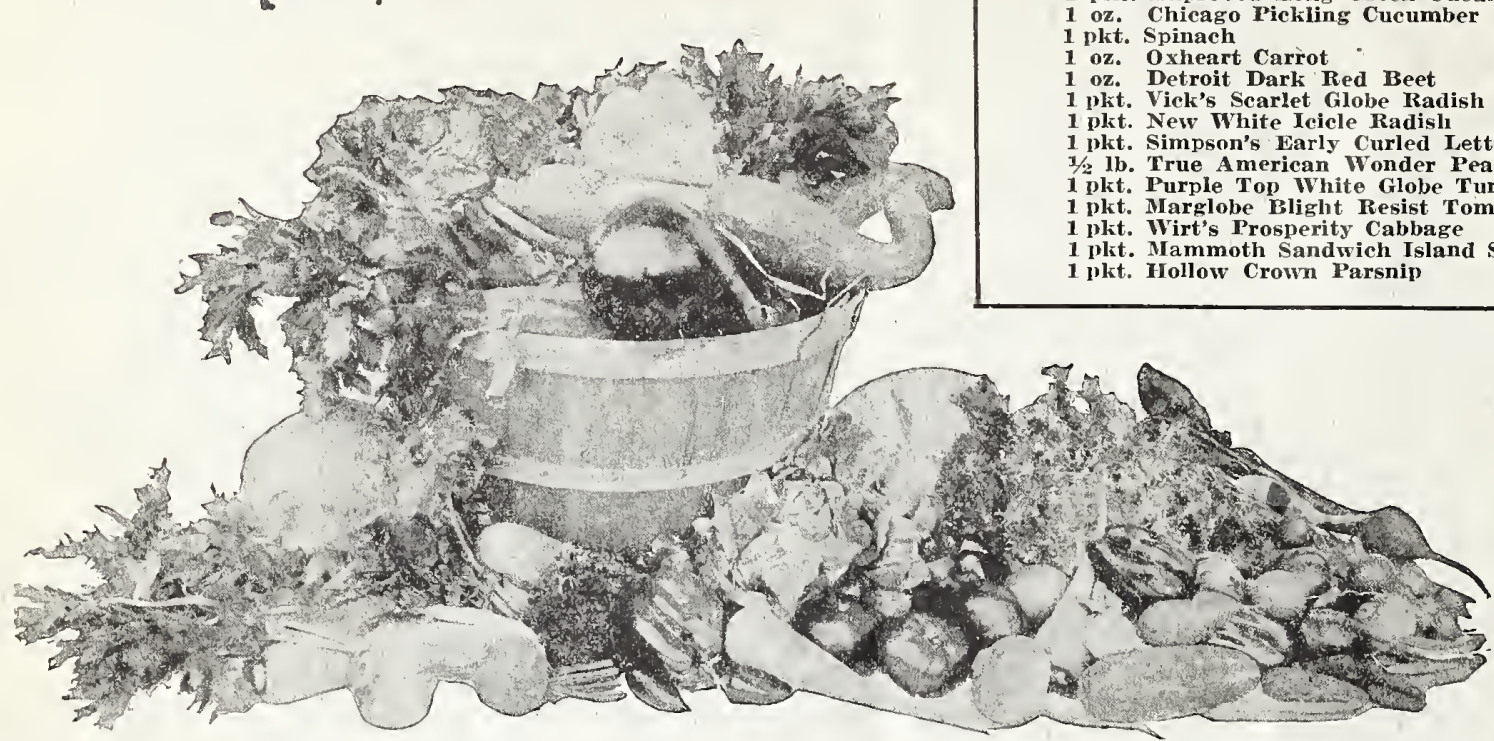

$1 / 2$ lb. Golden Bantam Sweet Corn
WIRT'S BARGAIN GARDEN SEED COLLECTION

A collection of standard seeds for the Home Garden

1/2 Ib. Giant Stringless Green Pod Beans

1/2 1b. Wirt's Rust Proof Golden Wax Beans

1 plit. Improved Long Green Cucumber

1 oz. Chicago Pickling Cucumber

1 pkt. Spinach

oz. Oxheart Carrot

oz. Detroit Dark Red Beet

plit. Vick's Scarlet Globe Radis

pkt. Simpson's Early Curled Lettuc

lb. True American Wonder Peas

pop White Globe Turnip

plit. Virt's Prosperity Cabbage

plit. Mammoth Sandwich Island Salsify

pkt. Hollow Crown Parsnip

\section{SEEDS OF HARDY PERENNIAL FLOWERS}

There are a few perennials that will bloom the first year from seed if planted early. The Delphiniums are almost certain to bloom the first year, But if you will plant perennial seed this spring you will have hundreds of plants by fall. Transplant these plants in the fall or spring. It is best to sow the seed in rows 4 to 6 inches apart and thin in the row. If you do not care to spend the time waiting for plants from seed, we list a good assortment of the best perennial plants on pages 18 to 22 in this catalogue.

\section{THE FOLLOWING SEEDS ARE ALL SENT POSTPAID}

AQUILAGIA OR COLUMBINE-An early blooming plant. Flowers well above foliage with long, graceful stems. Suitable for bedding or for cut flowers. Mixed Varieties, 10c pkt.

BABY'S BREATII or GYPSOPHILA-The fine cut, white blossoms are beautiful while fresh, or when dried as everlastings are indispensable in winter bouquets. Plit. 10c.

CAMPANULA- (Canterbury Bells). The well known "Cup and Saucer" plant. Pink, blue and lavender bells; half as large as a teacup. Mixed colors. Pkt. 10c.

DAISIES, SHASTA, White. The well known large-flowering white Daisy, which was introduced from California. Pkt., 10c.

COREOPsis Lanceolata-A yellow daisy-shaped flower. This plant, with Gaillardia, are the two perennials that best stand hot, sunny locations. Pkt., 10c.

GAILLARDIA-(Blanket Flower). A very useful perennial for the hot, sunny locations. Color a blending of orange-yellow and various shades of red. Very useful as a cut flower, as it blooms all summer. Pkt., 10 cts.

HoLLYHOCKS-Tall, stately old favorite; given plenty of room will make a wonderful showing during July. A splendid background for a flower garden and shows up well along the fence or ground for a flower garden and shows up well along
grouped beside the house. Double Mixed. Pl., 10c.

PYRETHRUM roseum-(Painted Daisy). One of the newer perennials, but already so popular that some growers are making a specialty of it. The blossom is daisy-shaped and comes in all the colors of pink, white and rose. It is always in bloom at Decoration Day, and combines beautifully with Peonies, as it is the same shade. You can't have too many. Mixed colors. Pkt., 10c.

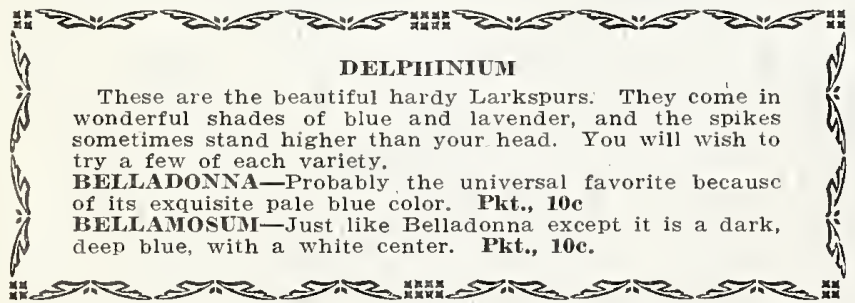

LATHYRUS or PERENNIAL SWEET PEA-A sturdy and rapid growing vine, which is covered all through the late summer with masscs of Sweet Pea-shaped flowers in white, pink or rose. Mixed colors. Pkt., 10e.

VIOLA-(Tufted Pansy). This is the Pansy with small blossoms that self-sows among your shrubbery, and is sometimes called "Heartease." Mixed colors, Pht., 10c.

\section{Wild Flower Garden}

WIRT'S SPECIAL MIXTURE-This is a complete mixture of easily grown annuals which have proven to do well and bloom freely under widely different conditions of soil and weather. The Wild Flower Garden Mixture includes a wide range of varieties and colors. It is sure to give a fine display with a minimum of care. Packet, 10 cts.; $0 z, 30$ cts.

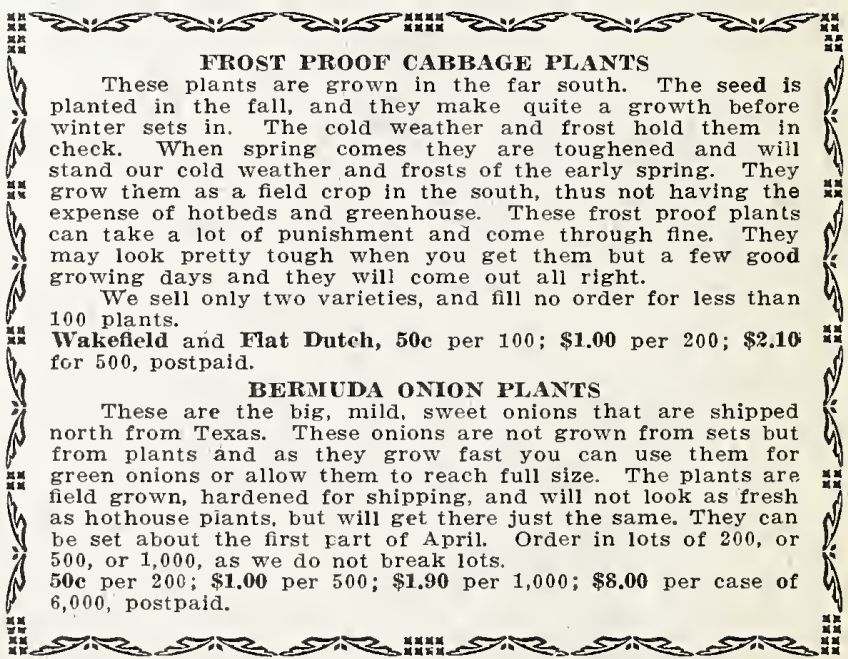

Six Packets Your Selection, 55c, or 12 Packets, One of Each of the Above Varieties, $\$ 1.00$. 